\title{
A Field Guide to Industrial Properties in Texas
}

Amy E. Dase

Follow this and additional works at: https://scholarworks.sfasu.edu/ita

Part of the American Material Culture Commons, Archaeological Anthropology Commons, Environmental Studies Commons, Other American Studies Commons, Other Arts and Humanities Commons, Other History of Art, Architecture, and Archaeology Commons, and the United States History Commons

Tell us how this article helped you.

This Article is brought to you for free and open access by the Center for Regional Heritage Research at SFA ScholarWorks. It has been accepted for inclusion in Index of Texas Archaeology: Open Access Gray Literature from the Lone Star State by an authorized editor of SFA ScholarWorks. For more information, please contact cdsscholarworks@sfasu.edu. 


\section{A Field Guide to Industrial Properties in Texas}

\section{Licensing Statement}

This is a work produced for the Texas Department of Transportation (TxDOT) by the report producer. TxDOT and the report producer jointly own all rights, title, and interest in and to all intellectual property developed under TXDOT's contract with the report producer. The report may be cited and brief passages from this publication may be reproduced without permission provided that credit is given to both TxDOT and the report producer. Permission to reprint an entire chapter, section, figures or tables must be obtained in advance from either the Supervisor of the Archeological Studies Branch, Environmental Affairs Division, Texas Department of Transportation, 125 East 11th Street, Austin, Texas, 78701 or from the report producer. 


\title{
A Field Guide to Industrial Properties IN TEXAS
}

\author{
by
}

Amy E. Dase

Prepared for

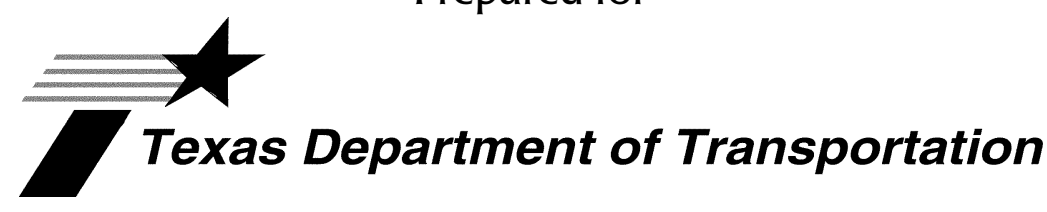

Environmental Affairs Division

HISTORICAL STUDIES REPORT NO. 2003-01

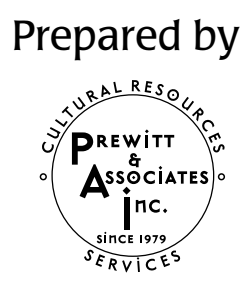

Prewitt and Associates, Inc.

Cultural Resources Services

Austin, Texas

REPORTS OF INVESTIGATIONS, NUMBER 137

May 2003 


\title{
A Field Guide to Industrial Properties IN TEXAS
}

\author{
Copyright $\odot 2003$ \\ by the Texas Department of Transportation (TxDOT)
}

All rights reserved.

TxDOT owns all rights, title, and interest in and to all data and other information developed for this project under Contract \#572XXSA005. Brief passages from this publication may be reproduced without permission provided that credit is given to TxDOT and the author.

Permission to reprint an entire chapter, section, figures, or tables must be obtained in advance from the Supervisor of the Historical Studies Branch, Environmental Affairs Division, Texas

Department of Transportation, 125 East $11^{\text {th }}$ Street, Austin, Texas 78701. Copies of this publication have been deposited with the Texas State Library in compliance with the State Depository requirements.

Printed by Morgan Printing in Austin, Texas

May 2003

For further information on this and other TxDOT Historical Studies publications, please contact

Texas Department of Transportation

Environmental Affairs Division

Historical Studies Branch

Lisa J. Hart, Supervisor

Historical Studies Report No. 2003-01

Bruce D. Jensen, Series Editor

Production of this report was directed by

Prewitt and Associates, Inc.

Cultural Resources Services

Austin, Texas

Reports of Investigations, No. 137

ISBN 1-930788-50-9 


\section{Table of Contents}

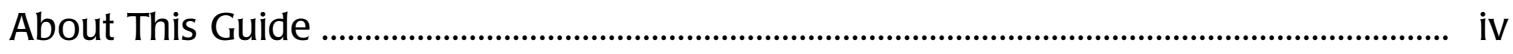

How to Use This Guide ......................................................................................................... v

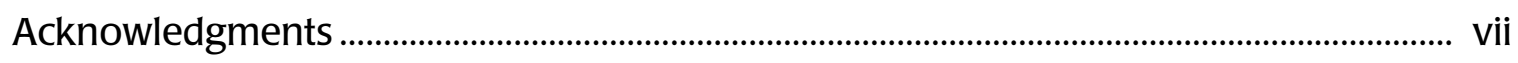

Petroleum and Natural Gas Property Types ..................................................................... 1

Bulk Terminal Plants ....................................................................................................... 3

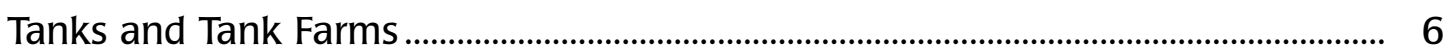

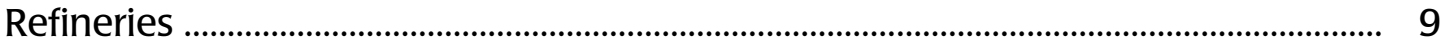

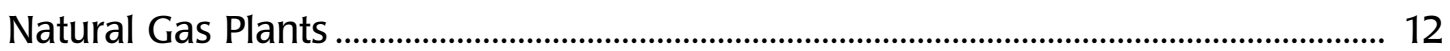

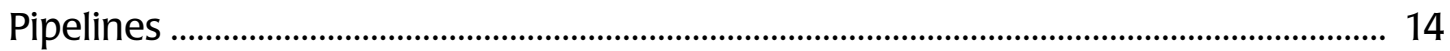

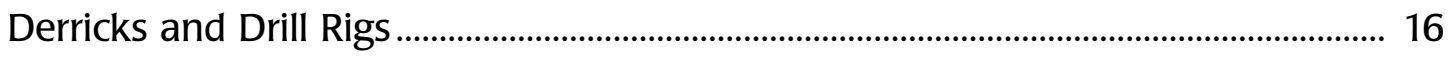

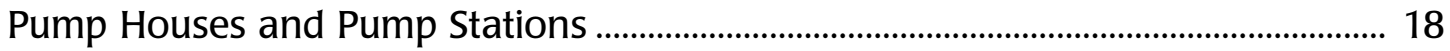

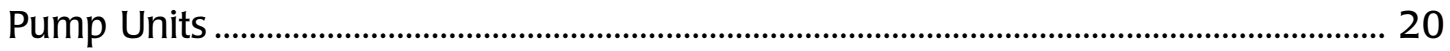

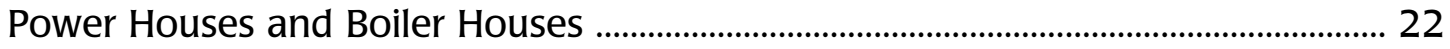

Separators and Metering Stations .......................................................................................... 24

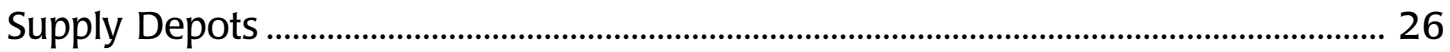

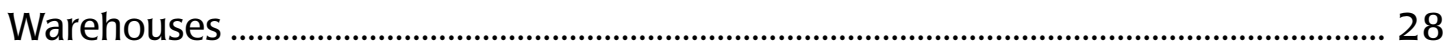

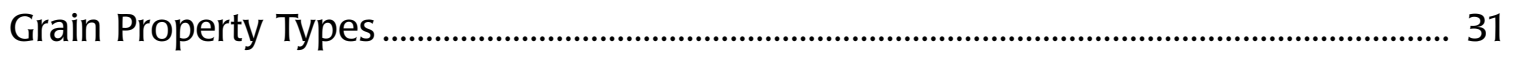

Storage Complexes ................................................................................................................. 32

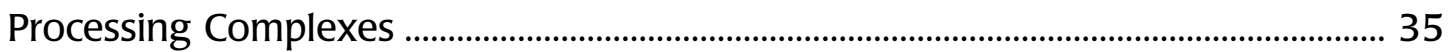

Auxiliary Buildings ................................................................................................................ 38

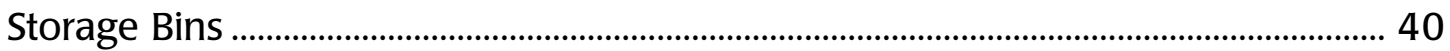

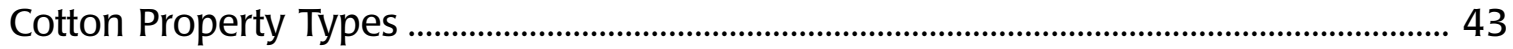

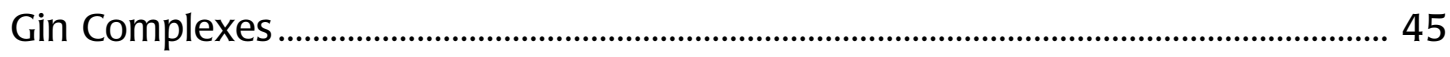

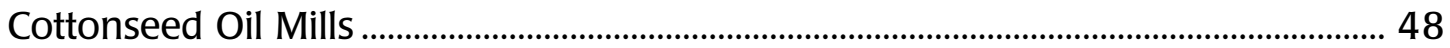

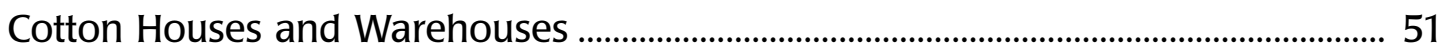

Seed Storage Facilities ............................................................................................................. 54

Trash Collection Facilities......................................................................................... 56

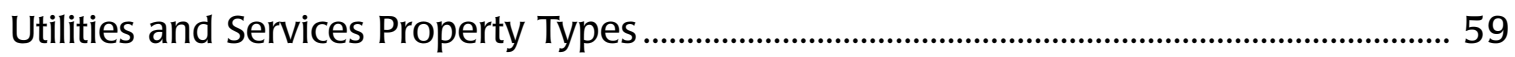

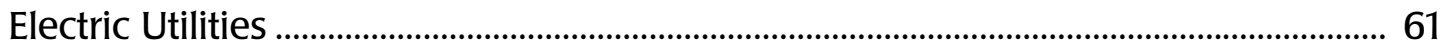

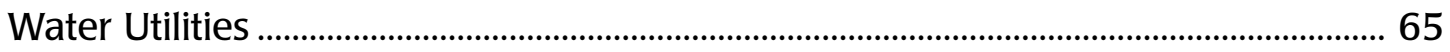

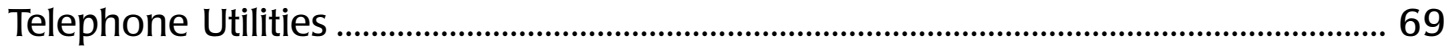

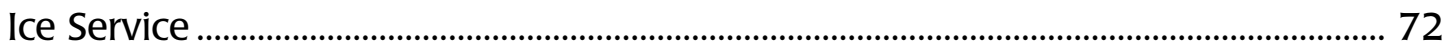

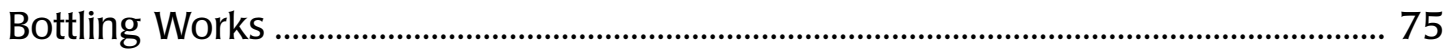

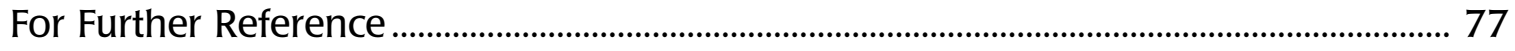

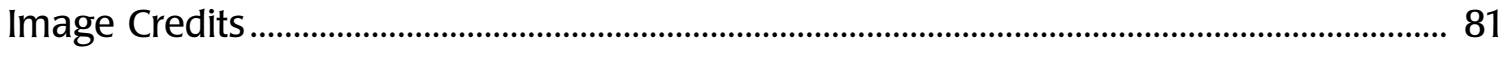




\section{About This Guide}

In the truest sense, industrial properties are more likely than any others to fit architect Louis Sullivan's oftquoted assertion that "form ever follows function." Despite their substantial role in economic and social spheres, industrial properties have long been glossed over by those interested in material culture. It seems, in fact, that neither a comprehensive nor a contemporary overview of these property typologies has been accomplished to date.

A Field Guide to Industrial Properties in Texas is an attempt to address an identifiable information gap. It takes into consideration industrial properties that are related to the petroleum and natural gas, grain, cotton, and utilities and services industries. These seem to be the most understudied sectors, which have few modernday interpretive studies and lack any clear synthesis in the secondary literature.

The primary goals of this publication are three-fold. The first objective is to synthesize and impart information about these property types. The second aim is to give the Texas Department of Transportation a tool that will help staff identify and classify industrial buildings and structures. Thirdly, it will aid in evaluating properties for eligibility in the National Register of Historic Places.

This illustrated field guide is one of two publications produced by Prewitt and Associates, Inc., for the Texas Department of Transportation, Environmental Affairs Division, describing the history and architectural resources of the U.S. Highway 277 corridor from Wichita Falls to Abilene, Texas (under Contract \#572XXSA005, Work Authorization \#57204SA005). The second report, which was prepared by Martha Doty Freeman concurrently with this field guide, is entitled The Development of an Agricultural Landscape along a Portion of the U.S. Highway 277 Corridor, with a Case Study of the Cotton Industry in Haskell, Texas. It contains three main parts: a broad historic overview of the corridor focused on railroad construction and development of an agricultural landscape; a historical case study of Haskell, Texas, centered on the local cotton industry and briefly describing cotton-related cultural properties; and an annotated bibliography.

The project parameters delineated certain limitations for this publication. One significant constraint was that images had to be acquired from secondary sources. Because of this, some images are not as clear as original photographs, drawings, or footprints would be. The focus of the images was limited to industrial buildings and structures, rather than the equipment and machinery they housed. Emphasis is on properties constructed from the late nineteenth century through the 1950s, and does not take into consideration mid-nineteenth- or latetwentieth-century buildings or structures. Although many industrial complexes included corresponding housing facilities for workers, residential property types are not discussed. Since the project was based on industrial properties along the U.S. Highway 277 corridor between Wichita Falls and Abilene, the initial research pertained specifically to that area. As a result, many of the sources and images are from that region of the state, which was intended to serve as a representative cross-section. However, the broader applications of this field guide were taken into account and its usefulness generally pertains to industrial properties statewide. 


\section{How to Use This Guide}

This field guide is a tool for identifying industrial properties in Texas and for making eligibility recommendations to the National Register of Historic Places. The sections in this field guide describe each of four major types of industrial properties that are common to Texas: petroleum and natural gas, grain, cotton, and utilities and services. Within each section are several typologies with lists of character-defining features and principal subtypes, as well as a comments section. More than 160 images illustrating representative examples of industrial buildings and structures are included. The images reveal scale, shape, mass, proportion, rhythm, articulation, decorative details, and materials.

Challenged with an unidentified industrial property, the reader should begin by trying to determine the function of the property in question. Is the property related to petroleum and natural gas, cotton, grain, or utilities and services? The reader should then thumb through the images within that industry to find properties similar to the building or structure in question. In doing so, it is important to note the dominant character-defining features such as plan, roof form, and materials. When an image similar to the unidentified property is discovered, the secondary features such as constituent parts, location, and smaller details like signage and architectural details will further assist in identification.

To be potentially eligible for the National Register of Historic Places, buildings and structures must retain most of their character-defining features as listed within each property type. Potentially eligible properties should generally retain those features that are particular to their subtype. The comments section briefly describes the function of the subtype. It also provides information that could be used to justify a property's significance as a good example of its type. In many cases this explanation must be considered within the context of local history. Eligible properties, as well, should retain a relatively high degree of integrity of location, design, setting, workmanship, materials, feeling, and association. More details about the National Register of Historic Places are available from the Texas Historical Commission and the National Park Service.

The field guide focuses on building and structure exteriors. The exteriors of industrial properties categorically convey function, form, proportion, detail, material, and construction. Utilitarian by necessity, only a few industrial property types bear anything resembling traditional decorative ornamentation similar to that which adorns residential and commercial properties. Those industrial buildings that exhibit such detailing usually include public reception areas in a complex, such as those an office building at a bulk terminal plant.

This lack of traditional stylistic embellishment reflects a standardized, pre-fabricated design aesthetic that characterized the American engineered landscape from the late nineteenth through the twentieth centuries. Those engineers, industrial planners, and architects who designed function-driven properties claimed kinship with the foremost architectural thinkers of the time. They worshipped functionalism, loved flat, bare surfaces, decried formal ornamental schemes, and were enthralled with new building materials. Indeed, several architectural critics pointed to the massive concrete cylindrical towers of Midwestern grain terminals as a harbinger of the new design epoch. Rarely were these grand concepts translated into the oil fields and cotton gins of Texas. These properties, however, were exemplary of emerging American industrial design.

For some industrial properties, internal components can be helpful in their identification. Certain specialized interior rooms or machinery and equipment, if extant, could be useful to identifying a property type. The internal equipment particular to a feed mill as compared to that of a flour mill, for instance, will help in distinguishing among the grain-processing complex subtypes.

The construction dates of some industrial buildings and structures can be pinpointed, although it is difficult to be exact in many cases. This is due to the nature of industrial properties, which regularly instituted changes as technology progressed. The introduction of new or used machinery or building parts was common. A cotton gin, for example, may have had state-of-the-art equipment housed in an older, two-story gin house. Derricks and 
drill rigs — common to the petroleum and natural gas industry — were bought, sold, and moved to new locations regularly after pump units had been set up. Pump units, as well, were relocated when a well stopped producing. Alterations to industrial properties, such as additions to electric generating plants or water filtration systems as the population grew, are common. Thus, an industrial complex expands or contracts, depending on the availability of either raw materials to be processed, technology, or both. Typically dates of construction for a complex will span a relatively long period, potentially from the late nineteenth through the mid-twentieth centuries and sometimes beyond.

Property types will have regional and local variations. These deviations can be based on a number of possible factors, including construction date, available materials, community size, and the builder's level of expertise. All of these factors, in turn, are based on local conditions. Petroleum discoveries in East and Southeast Texas at the turn of the century indicate early dates of construction and the use of locally available lumber. By the late 1910s, wells discovered at Burkburnett and Wichita Falls, and later in the Permian Basin, indicate contemporaneous dates of construction and the use of metal construction. Likewise, grain storage facilities in small towns would suggest the need for small-scale country elevators, while those in a major transportation center would necessitate large-scale terminal elevators.

In larger communities or where corporations were involved, industrial properties were more likely to be designed and constructed by a trained architect or engineer. These professionals would bring particular design skills to the fore in planning and arranging industrial complexes, such as cottonseed oil mills or sewage treatment plants. In the ubiquitous small towns that dot the Texas countryside, however, local craftsman and builders were responsible for building industrial properties, such as feed mill elevators, ice service stations, and warehouses. Industrial properties in these communities were less likely to be influenced by standardized corporate design preferences. Exceptions to this are properties associated with petroleum and natural gas, which, by the 1910s, had fully developed composite catalogs of every imaginable type of building, structure, machine, or equipment necessary to any aspect of the industry. Entrepreneurs ordered the requisite materials, had them shipped to a supply depot, and assembled them on site. This was true to some degree in the cotton industry as well, since gin manufacturers sold all constituent parts of the ginning process, including gin houses and seed houses. With the exception of gin stands and other specialized equipment, ginners were as likely to scavenge buildings from failed businesses and employ them in their own operations than to buy completely new buildings, especially in later years as the number of gin complexes declined.

Identifying the character-defining features common to industrial properties allows the reader to first recognize the compositional vocabulary that defines these typologies. The reader can then define the local artisanry, setting, history, and entrepreneurial spirit specific to each industrial property. With these tools, the reader has basic information from which to make recommendations for eligibility in the National Register of Historic Places. 


\section{Acknowledgments}

Production of this field guide depended heavily on the skills of several individuals. Ross C. Fields, president of Prewitt and Associates, Inc., provided philosophical guidance and an objective opinion. Brian J. Wootan scanned and manipulated the many illustrations presented herein. Audra L. Pineda and Sandra L. Hannum conceptualized the presentation of the contents. Mr. Fields and Ms. Pineda edited and Ms. Hannum produced the field guide.

Special thanks go to Martha Doty Freeman, consulting historian with Prewitt and Associates, Inc.; Bruce Jensen with the Environmental Affairs Division of the Texas Department of Transportation; and Bob Brinkman with the History Programs Division of the Texas Historical Commission. In the earliest planning stages of the project, these individuals had the foresight to step beyond traditional boundaries of developing historic contexts. They creatively endeavored to shape this field guide with the potential for wide-ranging practical applications. Credit also goes to Joe C. Freeman and Diane E. Williams, whose earlier works contributed to devising this field guide. Carroll Van West of the Center for Historic Preservation at Middle Tennessee State University willingly provided thoughtful critique, without remuneration, and this work is all the better for his evaluation and comments.

Several institutions provided materials for this publication that were critical to its production. The bulk of materials was collected from the Perry Castañeda Library, The Center for American History, the Walter Geology Library, the Architecture and Planning Library, the Mallet Chemistry Library, the Undergraduate Library, and the McKinney Engineering Library all at The University of Texas at Austin. Other sources include the Dallas Public Library, the Southwest Collection at Texas Tech University, the Petroleum Museum in Midland, and publications of the Sanborn Map Company (available online through TexShare and many public libraries). Carol Roark, manager of the Texas/Dallas History and Archives Division with the Dallas Public Library, and Todd Houck, Director of Archives at the Petroleum Museum, were especially helpful in finding images of industrial buildings and structures. The Handbook of Texas (available online at "www.tsha.utexas.edu/handbook/online/") provided relevant information on general aspects of the petroleum and natural gas, grain, cotton, and utilities industries.

Particular appreciation is owed to the many scholars and interested individuals who have sought to describe, document, and interpret industrial properties. Their many publications are credited in both the "For Further Reference" and "Image Credits" sections. Their efforts made this opportunity to synthesize information about industrial property types possible. 



\section{Petroleum and Natural Gas Property Types}

The earliest successful oil field in Texas opened in 1898 in Corsicana and peaked two years later. On its heels, the Spindletop oil field opened in 1901, climaxed the following year, and diminished until new drilling methods made the field productive again. Other significant finds along the Gulf Coast were the Sour Lake, Batson-Old, Humble, and Goose Creek fields. These also flourished briefly, but managed to feed several refineries and move crude and refined products along an expanding pipeline system. In the 1910s, North Texas developed boomtowns around the Burk, lowa Park, and the Wichita County Regular fields. Even larger discoveries were at Ranger, Burkburnett, and Desdemona. The following decade uncovered fields in Archer, Coleman, Young, Eastland, Stephens, and Shackelford Counties. In Central Texas fields were found at Mexia, Currie, Deep Powell, Wortham, and Richland in the 1920s. The Texas Panhandle region had several wells producing by the 1920s, with major discoveries in Borger and parts of Hutchinson and Carson Counties. Southwest Texas discoveries began early in the twentieth century and had substantial natural gas production. The Permian Basin achieved significant oil production in the mid-1920s and had several important discoveries, including the Big Lake, Howard-Glasscock, McCamey, East Howard-latan, Yates, Hendrick, Kermit, North Ward-Estes, and Fuhrman-Mascho fields. The last region of the state to successfully produce oil was East Texas. In the 1930s the huge East Texas oil field, which covered parts of five counties, was opened.

The industry thrived on extracting and processing these valu-

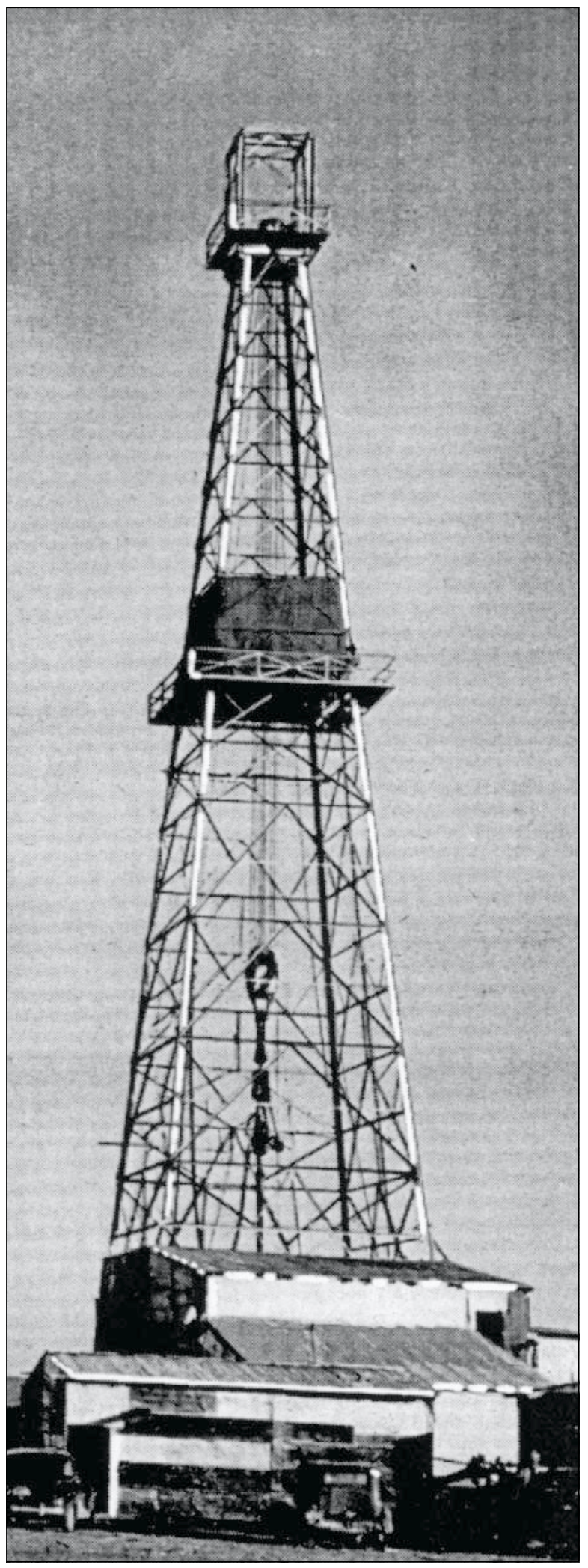
able resources. With each new field came wildcatters and roughnecks who, in time, would move on, and oil companies, who could hope for long-term stays near successful fields. The companies drilled, pumped, and refined oil and natural gas, and sent their products on to bulk terminal plants. Texas operators produced almost 70 million barrels of oil in the first quarter of 1929. Ten companies produced more than half of these barrels: Gulf Production Company, Humble Oil and Refining Company, Southern 
Crude Oil Purchasing Company, Texas Company, Shell Petroleum Corporation, Yount-Lee Oil Company, Magnolia Petroleum Company, J. K. Hughes Oil Company, Pure Oil Company, and Mid-Kansas Oil and Gas Company. Independent operators were prolific until the late 1930s, processing half of the crude oil procured. By 1937, only a handful of significant independents were in operation. The role of independents in earlier years, and their gradual consolidation, is evident in buildings and structures associated with the industry that became increasingly standardized with corporate control.

In the 1940s and 1950s, the industry experienced several shifts. Natural gasoline plants became important as urban markets developed. As a result, casinghead, cycling, and gas-iniection facilities were more prevalent. In the post-World War II-era, demand for oil products soared and was met with imported crude oil, impeding domestic exploration. Nevertheless, pipeline construction for gas transmission exceeded 15,000 miles in Texas, and crude oil trunk lines exceeded 26,000 miles. Even greater standardization was evident in construction associated with the industry during the postwar era, as several manufacturers sold constituent parts of all types of buildings and structures, usually metal, that could be assembled on site. Each manufacturer marketed its own specialization, be it a certain form of roof, seam, or ribbed siding. Still, their products looked remarkably similar without close inspection. Manufacturers of these buildings can often be identified by name, which may appear at the apex of gable ends, along eave lines, or in other near fenestration.

The property types associated with the petroleum and natural gas industry and discussed in this field guide are bulk terminal plants, tanks and tank farms, refineries, natural gas plants, pipelines, derricks and drill rigs, pump houses and pump stations, pump units, power houses and boiler houses, separators and metering stations, supply depots, and warehouses. 


\section{Bulk Terminal Plants}

\section{Character-defining Features}

- Complex of buildings and structures

> Office building

- Warehouse

- Bulk oil storage tanks

- Loading racks

- Signage identifying associated company and manufacturer

- Earthen berms, dikes, and ditches

- Railroad sidings or on main railway line

\section{Principal Subtypes}

\section{Regional Bulk Terminal Plants-}

- Terminal office

- Light products barrel filling area with loading dock

- Several buildings to store canned motor oils, barreled oils, grease and protective coatings, and pallets

- Dispatcher's office

- Battery building

- Service station equipment and supply building

> Tire building

- Barrel cleaning and reconditioning area

\section{Local Bulk Terminal Plants-}

- Office and warehouse in a single building

- Combined bulk oil and light products storage with loading dock

\section{Comments}

Tank trucks, truck trailers, and railroad tank cars transport refined oil products from refineries to bulk terminal plants. In turn, bulk terminal plants, also known as oil depots, supply the products to service stations, homes, farms, and other consumers. Buildings and structures at bulk terminal plants are strictly functional and any stylistic influences reflect emerging industrial design trends that rejected ornamentation. Early-twentieth-century office buildings and warehouses where the public was received are an exception to this general rule, and may feature modest classically inspired detailing such as symmetrical fenestration patterns, emphasized cornice and frieze lines, and prominent central entryways. Those constructed in the 1920s and 1930s may exhibit Art Deco or Art Moderne attributes. Office buildings and warehouses constructed in the mid-twentieth century likely employ International Style design principles. More often, these later office buildings are metal and without detail. As large oil companies adopted standardized designs, buildings were more likely to articulate corporate logos and uniform plans. The constituent parts of a bulk terminal plant could be purchased from several different manufacturers and assembled on site where signage identified both manufacturer and ownership.

To meet the needs of a region, larger bulk terminal plants have considerable space requirements. Similar to regional bulk terminal plants, local versions operate on a smaller scale, usually from a single building. Even the smallest towns in Texas often have more than one bulk terminal plant, each associated with a different oil company. 

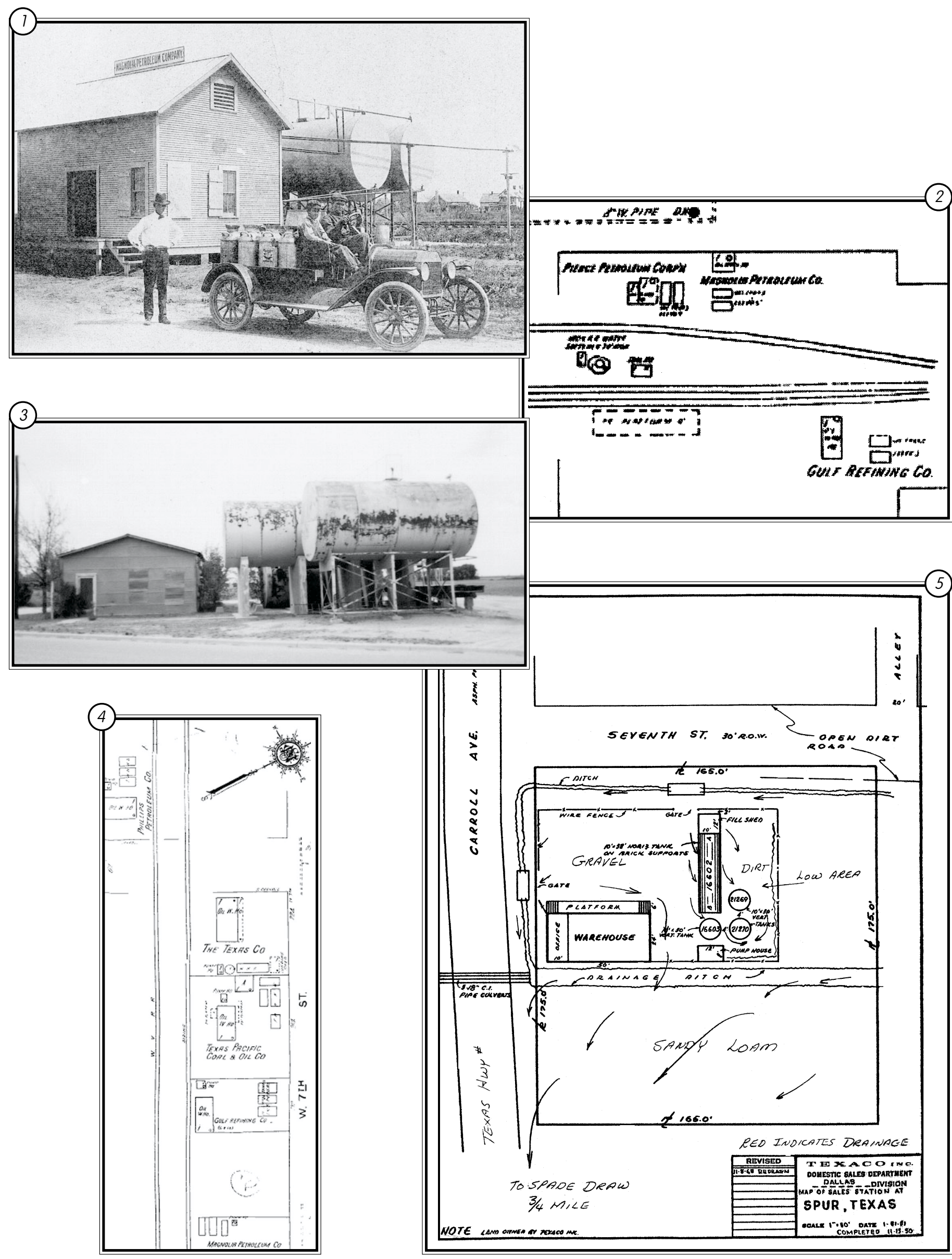


\section{Bulk Terminal Plants}
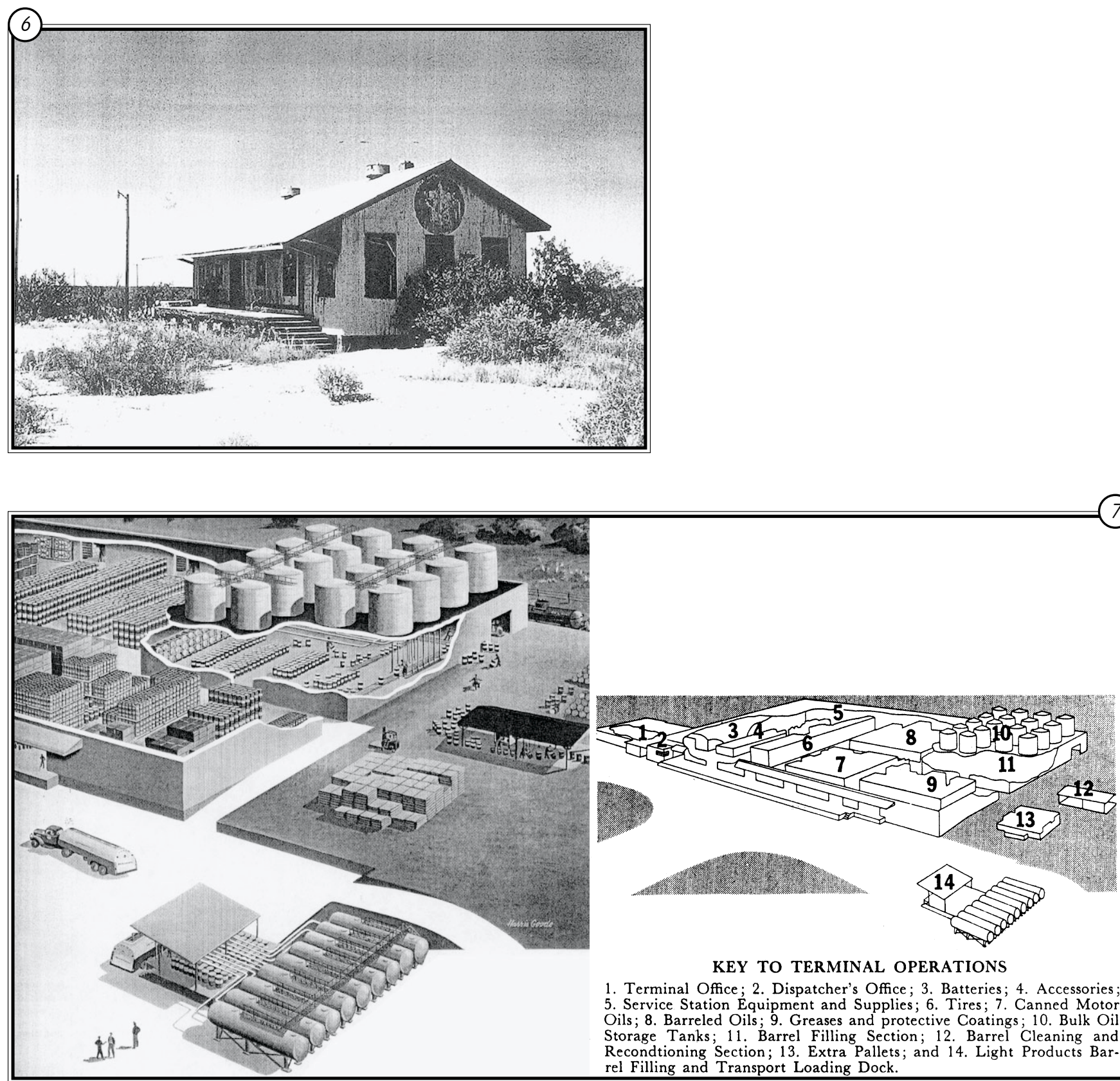

KEY TO TERMINAL OPERATIONS

1. Terminal Office; 2. Dispatcher's Office; 3. Batteries; 4. Accessories; 5. Service Station Equipment and Supplies; 6 . Tires; 7. Canned Motor Oils; 8. Barreled Oils; 9. Greases and protective Coatings; 10. Bulk Oil Storage Tanks; 11. Barrel Filling Section; 12. Barrel Cleaning and Recondtioning Section; 13. Extra Pallets; and 14. Light Products Barrel Filling and Transport Loading Dock.

1 The Magnolia Petroleum Company had opened a local bulk terminal plant in Merkel by 1925. Signage for the company is perched atop the wood building, which served the combined functions of office and warehouse.

2 Sharing the railroad siding with the Magnolia Petroleum Company in Merkel were both the Gulf Refining Company and the Pierce Petroleum Corporation. Each of these local bulk terminal plants had a single building, tank storage, and loading docks.

3 The ca. 1930 Magnolia Petroleum Company's local bulk terminal plant, along the railroad siding in O'Donnell, had competition from both the Continental Oil Company and the Gulf Refining Company by 1935. The oil and light products storage tanks dwarf the metal office and warehouse building.

4 By 1929, at least five oil companies, including the Texas Company, operated local bulk terminal plants along the railroad in Spur.

5 The three tanks on this site of the Texas Company, which became Texaco, in Spur could hold almost 35,000 gallons of refined oil products. The site footprint shows precautions taken, especially in the late twentieth century, to contain spills and fires.

6 A more-recent photograph shows the abandoned Texaco bulk terminal plant in Spur with its loading dock and fading Texaco sign.

$7 \quad$ This 1951 diagram of a regional bulk terminal plant shows the many attributes a large facility required. 


\section{Tanks and Tank Farms}

\section{Character-defining Features}

- Wood or steel construction usually on concrete slab

- Cylindrical or spherical

- Ladders or stairways along the exterior of each tank

- Catwalks or runways between tanks

- Signage identifying associated company and manufacturer

- Earthen berms, dikes, and ditches often surround tanks

\section{Principal Subtypes}

\section{Wood Crude Oil Tanks-}

- Wood-stave construction with narrow strips of wood forming cylindrical side walls

- Flat wood covers

- Ladders and catwalks

\section{Metal Crude Oil Tanks-}

- Large pieces of steel bolted or welded together forming cylindrical side walls

- Flat metal covers on bolted models

- Conical metal covers on welded models

- Stairways and runways

\section{Spheroidal Tanks-}

- Large pieces of steel welded together forming spherical side walls

- Stairways and runways

\section{Tank Farms-}

- Complex of several to many large tanks storing crude oil

- Berms and ditches surrounding tanks

- Railroad sidings or on main line

- Coastal tank farms have dock facilities

\section{Comments}

Tanks provide storage for a variety of petroleum and natural gas products. They can serve as field storage, field processing, or semipermanent storage at wells, tank farms, refineries, or bulk terminal plants. In the oil fields, storage and processing tanks near wells might require only a few tanks for a smaller field, or a tank farm for a larger field. Large tank farms store crude oil before it is shipped to refineries. Tank farms are often near refineries and must be proximate to main railroad lines or waterways for shipping.

The largest tanks store crude oil, while smaller tanks hold other petroleum products, such as gasoline, kerosene, motor oil, or ethyl. Tanks constructed from the 1920s through the 1950s could usually store from 500 to 80,000 barrels or more of crude oil. Welded tanks can better handle higher air pressure than bolted models and can function horizontally or vertically. For certain oil products and natural gas, which require storage under very high pressure, spheroidal tanks were developed. Ladders, stairways, catwalks, and runways allow operators to maintain tanks and monitor their contents. Berms and ditches provide drainage in the case of a spill or leak.

Tanks are strictly functional and any stylistic influences reflect emerging industrial design trends that rejected ornamentation. These structures could be purchased from several different manufacturers and assembled on site where signage identified both manufacturer and ownership.

The number of tank farms and their size expanded rapidly in the twentieth century for several reasons. The demand for gasoline to power automobiles rose dramatically in the 1920s, when automobiles first proliferated, and again after World War II, when the postwar economic boom allowed even more people to own vehicles. The 


\section{TANKS AND TANK FARMS}

economic boom led to a rise in production of consumer goods that were as likely to be distributed by truck as by rail. The growth of tank farms also paralleled corporate consolidation of independent oil companies as operations became centralized. Technological improvements in the postwar era led to tank construction that allowed for larger holding capacities. By the mid-twentieth century, improvements to pipeline technology furthered movement of crude and processed oil more efficiently, which drew on the stored reserves of tank farms.
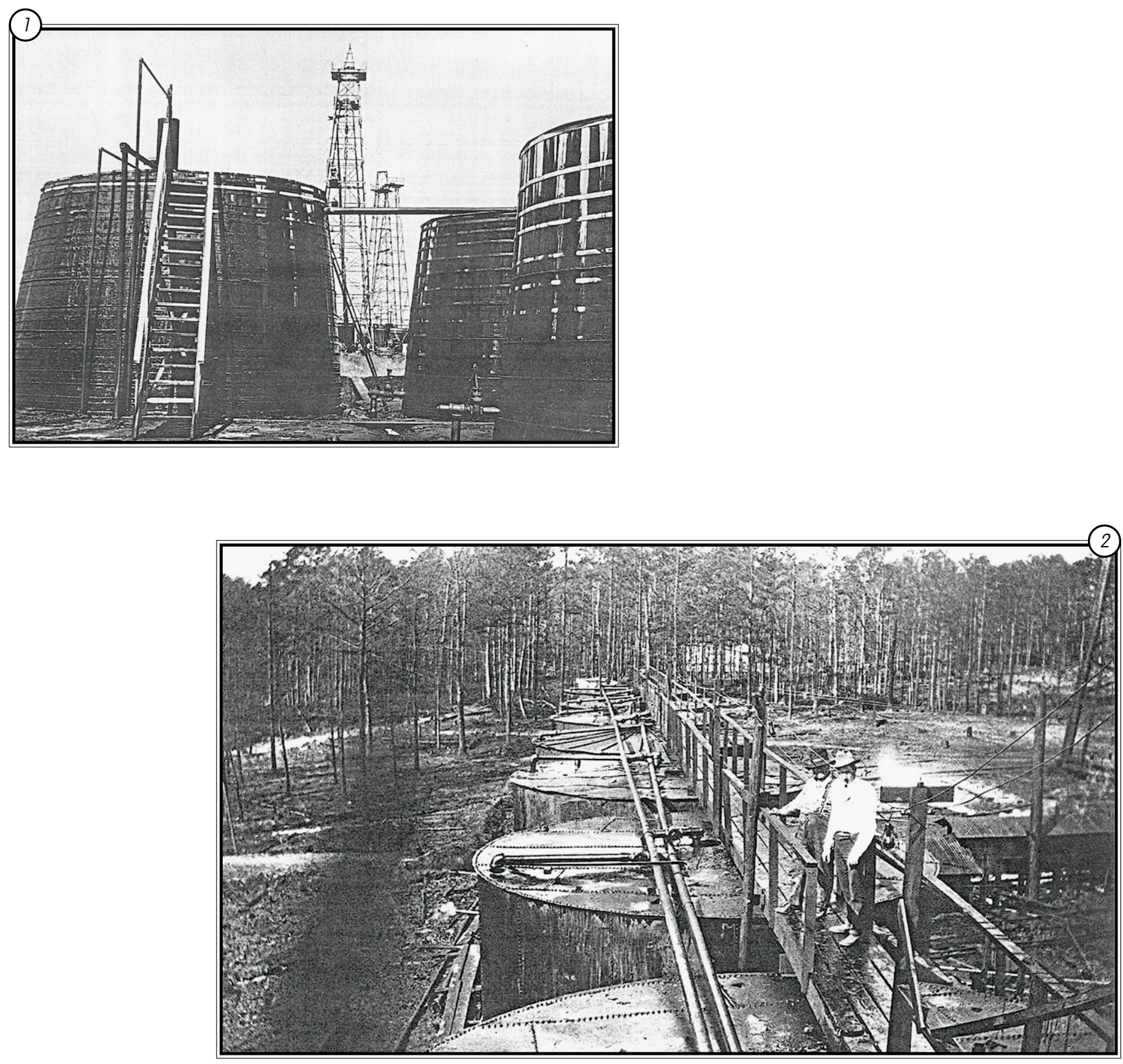

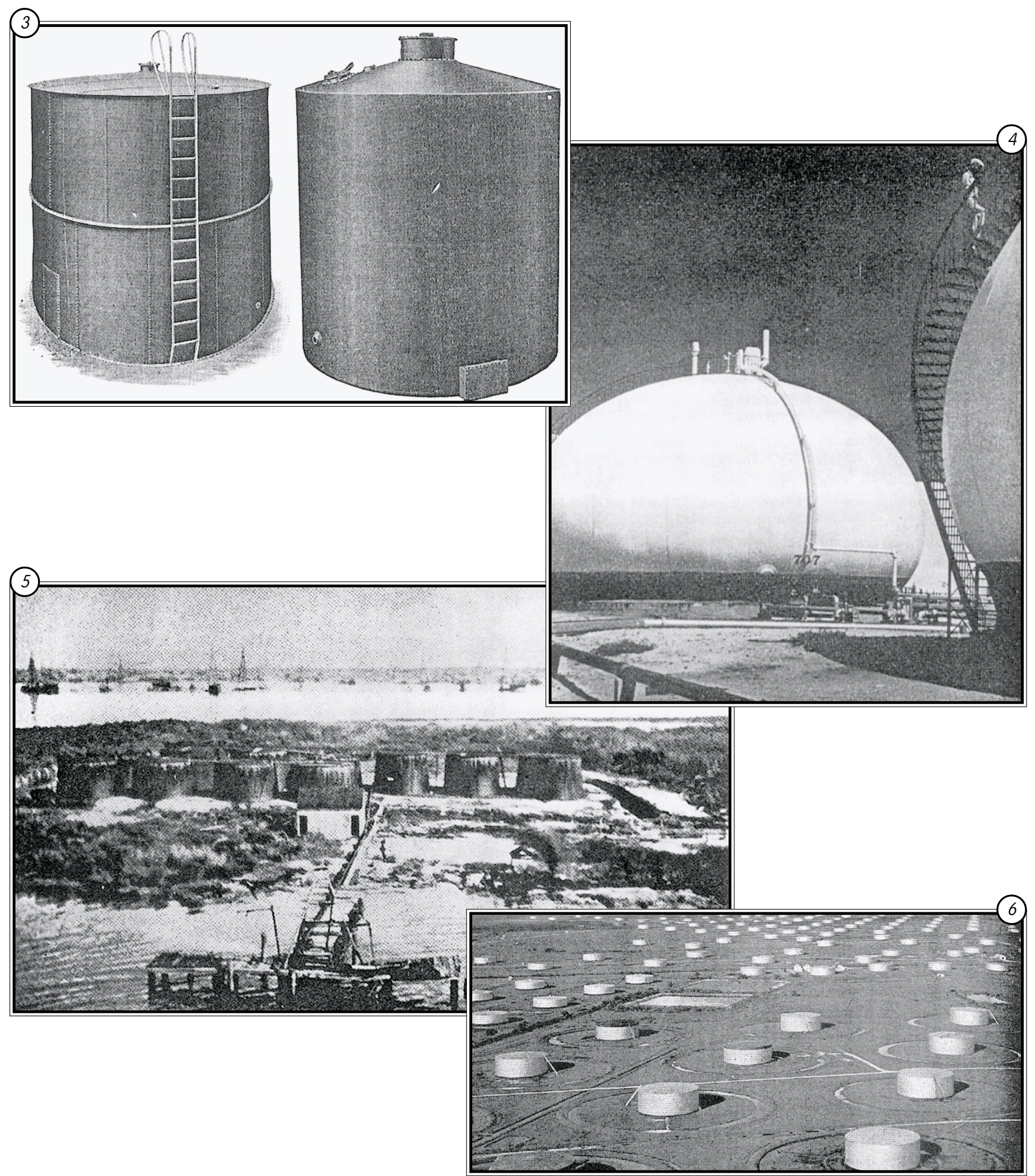

3 In 1929 the Butler Manufacturing Company marketed and sold metal crude oil tanks with both flat and conical covers.

$4 \quad$ This ca. 1960 spheroidal tank was used for high-pressure oil products and natural gas.

5 This ca. 1919 image shows the Humble Oil \& Refining Company's first dock, pump station, and tank farm in the Goose Creek field.

6 Stanolind Oil Purchasing Company operated this tank farm, which was one of the largest in the world in 1951. The tanks hold either 55,000 or 85,000 barrels of crude oil, with a total of 5 million barrels on site. 


\section{REFINERIES}

\section{Character-defining Features}

- Complex of buildings and structures

- Crude oil storage tanks

- Pipe stills

- Bubble tower

- Condenser

- Boiler house

- Equipment to process crude oil

- Storage tanks holding processed materials

> Pipelines

- Office building

- Warehouses

- Signage identifying associated company and manufacturer

- Earthen berms, dikes, and ditches often surround tanks

- Railroad sidings or on main railway line

\section{Principal Subtypes}

\section{Major Refineries-}

- Large facilities may include equipment to process crude oil into motor fuel, kerosene, and heavy fuel oils

\section{Independent Refineries-}

> Smaller facilities

- Must include equipment to process crude oil into motor fuel, kerosene, and heavy fuel oils

\section{Comments}

Refineries receive crude oil by railroad or pipeline, store the oil, then process it into refined products. Refining crude oil requires moving it through a pipeline from storage tanks to pipe stills. The still heats the crude oil and vapors pass to a bubble tower where they are separated into various raw products (i.e., gasoline, kerosene, gas oil, lube distillate, and heavy bottoms). These raw products are condensed back into liquids and undergo additional processing. Raw gasoline is purified into motor fuel; raw kerosene is agitated into finished kerosene; gas oil is sent through a cracking unit that heats, reacts, evaporates, and cools to make heavy fuel oils, or can be bubbled and condensed to make cracked gasoline that can be processed into motor fuel; lube distillate is agitated, treated, chilled, and filtered to make wax, or de-waxed and percolated to make finished lubricating oils; heavy bottoms are distilled to make coke and further distilled to make asphalt, or distilled and then condensed to make raw gasoline, gas oil, or paraffin oil.

Small, independent refineries were abundant until the 1930s, when the Great Depression or major refineries put them out of business. Only a few significant independent refineries remained in the state at mid century. Often a major refinery would purchase failed independents and either close the facility or expand its operations under new ownership. Major refineries had entered Texas just after the turn of the century. By the late 1930s, the majors processed about half of all crude oil produced in the state; by mid century they had even greater control of production and refining. Most of the buildings and structures that are part of a refinery are strictly functional and any stylistic influences reflect emerging industrial design trends that rejected ornamentation. Office buildings are an exception to this general rule, and early examples may feature modest classically inspired detailing such as symmetrical fenestration patterns, emphasized cornice and frieze lines, and prominent central entryways. Office buildings constructed in the 1920s and 1930s may exhibit Art Deco or Art Moderne attributes. Those 


\section{REFINERIES}

constructed in the mid-twentieth century likely employ International Style design principles. More often, these later office buildings are metal and without detail. As large companies adopted standardized designs, buildings were more likely to articulate corporate logos and uniform plans. The constituent parts of a refinery could be purchased from several different manufacturers and assembled on site where signage identified both manufacturer and ownership.

Major refineries handle all aspects of crude oil production, while independent refineries typically, are "topping" plants that process lighter products that can be easily distributed locally or regionally, such as motor fuel, kerosene, and heavy fuel oils. Independents have the constituent parts, such as storage tanks, pipe stills, bubble towers, and condensers, to process crude oil. However, they typically send raw lube distillate and heavy bottoms, which make up only a small percentage of each barrel refined and are not as readily marketed, to major refineries for processing. Independents handle fewer barrels of crude oil than a major refinery and require less storage space.
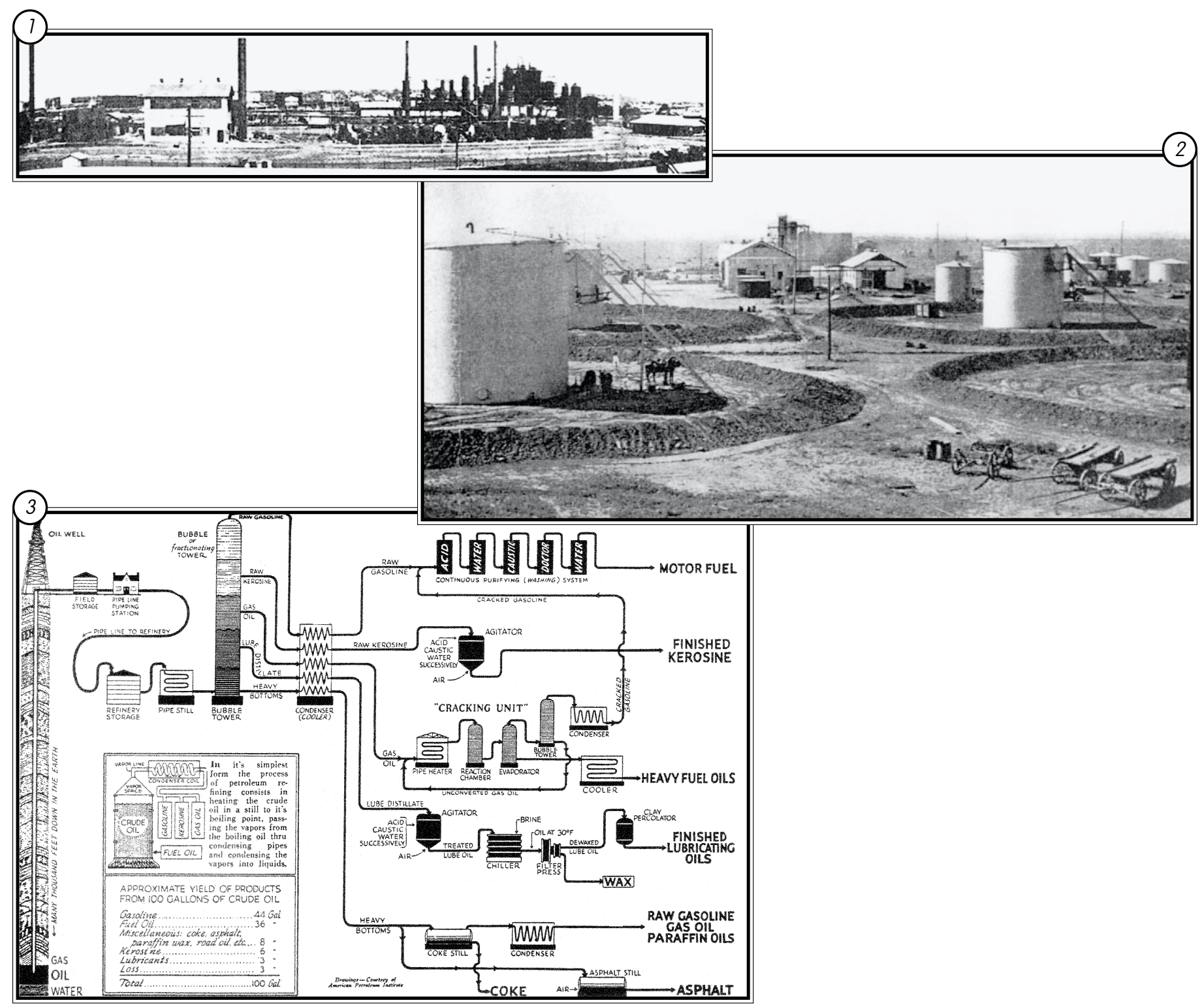

1 The Continental Oil Company had this major refinery in Wichita Falls in the mid-1920s.

2 Humble Oil Company built several major refineries in the 1920s. They constructed this one in Burkburnett in about 1925.

$3 \quad$ Published in 1934, this flow chart traces crude oil from well to finished product. 


\section{REFINERIES}
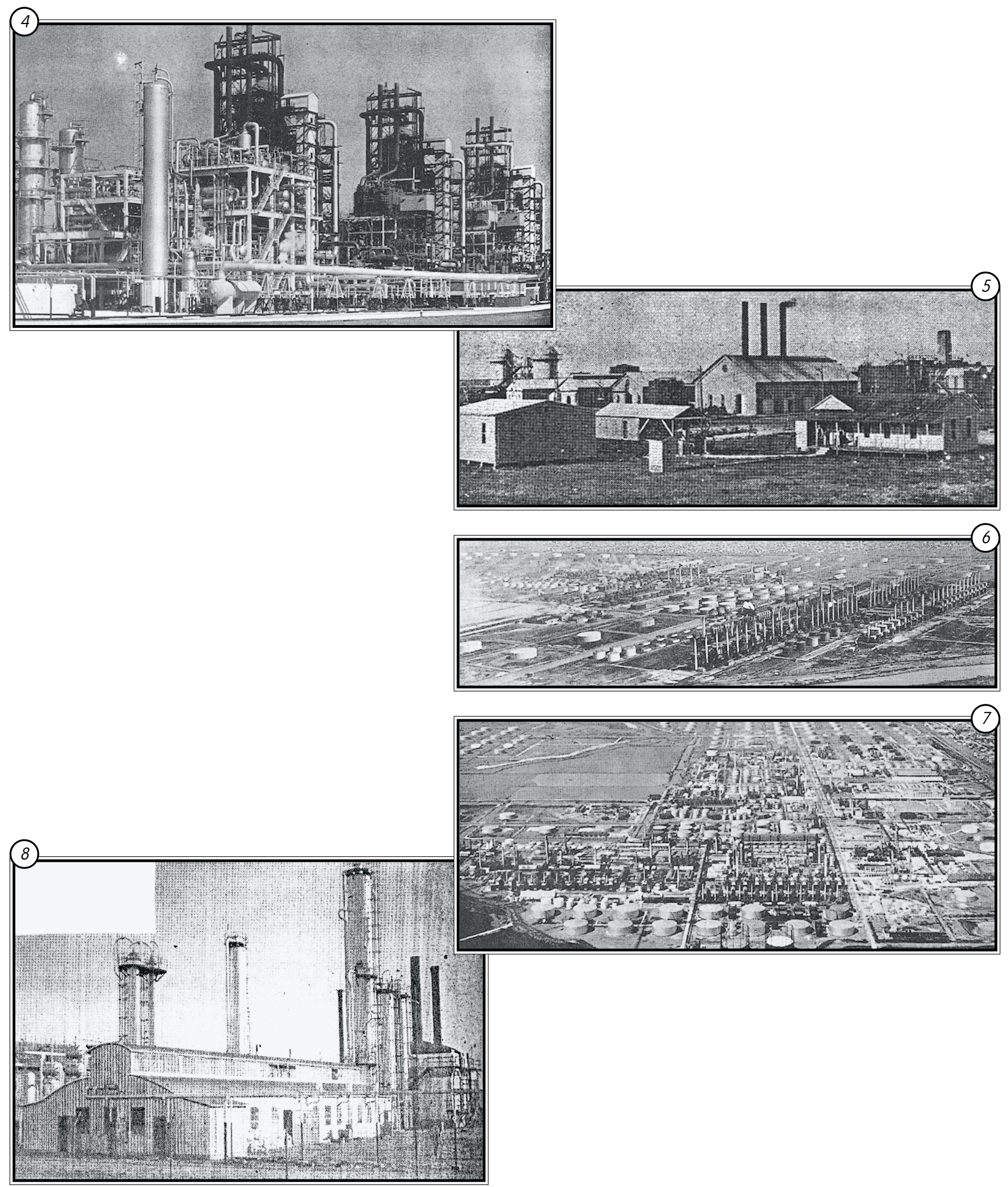

$4 \quad$ This giant catalytic cracker processed gas oil into heavy fuel oils in the early $1950 \mathrm{~s}$.

5, 6, 7 The Texas Company's major refinery at Port Arthur in 1902 (5), 1926 (6), and 1950 (7), expanded from a topping plant handling a few hundred barrels a day into a complete refinery.

8 The Butler Manufacturing Company marketed and sold this warehouse to oil companies in the mid-1940s. 


\section{Natural Gas Plants}

\section{Character-defining Features}

> Complex of buildings and structures, usually in an oil field

- Office building

- Warehouse protecting compressors and equipment

- Cooling towers

- Absorbing units

- Tanks storing unprocessed natural gas and refined products

- Signage identifying associated company and manufacturer

- Earthen berms, dikes, and ditches

- Railroad sidings or on main railway line

\section{Principal Subtypes}

\section{Casinghead Gas Plants-}

- Equipment to process natural gas from crude oil wells

- Equipment to remove propane and reduce butane from natural gas

\section{Gas-cycling Plants-}

- Equipment to process natural gas from crude oil wells

- Equipment to remove propane and reduce butane from natural gas

- Equipment to process light condensates

> Gas-injection facility on site

\section{Gas-injection Facilities-}

- Part of gas-cycling plant or independent facility

- Equipment to recover crude oil and its byproducts and pipe them back into the ground

\section{Comments}

Also known as raw, bradenhead, or natural gasoline, casinghead gasoline is a byproduct of natural gas. The components of natural gas plants are strictly functional and any stylistic influences reflect emerging industrial design trends that rejected ornamentation. Office buildings are an exception to this general rule, and early examples may feature modest classically inspired detailing such as symmetrical fenestration patterns, emphasized cornice and frieze lines, and prominent central entryways. Office buildings constructed in the 1920s and 1930s may exhibit Art Deco or Art Moderne attributes. Those constructed in the mid-twentieth century likely employ International Style design principles. More often, these later office buildings are metal and without detail. As large companies adopted standardized designs, buildings were more likely to articulate corporate logos and uniform plans. The constituent parts of a natural gas plant could be purchased from several different manufacturers and assembled on site where signage identified both manufacturer and ownership.

Casinghead gas plants apply pressure to and cool natural gas from crude oil wells, thus making a product similar to refined gasoline. Casinghead plants can also remove propane and reduce butane elements from natural gasoline to meet grade specifications. The company could then also market the propane and butane.

Like casinghead plants, gas-cycling plants process natural gas. Sometimes these plants are aptly referred to as recycling plants. In addition to natural gasoline, butane, and propane, gas-cycling plants also process light condensates, such as motor fuel, kerosene, gas oil, and oil bottoms. A medium-sized plant in 1938 could process 50 million cubic feet of natural gas daily. Gas-cycling plants are likely to include a gas-injection facility.

Gas-injection facilities allow for secondary recovery of crude oil and its byproducts by processing natural gas gathered at a well and piping it back into the ground to maintain reservoir pressure. These facilities are typically part of a gas-cycling plant but can exist independently. 


\section{Natural Gas Plants}
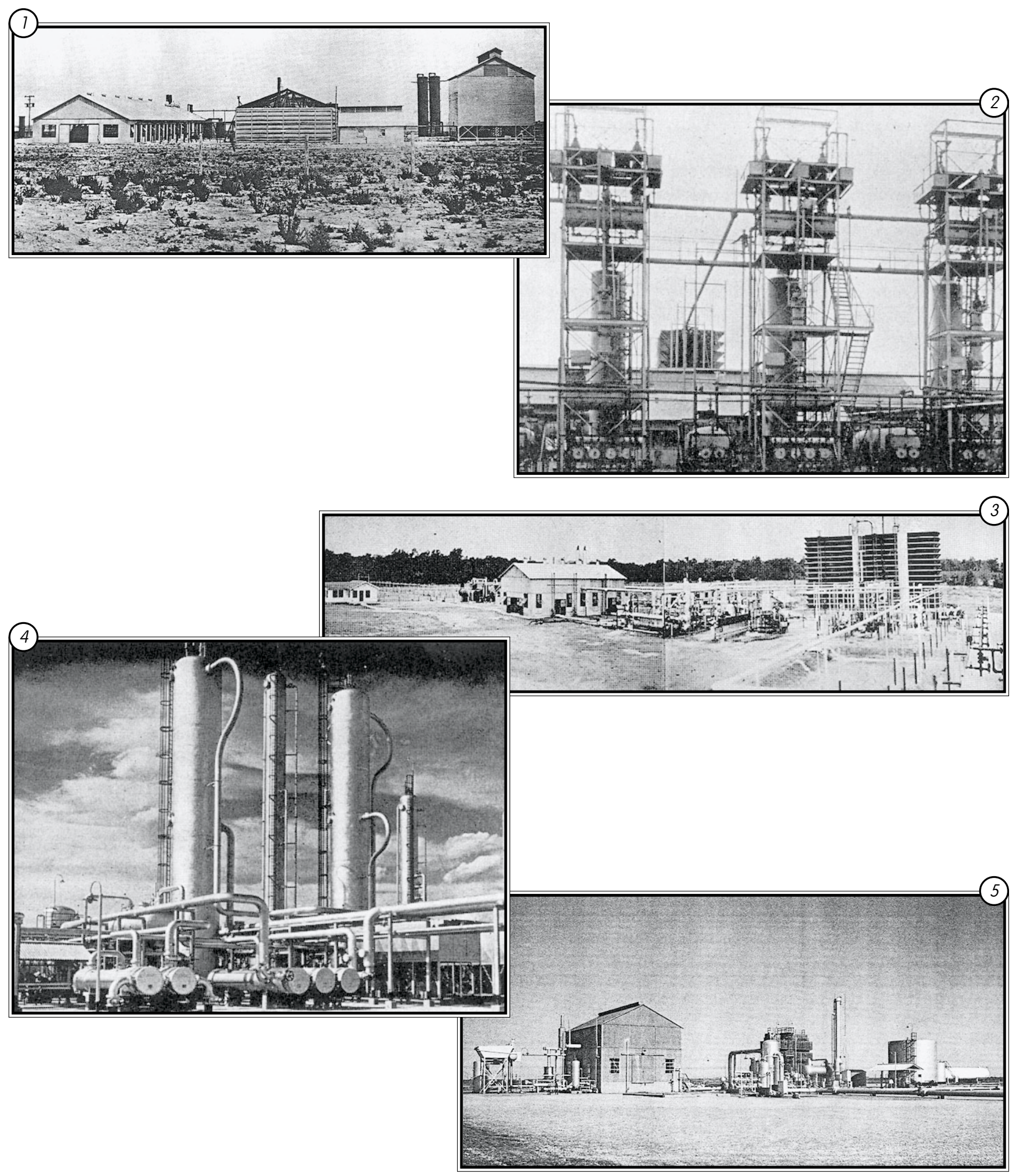

1 In 1925, 70 percent of the casinghead gas at the Big Lake Oil Company's plant in Texon needed no refining.

2 These towers recovered propane and butane from natural gas at a casinghead gas plant in Oklahoma in 1926.

3 Operations at this natural gas-cycling plant at Cayuga field in Anderson County began in 1938.

$4 \quad$ Stanolind Oil \& Gas Company operated this casinghead gas plant in North Cowden after World War II.

$5 \quad$ This gas-injection facility on the Anton-Irish field in Hale County dates to the early 1950s. 


\section{Pipelines}

\section{Character-defining Features}

- Usually underground, but can be above ground

- Pipe sections range from 35 to $50 \mathrm{ft}$ in length

- Wrought-iron, mild-steel, or open-hearth steel

- Units are lap-welded together at pipe yard or in field

- Signage identifying associated company for above-ground pipeline features

\section{Principal Subtypes}

\section{Pipeline Fountain Heads-}

> Steel

- Small diameter

- Lightweight

- Increase in size, weight, and length as joined with larger gathering lines

\section{Gathering Lines-}

$>$ Steel

- Medium diameter, usually between 2 and 4 inches

- Medium weight

\section{Trunk Lines-}

> Steel

- Large diameter, usually between 4 and 16 inches

> Heavy weight

- May include main, way, and branch lines

- May include yards, stations, depots, and pump stations

\section{Natural Gas Lines-}

> Wrought or cast iron

- Local lines from 2.0 to 2.5 inches in diameter

- Main lines from 16 to 24 inches in diameter

\section{Comments}

Pipelines are critical to moving crude oil, refined oil products, and natural gas. By 1941, pipelines transported 75 percent of crude oil to refineries in the United States. Texas had 28,600 miles of natural gas lines by 1938, and more than 12,600 miles of gathering and 20,400 miles of trunk lines by 1939 .

Pipeline fountain head connect wells or field storage tanks to gathering lines. Also known as feeders, gathering lines transport crude oil from pipeline fountain heads to refineries. Trunk lines are long pipes that carry crude oil from the mouth connections of gathering lines for long-distance shipment to major refineries or points of wide distribution. Some trunk lines cross several state lines and can be hundreds of miles long. Natural gas lines function in the same way as those constructed for oil. Pipelines are strictly functional and bear no stylistic influences. They could be purchased from several different manufacturers and assembled on site where signage identified both manufacturer and ownership. 


\section{PIPELINES}

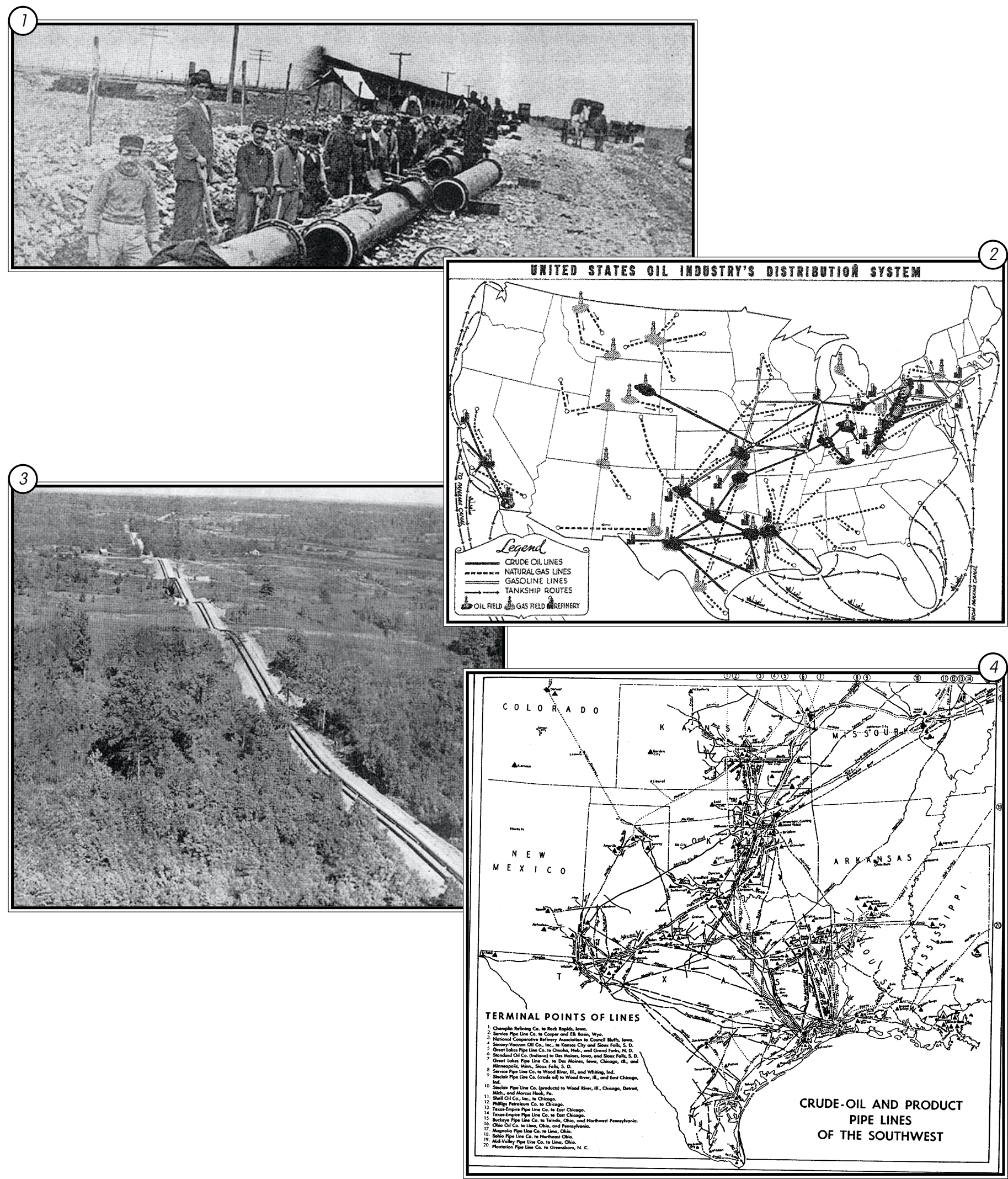

1 A natural gas pipeline was laid from the Petrolia field in North Texas to Fort Worth in 1909.

2 This 1941 map indicates the significance of trunk lines that radiate from Texas to the country's oil distribution system.

3 At the end of World War II, natural gas pipeline construction became unprecedented and an increasingly familiar industrial property on the landscape.

$4 \quad$ This 1951 map gives a general impression of the many crude and refined oil pipelines in Texas and surrounding states. 


\section{Derricks ANd Drill Rigs}

\section{Character-defining Features}

- Wood or steel framework

- Wood, steel, or concrete substructure

- Steel and metal machinery, such as hoists, pumps, boilers, and brakes

- Steam-, electric-, or gas-powered engine

- Signage identifying associated company and manufacturer

\section{Principal Subtypes}

\section{Derricks-}

- Usually very tall wood or steel framework

- Wood, steel, or concrete substructure housing drill rig and machinery

\section{Drill Rigs-}

- Wood, steel, or concrete substructure housing drill rig and machinery

- Cable-tool or rotary drill rig positioned underneath derrick

- Steam-, electric-, or gas-powered engine

\section{Comments}

Derricks support boring equipment over a drilled hole. Wood derricks were common only in the early years of oil production. They were, however, unstable and fire-prone. By the 1910s, the use of structural steel had become widespread for derrick construction, as well as for the substructure. Early drill rigs were positioned under wood or metal derricks. Cable-tool drilling was overtaken by more efficient rotary rigs by the late 1920s, except in shallow hard-rock areas, where cable-tool drilling continued to be most effective. Rigs could be powered by steam, electricity, or gas-powered engines. Derricks and drill rigs are strictly functional and any stylistic influences reflect emerging industrial design trends that reject formal ornamental schemes. They could be purchased from several different manufacturers and assembled on site where manufacturer and ownership might be identified with corporate signage. By the mid-twentieth century, mobile truck-mounted, motorized drill rigs made derricks obsolete.

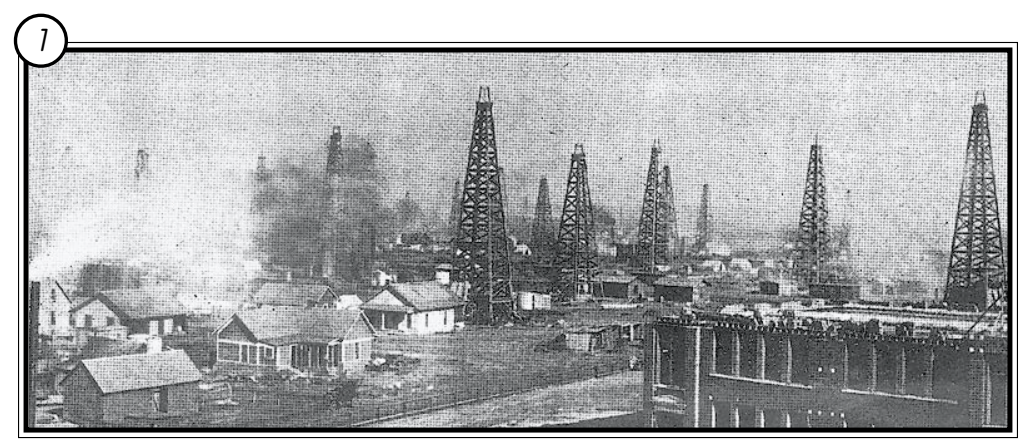

$1 \quad$ Wood derricks lined Burkburnett in 1919.

2 This steam-powered cable-tool rig is under a wood derrick.

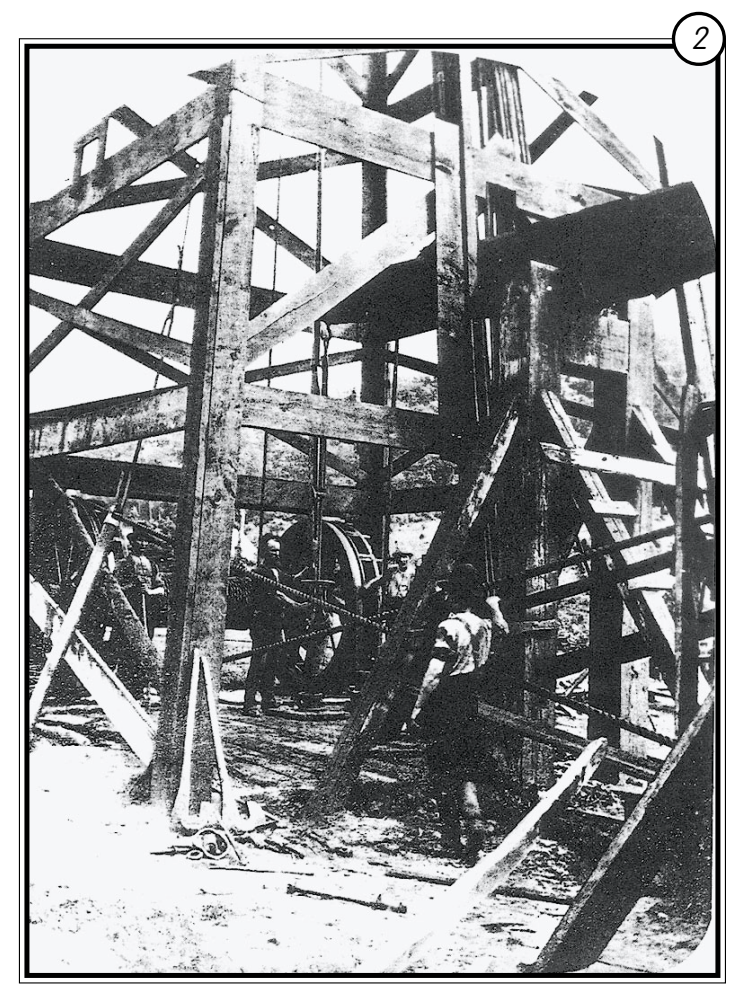




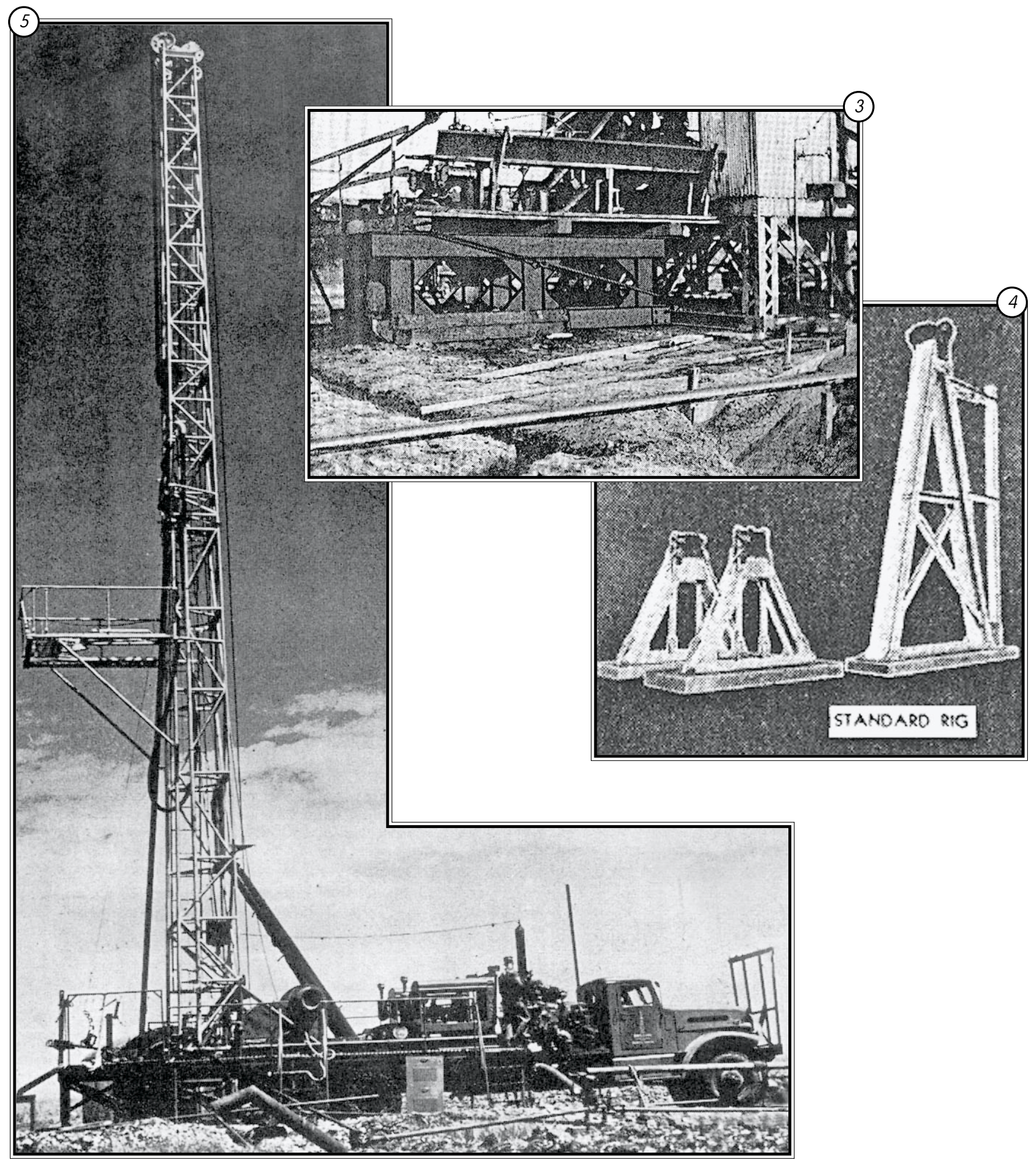
This standard drill rig was manufactured and marketed by International Derrick \& Equipment Company in 1934.

5 Truck-mounted motorized drill rigs, like this one manufactured by Joy Manufacturing Company in 1951, became the preferred method of drilling since the entire unit was all-inclusive and mobile. 


\section{Pump Houses and Pump Stations}

\section{Character-defining Features}

- Gable roof

- Concrete foundation

- Steel construction and metal siding

- Rectangular plan

- One entryway on main façade

- Windows, when present, typically are steel casement with six panes

- Signage identifying associated company and manufacturer

\section{Principal Subtypes}

\section{Pump Houses-}

- Small buildings with just enough floor space to house pumping equipment

- Usually in oil fields

- Part of a complex that might include derricks and tanks

\section{Pump Stations-}

- Commodious building housing large pumping equipment

- Usually about every 40 miles along pipelines

- May be part of a complex that includes pipelines, tanks, or both

\section{Comments}

Pump houses and pump stations provide shelter for equipment critical to moving crude oil, refined oil products, or natural gas from their source to storage, or from storage to refineries. Within these buildings, diesel, steam, electric motor, or gas engine pumps force the product through pipelines. Smaller pump houses are usually in oil fields and the equipment they house moves petroleum from wells to nearby flow tanks and field storage tanks if the force of gravity alone cannot. Substantially more commodious than pump houses, pump stations have more and larger equipment along pipelines that link field storage tanks and tank farms, or those that link directly to refineries. Pump stations are also known as pipeline terminals. These buildings may be in the oil field, at tank farms, or along pipelines. They are spaced about every 40 miles along most pipelines, but are closer together in hilly terrain. These buildings are strictly functional and any stylistic influences reflect emerging industrial design trends that rejected ornamentation. These buildings could be purchased from several different manufacturers and assembled on site where signage identified both manufacturer and ownership.

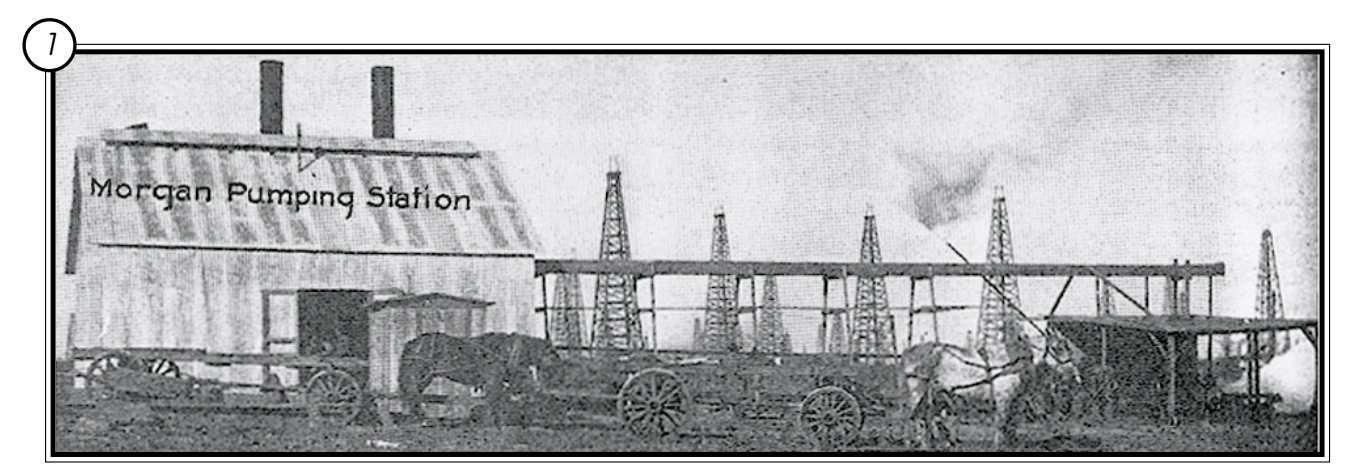



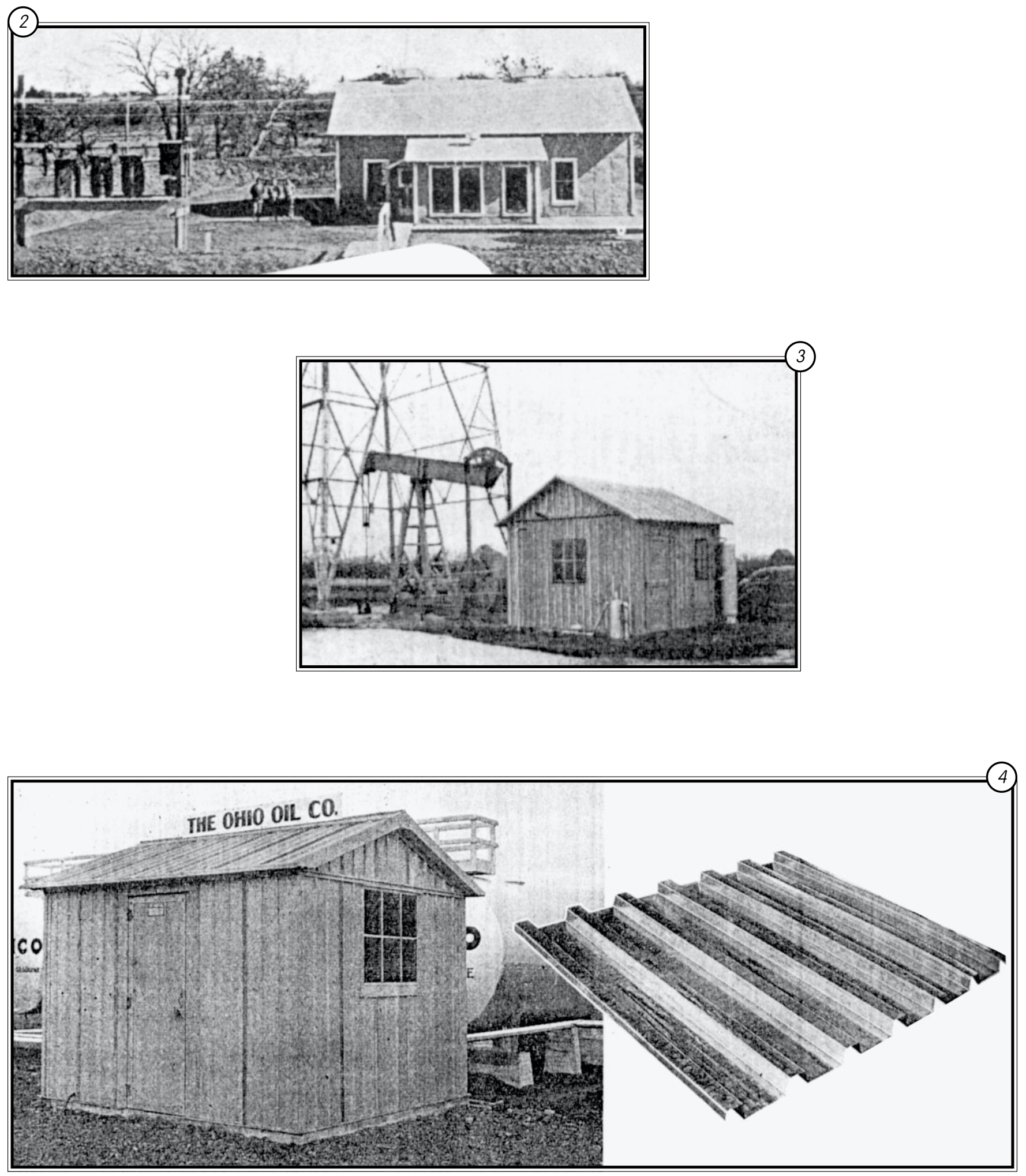

The ca. 1927 Humble Pipeline Station in Pioneer was part of a complex of pipelines and tanks.

3 At the foot of a derrick with drill rig, this typical metal pump house was made of structural steel and sheathed with galvanized steel in 1946. The materials and plan were those of the Butler Manufacturing Company.

$4 \quad$ The International Derrick \& Equipment Company manufactured this pump house that the Ohio Oil Company was using in 1946. A sample of IDECO siding shows the manufacturer's preferred rib pattern. 


\section{Pump UnITs}

\section{Character-defining Features}

- Metal construction

- Base plate, braces, pitman pipe, casing head, flow line, counter-balanced crank, and walking beam

- Signage identifying associated company or manufacturer

\section{Principal Subtypes}

- Numerous subtypes and styles of pump units exist

- Older units link to power houses

- Later units use electric or gasoline engines for power

- Commonly geared or chain rigged

> Single or double crank

\section{Comments}

Many subtypes of pump units exist, but all have the same function. Pump units force oil from a well into flow tanks in the field. Older pump units were run by power houses, later units were commonly geared or chain rigged and run by electric or gasoline motors. They do not run continuously, but as needed, depending largely on crude oil prices. When prices are low, an operator pumps only enough oil to maintain the lease. Stopping a pump allows oil and saltwater to percolate, fill the well, and be ready for pumping again. These structures are strictly functional and bear no stylistic influences. They could be purchased from several different manufacturers and assembled on site where signage identified manufacturer and ownership. 

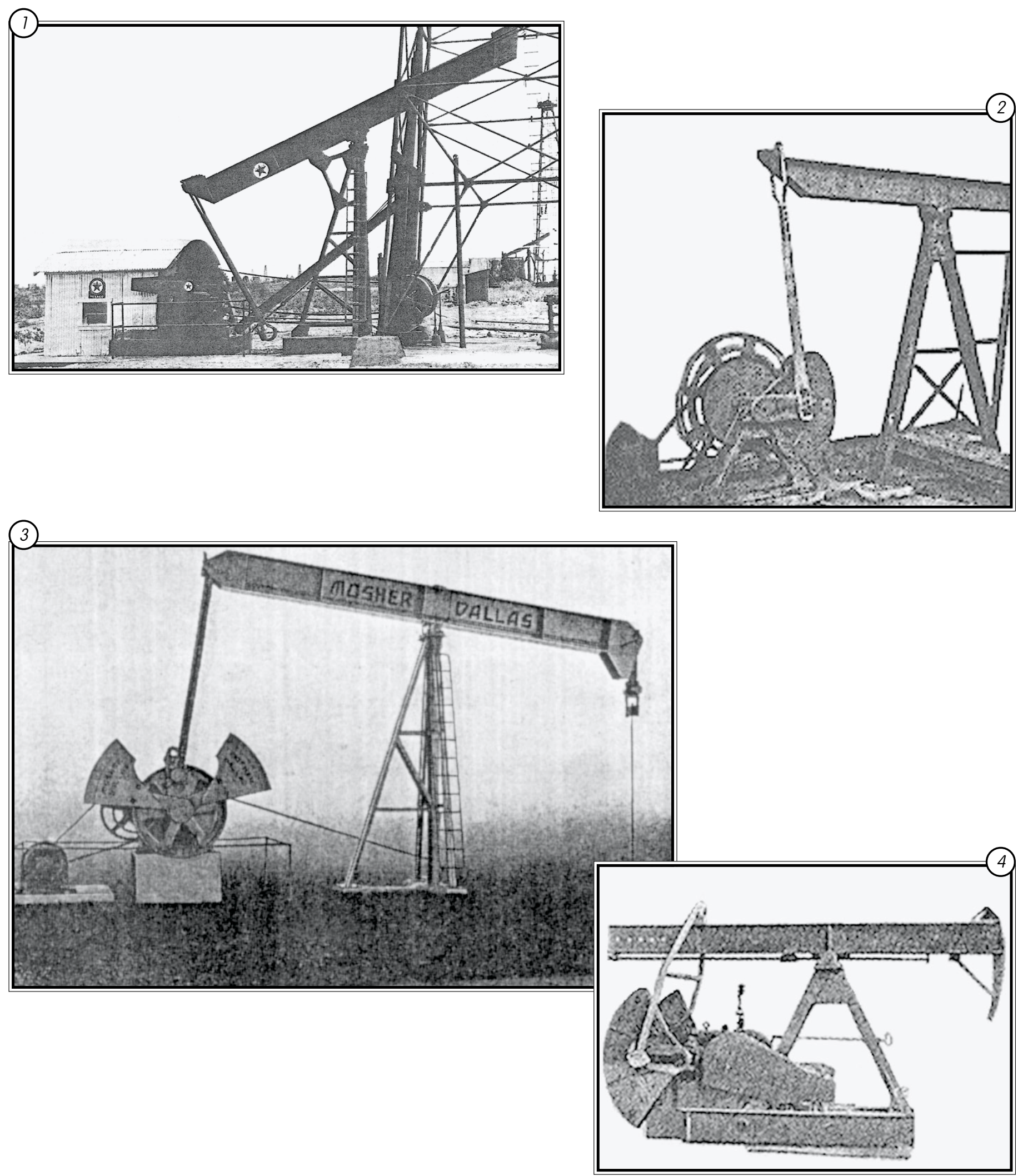

1 Texaco operated this pump unit at Cowden-Anderson No. 14, which yielded 375 barrels a day in 1929. The company's logo is evident on the pump unit and the pump house at left.

2 This chain-rig pumping unit was made in 1930 by the International Derrick \& Equipment Company.

3 A geared pumping unit in 1934 made by Mosher Steel \& Machinery Company sports the company's logo.

4 International Derrick \& Equipment Company sold this twin-crank pumping unit in 1934. 


\section{Power Houses And Boiler Houses}

\section{Character-defining Features}

- Gable roof with one or more vents along the ridgeline

- Concrete foundation

- Steel construction and metal siding

- Rectangular plan

- One entryway on main façade

- Windows, when present, typically are steel casement with six or more panes

- Signage identifying associated company and manufacturer

\section{Principal Subtypes}

\section{Power Houses-}

- Small building with just enough floor space to house boiler equipment

- Usually in oil fields

- Part of a complex that might include derricks and tanks

\section{Boiler Houses-}

- Commodious building housing extensive boiler equipment or engines

- Part of a large complex such as a refinery or tank farm

\section{Comments}

Power and boiler houses, sometimes referred to as engine houses, provide shelter for equipment critical to moving petroleum from oil fields to refineries or to storage. These buildings are strictly functional and any stylistic influences reflect emerging industrial design trends that rejected ornamentation. Power houses were typically small buildings in oil fields, while boiler or engine houses were much larger buildings used at oil refineries or tank farms. They could be purchased from several different manufacturers and assembled on site where signage identified both manufacturer and ownership. 

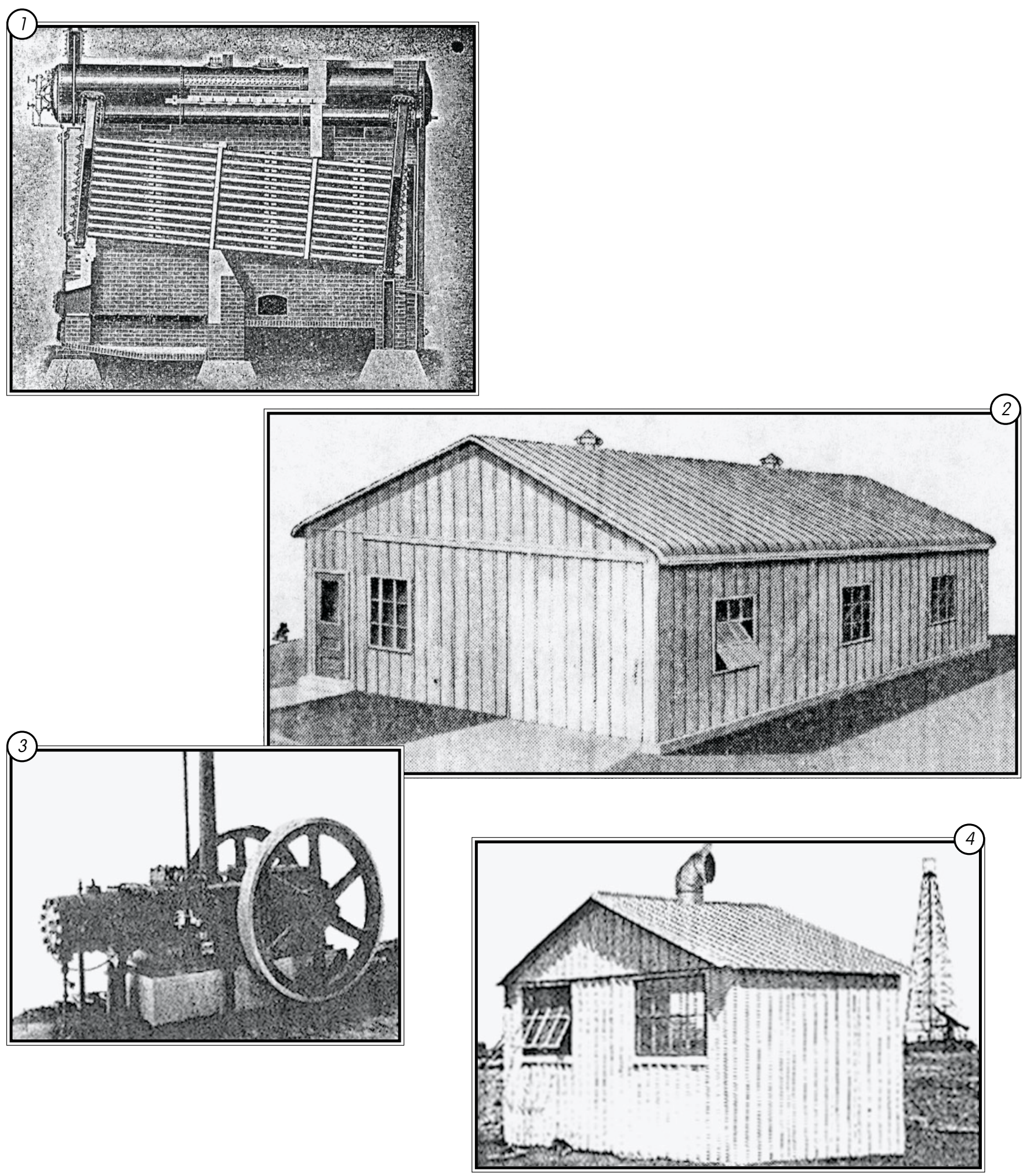

1 Equipment such as this 1920 cross-drum water-tube boiler would be protected within a boiler house.

2 The Columbian Steel Tank Company of Kansas City marketed and sold this large boiler house in 1934 for use at complexes such as oil refineries or tank farms.

3 Numerous types of engines service oil fields, tank farms, and refineries, all of which require protection from the elements. This gas engine was available from the International Derrick \& Equipment Company in 1934.

4 Many small engine houses, such as this one that the Butler Manufacturing Company produced in 1934, were present in oil fields. 


\section{Separators and Metering Stations}

\section{Character-defining Features}

- One or more pumping units

> Tank battery

- Pipeline

- Earthen berms, dikes, and ditches often surround separators and metering stations

> Signage identifying associated company and manufacturer

\section{Principal Subtypes}

\section{Separators-}

- Tank battery with metal gun-barrel tanks, metal saltwater tank, and minimum of two metal crude oil tanks situated lower than the pumping unit

- Heater-treater is sometimes present

- Usually in oil fields

\section{Metering Stations-}

- Metered dispatch tanks

- Usually along pipelines

\section{Comments}

Separators are used in small or declining oil fields where natural pressure is substandard or has decreased. Separators are pressure vessels that use gravity or heat to maintain pressure. The gun-barrel tank separates oil and natural gas from saltwater and distributes each to its own tank. The saltwater must be disposed of away from the active field.

Metering stations dispatch and monitor flow of liquids or gases. Meters are helpful in determining the location of a line failure. Meters can monitor crude oil, refined oil products, or natural gas.

Separators and metering stations can function independently of each other or may be used in consort. These structures are strictly functional and bear no stylistic influences. These structures could be purchased from several different manufacturers and assembled on site where signage identified both manufacturer and ownership. 

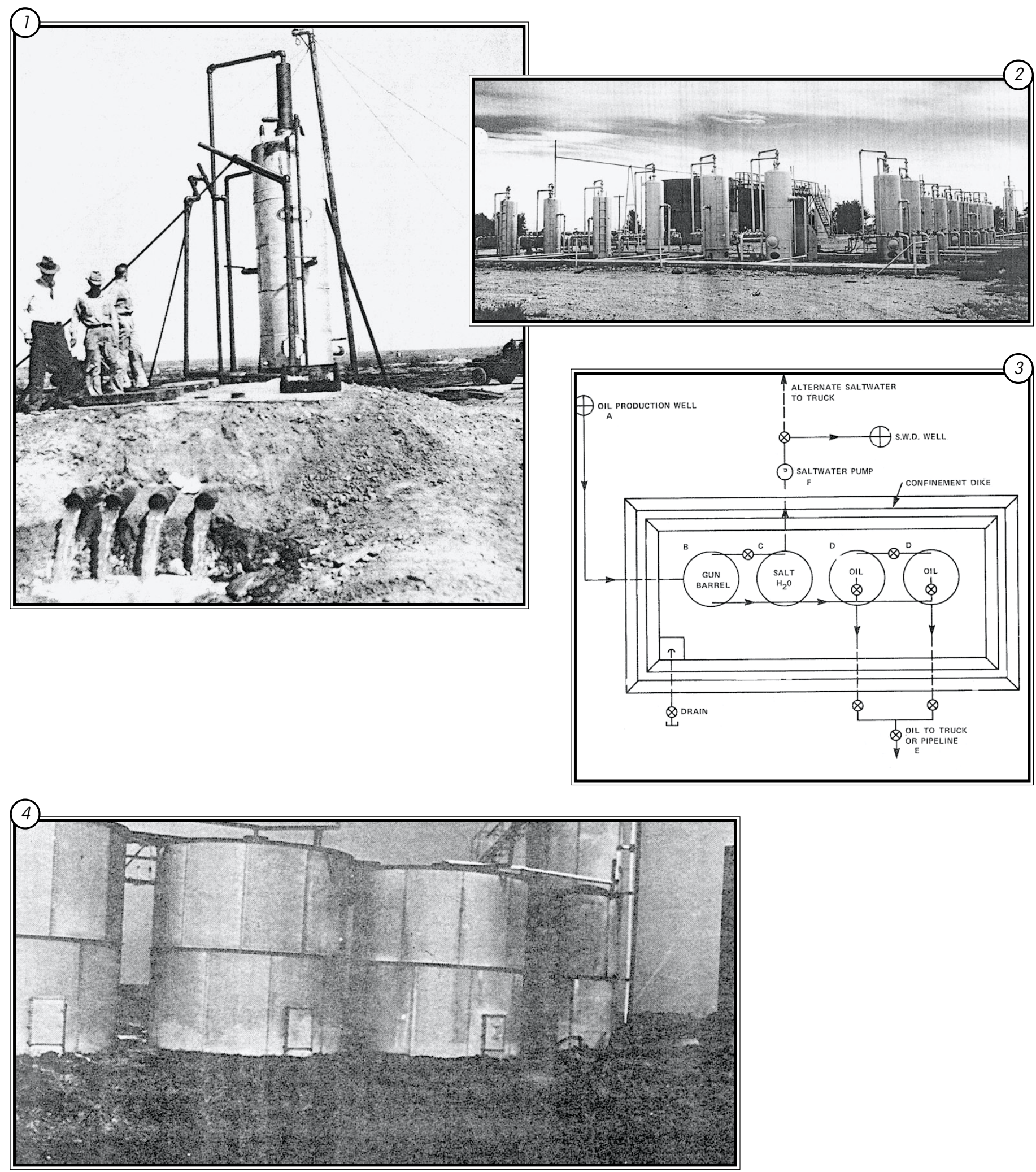

$1 \quad$ This 8x22-ft separator segregated oil, gas, and water, piping the water into a nearby pit in 1938. Daily production from this well was 9,300 barrels of fluid and 500,000 cubic ft of gas that March.

2 A ca. 1945 central separator and metering station monitored production in the Levelland field.

3 This diagram shows the typical configuration of an oil field separator.

4 Commonly seen on the Texas landscape, from left to right, two crude oil tanks, a saltwater tank, a gun-barrel tank, and a heater-treater control this ca. 1980 separator. 


\section{Supply Depots}

\section{Character-defining Features}

- Flat or gable roof

- Concrete foundation

- Steel construction with metal siding or brick construction with brick siding

- Rectangular plan

- Single- or double-door entryway on main façade sheltered by shed roof

- Steel casement or double-hung windows associated with interior office space

- Platforms and loading docks

- Signage identifying associated company and manufacturer

> Railroad sidings or on main railway line

\section{Principal Subtypes}

\section{One-story Supply Depots-}

> One-part commerical-block building

- Sales and office space at front of building with windows that correspond

- Equipment storage towards rear of building

- Platforms and loading docks usually at front of building and may wrap around to side

- Canopies protect platforms and loading docks

\section{Two-story Supply Depots-}

- Two-part commerical-block building, often with one-story rear addition

- Sales and office space on second floor with windows that correspond

- Equipment storage on first floor

- Platforms and loading docks at both front and rear of building

\section{Comments}

Supply depots sell equipment and materials to oil and natural gas operators. Salesmen compete with other local supply depots and have interior office space for show rooms and bookkeeping activities. Windows provide light to office space and sales areas; storage areas are without fenestration. Most of the interior is dedicated to storing a variety of supplies, such as spools of cable, pumps, machinery, and other materials. Salesman can order warehouses, pump houses, tanks, and other buildings and structures from their supplier for distribution to operators.

Early supply depots, constructed of brick, might exhibit modest stylistic influences, most often classically inspired symmetrical fenestration patterns, emphasized cornice and frieze lines, and prominent central entryways. Mid-twentieth-century supply depots are metal and, like the supplies they house, could be purchased from several different manufacturers and assembled on site where signage identified both manufacturer and ownership. These later buildings are strictly functional and any stylistic influences reflect emerging industrial design trends that rejected ornamentation. 

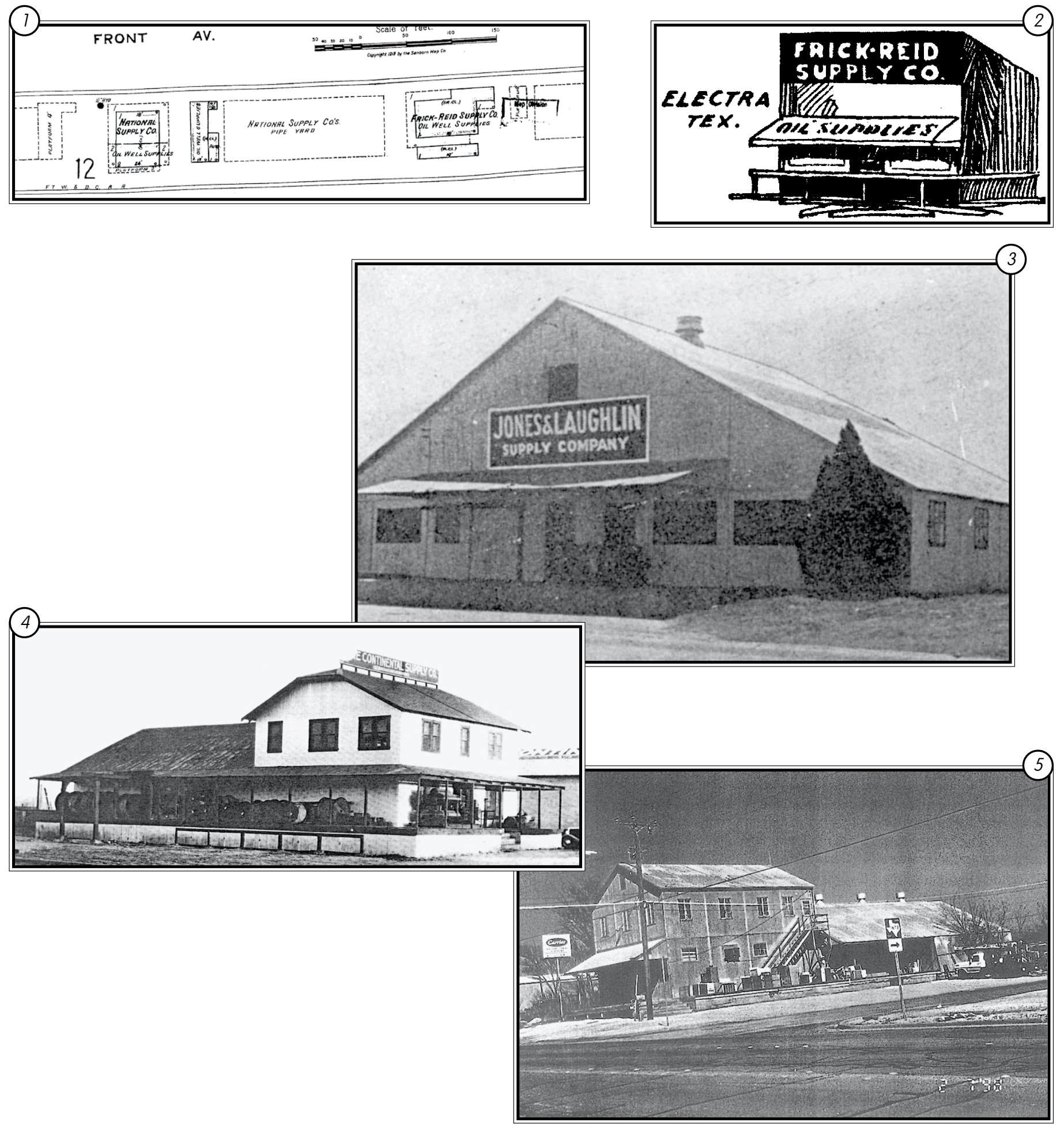

1 In 1919, several oil supply depots, including the National Supply Company and the Frick-Reid Supply Company, lined the block between Front Avenue and the railroad in Electra.

2 A ca. 1920 artist's rendition of the Frick-Reid Supply Company supply depot in Electra shows a one-story building with a canopy covering the front loading dock.

3 The Jones \& Laughlin Supply Company depot opened its first building in Electra in 1911 and replaced it with this ca. 1925 one-story metal building.

$4 \quad$ The Continental Supply Company depot in Odessa opened in 1934. The two-story main building exhibits stylized detailing with clipped gable ends and exposed rafter tails that are reminiscent of Craftsman-influenced design. The loading dock wraps from the front to the side of the building.

5 This ca. 1948 two-story metal supply depot with a one-story addition is in Snyder where oil boomed after World War Il. 


\section{WAREHOUSES}

\section{Character-defining Features}

- Gable roof, although other variations are common

- Concrete foundation

- Steel construction with metal sheathing

- Rectangular plan; sliding metal doors on gable ends large enough for truck access

- Windows, when present, typically are steel casement

- Part of a complex, such as a large bulk terminal plant, supply depot, or refinery

\section{Principal Subtypes}

Truss Construction-

> Roof of traditional truss construction

\section{Clear-span Construction-}

- Roof of "trussless" construction with diagonal rod bracing or arched steel ribs for support

\section{Comments}

Warehouses are most often at large bulk terminal plants, supply depots, and refineries. They frequently house vehicles, maintenance activities, and offices, as well as providing storage space for equipment and products.

Traditional truss construction was most common until the mid-twentieth century. Gable roofs predominated, but common variations included bowstring, multiple gables, two-bay gables, sawtooth, modified sawtooth, monitor, and crane roofs. Truss construction was outmoded with clear-span construction by the 1940s. "Trussless" construction permitted greater overhead clearance within warehouses. Diagonal rod bracing supports the planes of the roof and side walls to insure a rigid frame. Quonset huts are a form of clear-span construction that uses arched ribs of steel to form the side walls and roof.

Warehouses are strictly functional and any stylistic influences reflect emerging industrial design trends that rejected ornamentation. These buildings could be purchased from several different manufacturers and assembled on site where signage identified both manufacturer and ownership. 


\section{WAREHOUSES}
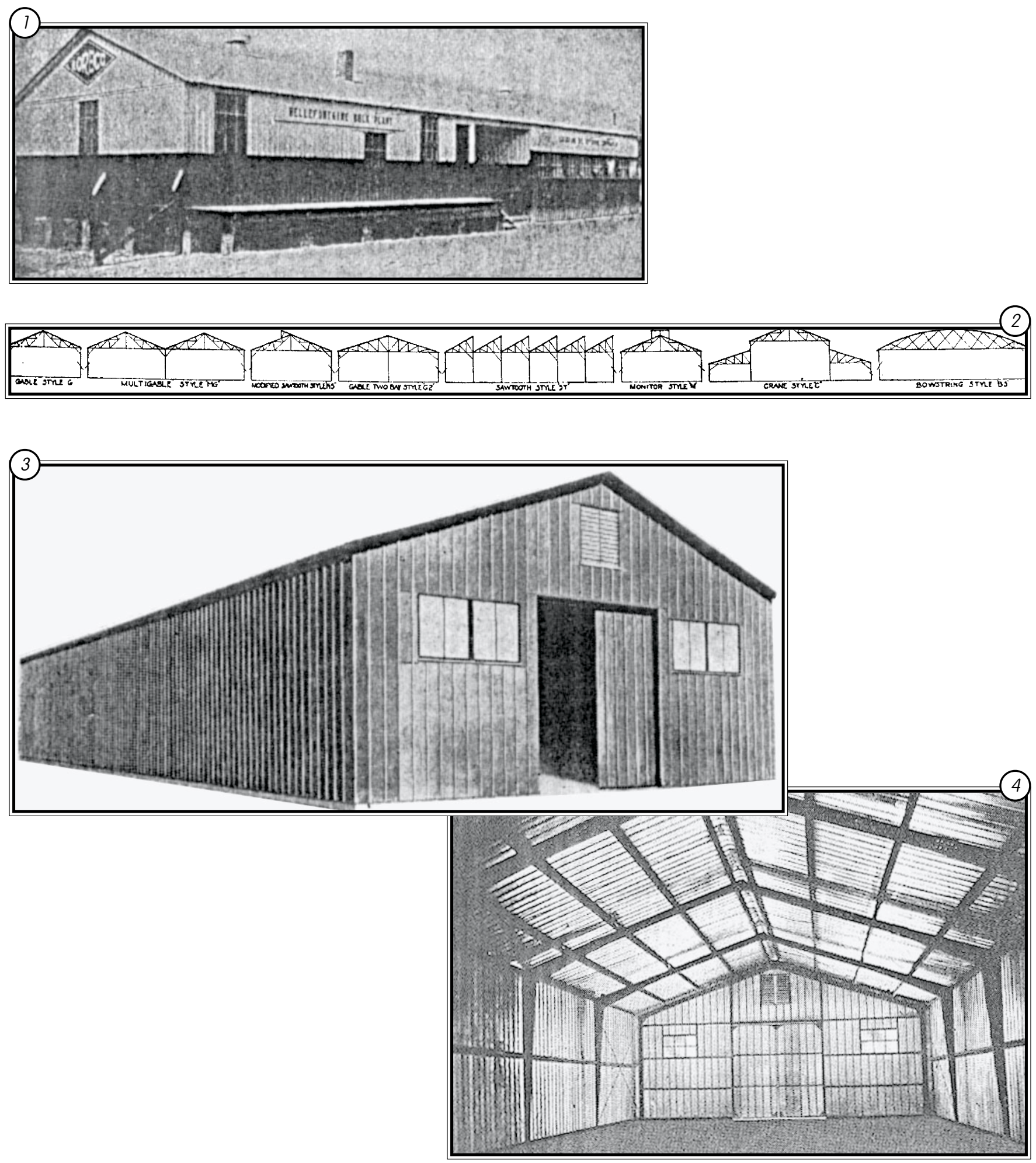

$1 \quad$ Probably serving as both office and warehouse at a bulk terminal plant, this 1929 metal warehouse manufactured by the International Derrick \& Equipment Company utilized truss construction and had a loading platform, a central truck bay, and casement windows.

2 Most manufacturers of petroleum industry buildings offered numerous optional roof forms for truss-constructed buildings. The International Derrick \& Equipment Company marketed these eight styles in 1929.

3 The exterior of the Butler Manufacturing Company's 1946 "trussless" metal warehouse looked no different than a traditional truss-constructed warehouse.

4 Inside, however, the "trussless" rigid-frame warehouse that the Butler Manufacturing Company sold in 1946 allowed more usable vertical space than would a building with trusses blocking the upper portion of the interior. 



\section{Grain Property Types}

Grain production was essential for Texas farmers in the nineteenth and twentieth centuries. Various grains provided food, animal feed, and profit. Up through the mid-twentieth century, corn and wheat were the most significant grain crops.

The state's earliest grain crop was corn, which predates Spanish contact. Native Americans brought corn culture to Texas, and the Spanish missions continued its cultivation. Corn was essential to Anglo-American settlement in Texas, and the newcomers used it for all kinds of foodstuffs and in liquid form as whiskey sour mash. They fed primarily corn to their livestock as grain and silage. All parts of the corn plant, not just the grain, were valued for practical applications. Husks were used to write on, wrap food, and fill mattresses; stalks and leaves served as roof thatch, scarecrows, erosion control, and fencing. By the late nineteenth and well into the twentieth century, farmers grew corn for

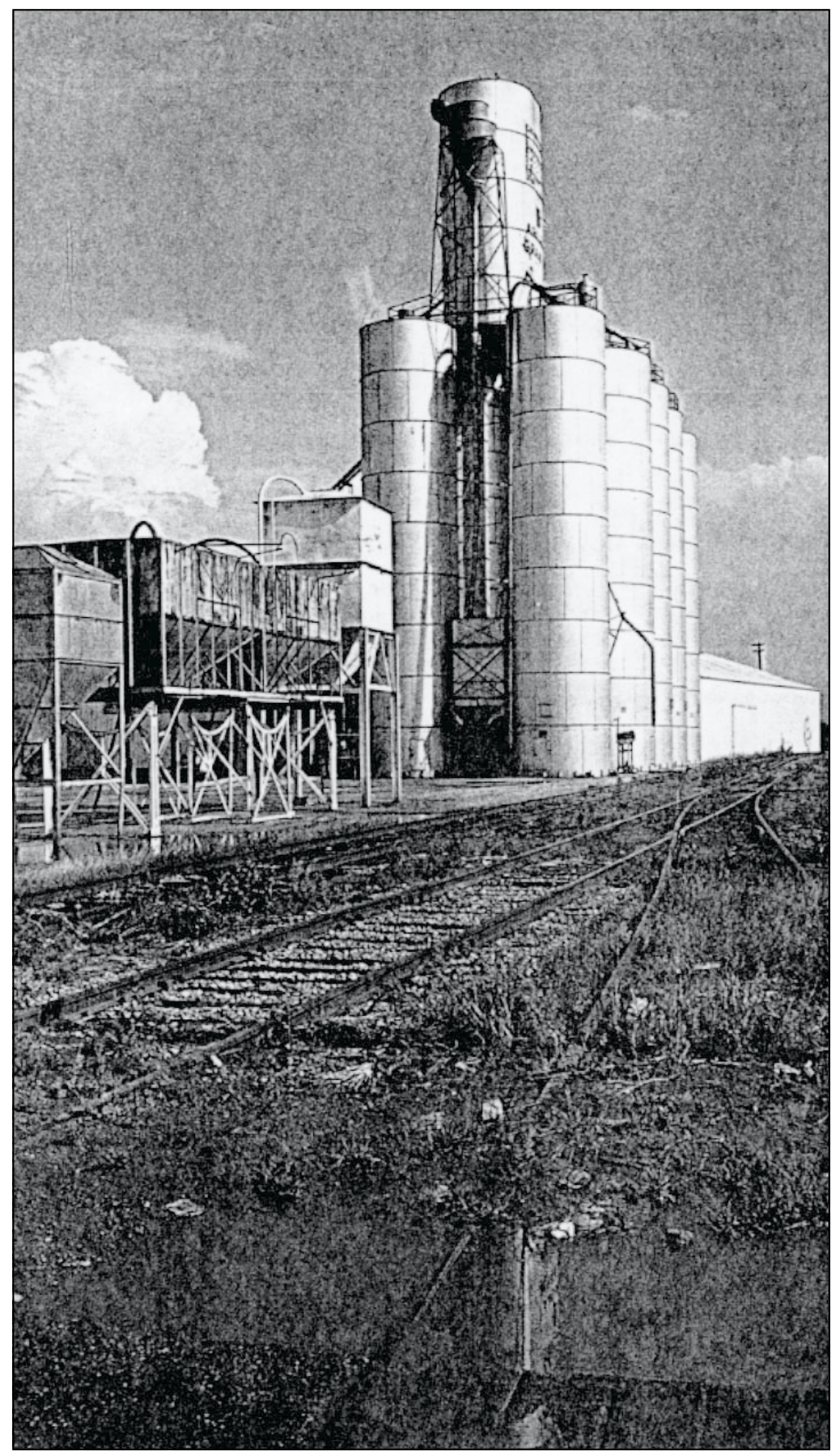
home use and to participate in the ever-grow-

ing market economy. Industrial buildings and structures related to corn production dotted the landscape.

Wheat had somewhat more-limited home use and was not as widely grown in Texas. The first commercially grown wheat was in 1833 in Sherman. By the mid-nineteenth century wheat cultivation had spread to North Central and East Texas. Farmers planted wheat with grain drills and reaped it with machines. Threshers could work up to 300 bushels daily. Production continued to increase through the 1920s. New equipment and varieties of wheat, coupled with rising prices for the grain, shot production up through the mid-twentieth century. By this time the High Plains had become the greatest wheat-producing area in the state and the construction of industrial buildings and structures related to wheat paralleled this movement.

The property types associated with the grain industry and discussed in this field guide are storage complexes, processing complexes, auxiliary buildings, and storage bins. 


\section{Storage Complexes}

\section{Character-defining Features}

- Complex of buildings and structures

- Elevator with headhouse, workhouse, engine-driven or pneumatic leg, and chute

- Storage bins

- Scale room

> Office

- Coal bins or engine shed

- Warehouse

- Driveway to dump pit or boot

- Loading dock and platform

- Signage identifying associated company

- Railroad sidings or on main railway line

\section{Principal Subtypes}

\section{Field Elevators-}

- Small-scale steel elevators and bins

- Include only the essential leg and conveyor mechanism

- No office, scale, or boot

- Minimal storage needs

\section{Country Elevators-}

- Wood, steel, brick, tile or concrete elevators and bins

- Drive sheds

- Engine shed, office, and scale room are frequently housed together

- Some are self-contained systems, others are annexed systems

\section{Terminal Elevators-}

- Concrete elevators

- Huge concrete storage and work bins

\section{Comments}

Storage complexes offer a simple means of receiving, storing, and shipping bulk grain, particularly small cereal grains such as wheat, corn, oats, barley, milo, and soybeans, to distant markets. The elevator, also known as the main house, has a headhouse atop, a workhouse at its base, and an engine-driven or pneumatic leg whose drive shafts move one or more vertical belts and bucket conveyors to the headhouse. Processed grains exit through a chute, which faces the railroad siding. Grain storage complexes are strictly functional and any stylistic influences reflect emerging industrial design trends that rejected ornamentation.

Farmers occasionally install their own field elevators with a few small steel bins near rail lines. They may use the raw grain for seed or feed, but more often they ship these small quantities to country elevators.

Country elevators serve local farmers who deliver their harvest to elevators in small towns and county seats. Country elevators weigh, clean, and store the grain before it is transported by railroad to terminal elevators. At country elevators, farmers bring a wagonload of grain to the drive shed where it is protected from weather conditions. There they have it weighed and unloaded into a dump pit (also known as a boot) from which a conveyor carries the grain to the top of the elevator. The leg distributes the grain to work and storage bins. Country elevators were commonly of wood, steel, brick, or tile construction through the 1930s, when concrete became the more predominant material. Some country elevators are self-contained systems with constituent parts in the main house, others are annexed systems with elevating machinery in the main house and storage 


\section{StoRAGe CompleXes}

bins connected with conveyors and external spouts. An independent company, a larger terminal elevator company, a cooperative, or a wheat pool might own a country elevator.

Grain is shipped from country elevators to large, concrete terminal elevators in major transportation centers. Terminal elevators are equipped to clean, clip, dry, grade, mix, store, and sack raw grain and grain products. From terminal elevators, unprocessed or minimally processed grain is loaded onto railroad cars or ships and sent to large mills; grain products are transported to distribution and consuming centers. Terminal elevators operate at a much greater capacity and charge higher rates for storing grain than do country elevators. A large independent company or railroad line usually owned terminal elevators.
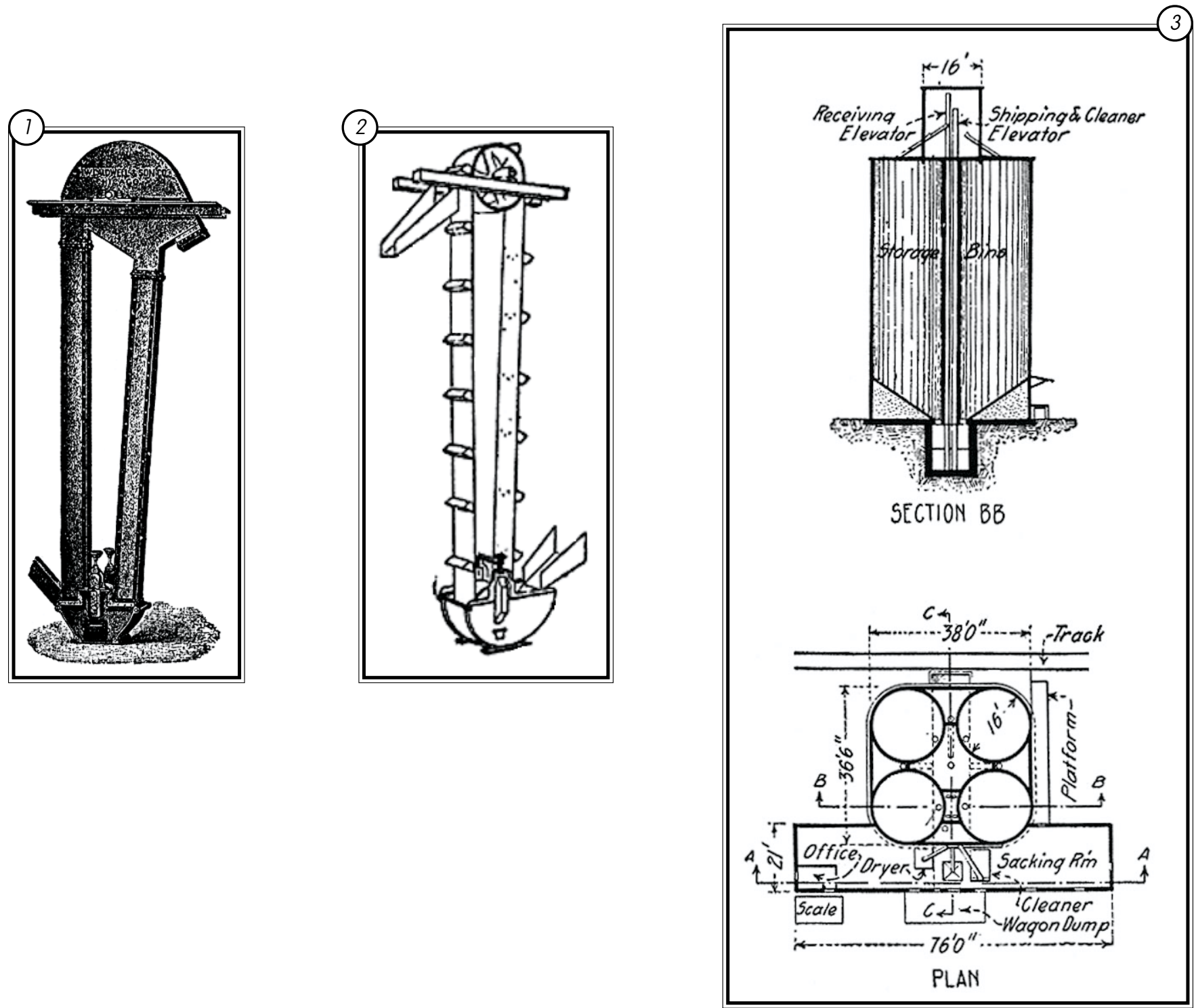

1, 2 These 1911 drawings show a prototypical elevator leg (1) and belt elevator (2).

3 This plan and section of a 1911 reinforced concrete country elevator was very early for its time because wood, steel, brick, and tile were the most common materials used until the 1930 s. 


\section{Storage Complexes}

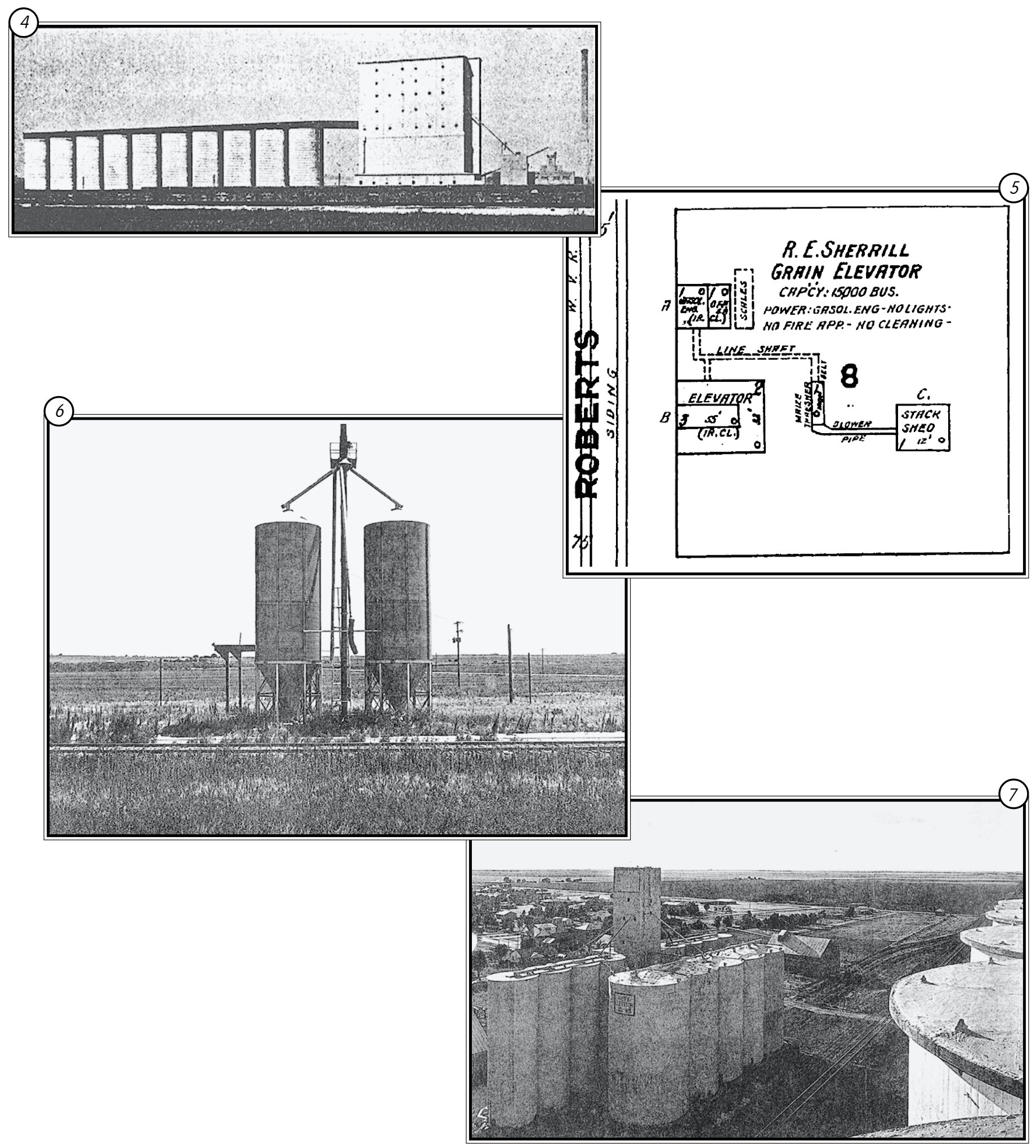

$4 \quad$ The Missouri Pacific Railway owned and operated this concrete terminal elevator in Kansas City in 1911.

5 R. E. Sherrill's ca. 1913 country elevator in Haskell had a gas-driven engine and a 15,000 bushel capacity.

6 This ca. 1940s steel field elevator along a railroad line near Roscoe has the essential components: a leg and conveyor mechanism with two small storage bins.

$7 \quad$ The view looking north from the 1945 Harmon-Toles country elevator in Happy shows this concrete elevator's square main house is central to 10 concrete storage bins. 


\section{Processing Complexes}

\section{Character-defining Features}

- Wood or concrete mill building

- Single-sided or double-sided

- Elevator within mill with headhouse, workhouse, engine-driven or pneumatic leg, and chute

- Scale room

> Office

> Engine shed

- Workbins

- Various chutes, discharge spouts, and related docks and platforms

- Warehouses

- Testing laboratories at larger facilities

- Cleaning equipment such as dampers, washers, and dryers

- Packing spouts and machines for packaging

- Driveway to dump pit or boot

- Water tower

- Signage identifying associated company

- Railroad sidings or on main railway line

\section{Principal Subtypes}

\section{Feed Mill Elevators-}

- Specialized machinery including sifters, scalperators or plansifters, and aspirators

- Seed-cleaning equipment in some mills

> Small storefront operations

\section{Flour Mill Elevators-}

- Specialized machinery including sifters, scalperators or plansifters, and aspirators

- Specialized machinery including roller mill and reduction roller mill

\section{Comments}

Farmers bring their grain to processing elevators that serve local or regional areas. The grains are broken, scalped, reduced, divided by grade, and packaged into flour or feed. Feed tends to be distributed locally, while flour more commonly is sold to both local and more-distant markets. Flour and feed mills often are combined within a single operation, although some remain exclusive to one activity. Some mills are single-sided with elevators in a row along one wall and machinery extending the width of the building; others are double-sided with central elevators and machinery surrounding them. In either case, elevators have a headhouse atop, a workhouse at the base, and an engine-driven or pneumatic leg whose drive shafts move one or more vertical belts and bucket conveyors to the headhouse. These buildings and structures are strictly functional and any stylistic influences reflect emerging industrial design trends that rejected ornamentation.

Feed mill elevators process a variety of different grains. After being dumped, weighed, cleaned, and graded, feed grain is transported vertically and horizontally from holding bins to a grinder. Corn, for example, is shelled and crushed, the cob is crushed, and all particles are conveyed to a roller mill where they are further refined. These particles are then aspirated with a suction device and augered to an overhead bin, which spouts the meal into 100-lb sacks. Sometimes, after aspiration, corn is blended with other grains and mineral supplements as per customer specifications, and then sacked. The finished product is stored in a warehouse and sold to local customers or sent to other markets. Feed mill elevators must be organized so that a maximum number of varioussized work bins can accommodate different types of grains. Bins are spaced apart to provide for more interstice 
bins. Chutes, discharge and packing spouts, packaging machines, and related docks relevant to processing, packaging, and distributing feed stuffs are particular to this type of mill. Feed mill elevators may also include seed-cleaning equipment. Often, they have small storefront operations from which they market feed products.

Flour mill elevators process wheat. The wheat is weighed, broken in a roller mill on the first or second level, sifted on the third level, cleaned with a scalperator or plansifter and dried with a damper on the fourth level, reduced with a reduction roller mill or aspirator on the fifth level, and centrifuged on the sixth level, where dust is collected. The processed wheat is then fed to a revolving telescopic spout and distributed to holding bins. The bins release wheat to be weighed again, blended, and conveyed to storage bins.

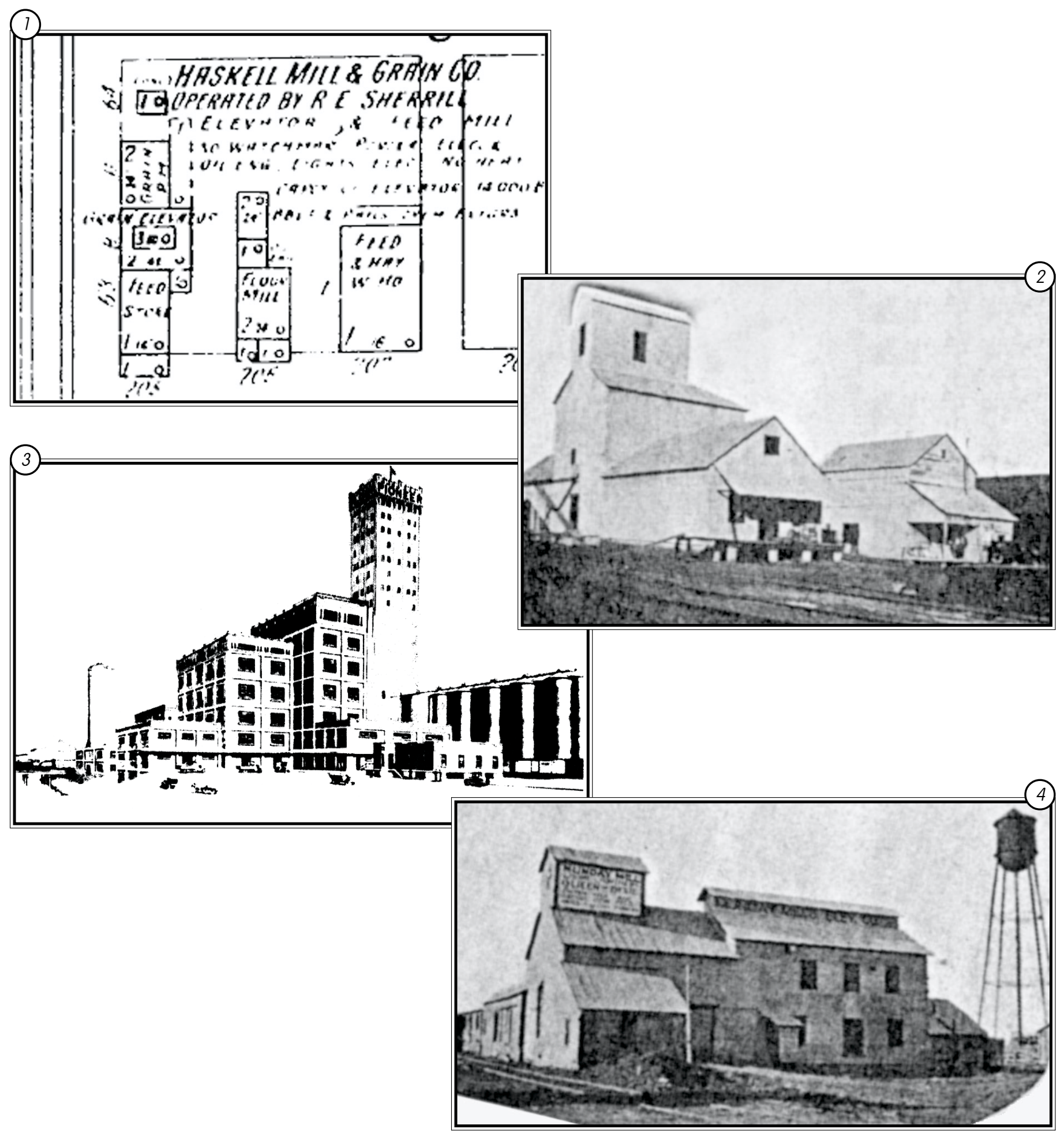




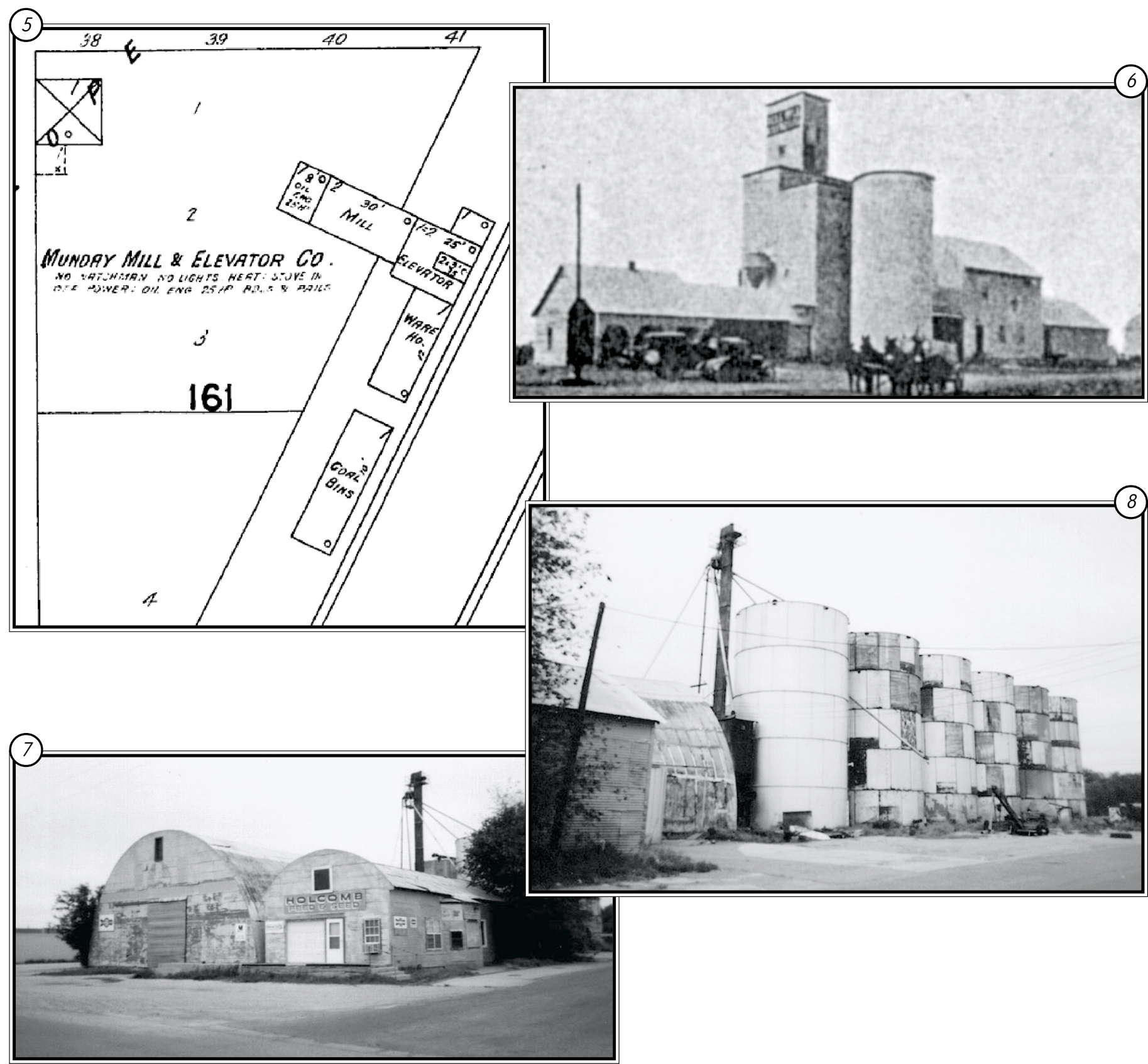

1 In 1913, R. E. Sherrill operated a wood grain elevator in Haskell that had an office, scales, and a maize thresher. A gasoline engine drove the elevator, which could process 15,000 bushels of grain.

2 By 1927, Sherrill had expanded his elevator to a full service mill and grain company that had a grain pit, elevator, feed store, flour mill, and warehouses. The elevator looms behind the feed store on the left with the flour mill on the right.

3 Pioneer Flour Mills in San Antonio was a very large concrete processing facility in 1915.

$4 \quad$ Small-town mills like the ca. 1920 Munday Mill \& Elevator Company were typically wood buildings. A water tower is on the far right.

5 By 1925 a 25 horse-power oil engine drove the elevator at Munday Mill \& Elevator Company, but a large area set aside for coal bins hearkened back to an earlier time when steam powered the operation.

6 Constructed by 1921, the Bell Mill \& Elevator Company in Crowell was an early example of a processing complex made of reinforced concrete.

$7 \quad$ A feed mill had been on this site in Lamesa for some time, but the Quonset-hut style of these warehouses probably dates to the late 1940s. The protruding tripartite bay on the north elevation and gable roof (hidden behind the rounded gable end) indicate that the warehouse to the right is substantially older despite later changes to the main façade.

Behind the Lamesa warehouses, the elevator connects with six steel tanks. 


\section{Auxiliary BuIldings}

\section{Character-defining Features}

- Wood, brick, metal, or concrete building

- Usually rectangular plan

- Usually gable roof

- Part of storage or processing complex

\section{Principal Subtypes}

\section{Office Buildings-}

- Small, one-story building

- Square or rectangular plan

- Gable or hipped roof

- Interior may include reception, bookkeeping, management, weighing and testing, and display areas

- Frame sash or metal casement windows

- Some offices are contained within a warehouse

\section{Warehouses-}

- Gable roof of truss or clear-span construction

- Wood or concrete piers with plank or concrete slab flooring

- Typically 50x150 ft

- Truck bays on at least one façade

> Some warehouses include an office

\section{Comments}

Office buildings serve the business needs of grain complexes. They house bookkeeping and management employees and offer reception and display areas for showcasing products to customers. Usually office buildings have windows to both provide interior light and to allow the manager a view of the facility's operations, particularly the scale. Late-nineteenth- and early-twentieth-century office buildings may exhibit modest stylistic influences, most often classically inspired symmetrical fenestration patterns, emphasized cornice and frieze lines, and prominent central entryways. Those constructed in the 1920s and 1930s may exhibit Craftsman, Art Deco, or Art Moderne attributes. Office buildings constructed in the mid-twentieth century likely employ International Style design principles.

Warehouses store overflow grain during peak harvest season, seed-cleaning operations, retail products, or plant vehicles and equipment. Warehouses can also be used for packing feed or flour. These buildings are strictly functional and any stylistic influences reflect emerging industrial design trends that rejected ornamentation. 

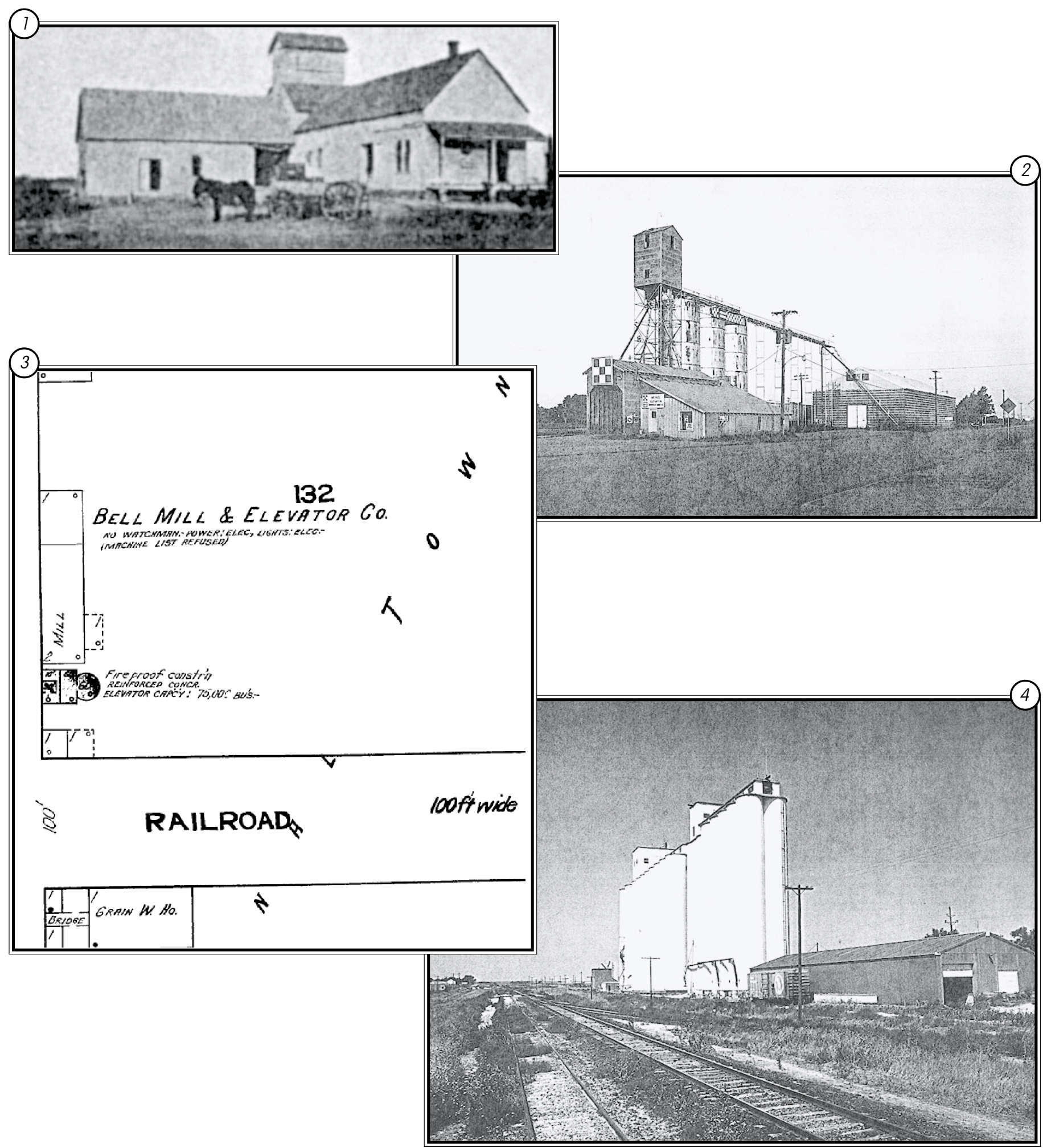

1 The windows on the one-story wood office building in the foreground at Knox City Elevator reveal the location of office space, 1927.

2 A small wood office building with shed roof, in the foreground, and a larger metal warehouse in the background, both ca. 1930s, surround this steel elevator in Merkel.

3 The Bell Mill \& Elevator Company, powered by electricity, could produce 75,000 bushels of grain. The company had a grain warehouse across the street from the elevator.

4 A ca. 1930s metal warehouse in the foregrounds flanks the elevators in Follett. 


\section{Storage Bins}

\section{Character-defining Features}

- Cylindrical or rectangular

- Concrete foundation

- Connected to elevators with conveyor gallery above and tunnel conveyor below bin

- Part of storage or processing elevator complex

\section{Principal Subtypes}

\section{Wood Storage Bins-}

- Usually rectangular

- Up to five stories in height

- Studded bins: base of heavy posts and girders

upper stories are balloon-frame construction

tie rods anchored to horizontal braces on exterior walls

- Cribbed bins: base and walls of 2-inch-thick wood planks from 4 to 10 inches wide

planks laid flat atop each other

- Galvanized corrugated tin or iron exterior walls

- Metal or wood lid

\section{Steel Storage Bins-}

- Cylindrical or rectangular

- Height of 30 to $80 \mathrm{ft}$

- Cylindrical diameter of 15 to $45 \mathrm{ft}$, rectangular with dimensions of $14 \times 18 \mathrm{ft}$

- Square or rectangular steel plates bolted or riveted together

- Z-bar reinforcements overlap in single, double, or triple joints

- Interiors grouted with cement and sand mixture, primed with iron oxide, and top coated with white paint and linseed oil mixture

- Conical or flat steel lid

\section{Tile Storage Bins-}

- Cylindrical

- Hollow clay tiles, two-courses deep, reinforced with steel

- Semiporous tiles are $12 \times 12 \times 6$ inches with semiporous channel tile layer between each row Channel tile is $12 \times 4 \times 5$ inches with vertical steel reinforcing bands

- Outside facing tile is $12.0 \times 12.0 \times 1.5$ inches and semiglazed

> Wire netting bonds bin wall to outside facing tile

> Tile lid with cement mortar

\section{Brick Storage Bins-}

- Cylindrical or rectangular

- Cylindrical bins: brick walls three-courses deep bonded two inner courses and outer course spaced about two inches apart wire bonds connect outer to inner courses vertical steel reinforcements about every 12 inches

- Rectangular bins: brick pilasters at outside corners columns at interior corners steel reinforcements span from corner to corner along wall planes arched brick siding with concave shape facing outward

- Metal or concrete lid 


\section{StORAGE BINS}

\section{Concrete Storage Bins-}

- Cylindrical

- Diameter of 15 to $25 \mathrm{ft}$

- Height of 50 to more than $100 \mathrm{ft}$

- Concrete walls from 6 to 8 inches thick with both horizontal and vertical steel rod reinforcements

- One or two doors allow entrance to bin at base

- Flat concrete lid

\section{Comments}

Storage bins, also known as tanks or towers, were commonly constructed to meet additional storage needs of grain facilities, especially during peak harvest periods. This additional storage space saved local farmers the expense of housing their grain at terminal elevators and afforded them the opportunity to await favorable price increases during the off season.

Wood storage bins are seen only at late-nineteenth- and early-twentieth-century complexes. The tie rods of studded wood bins, anchored to horizontal braces on exterior walls, are distinctive to studded wood storage bins. Cribbed storage bins required a lot of wood for the horizontal arrangement of planks. The cribbed construction method allowed bins to reliably bear the tremendous pressure that large quantities of grain exerted. Steel storage and tile bins were common through the mid-twentieth century. Concrete storage bins became increasingly common after the early 1920s, when technical knowledge of slip-form construction became more widespread. This method of construction was preferable because of its durable, fireproof, rodent-proof qualities, which saved operators in terms of insurance, spoilage, and damage to grain. These structures are strictly functional and any stylistic influences reflect emerging industrial design trends that rejected ornamentation.

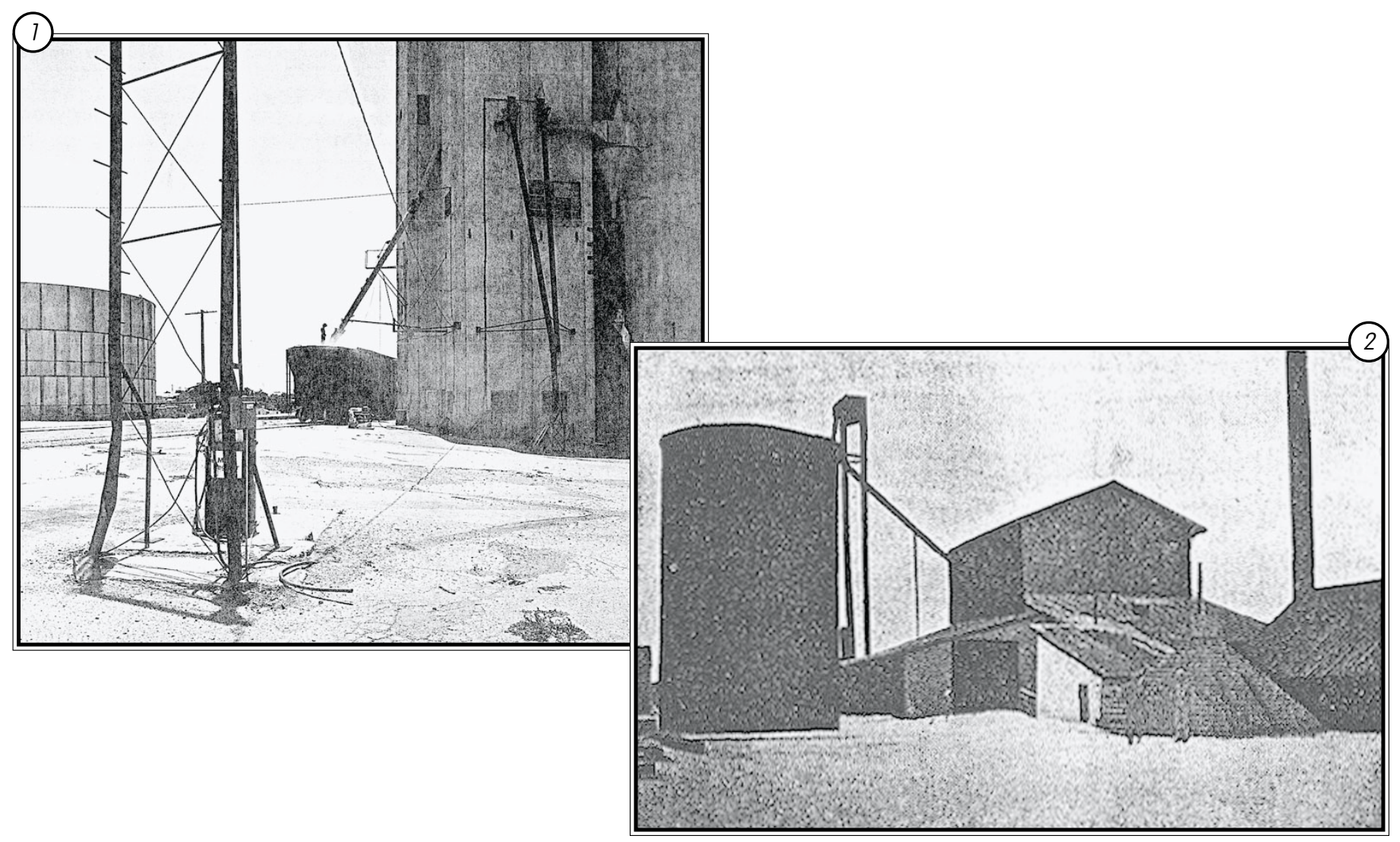

1 A ca. 1920s cylindrical steel storage bin is to the far left and a ca. 1930s concrete storage bin is to the right in Brownfield.

2 At the far left is a ca. 1900 rectangular steel storage bin with a tall elevator leg just behind it. 

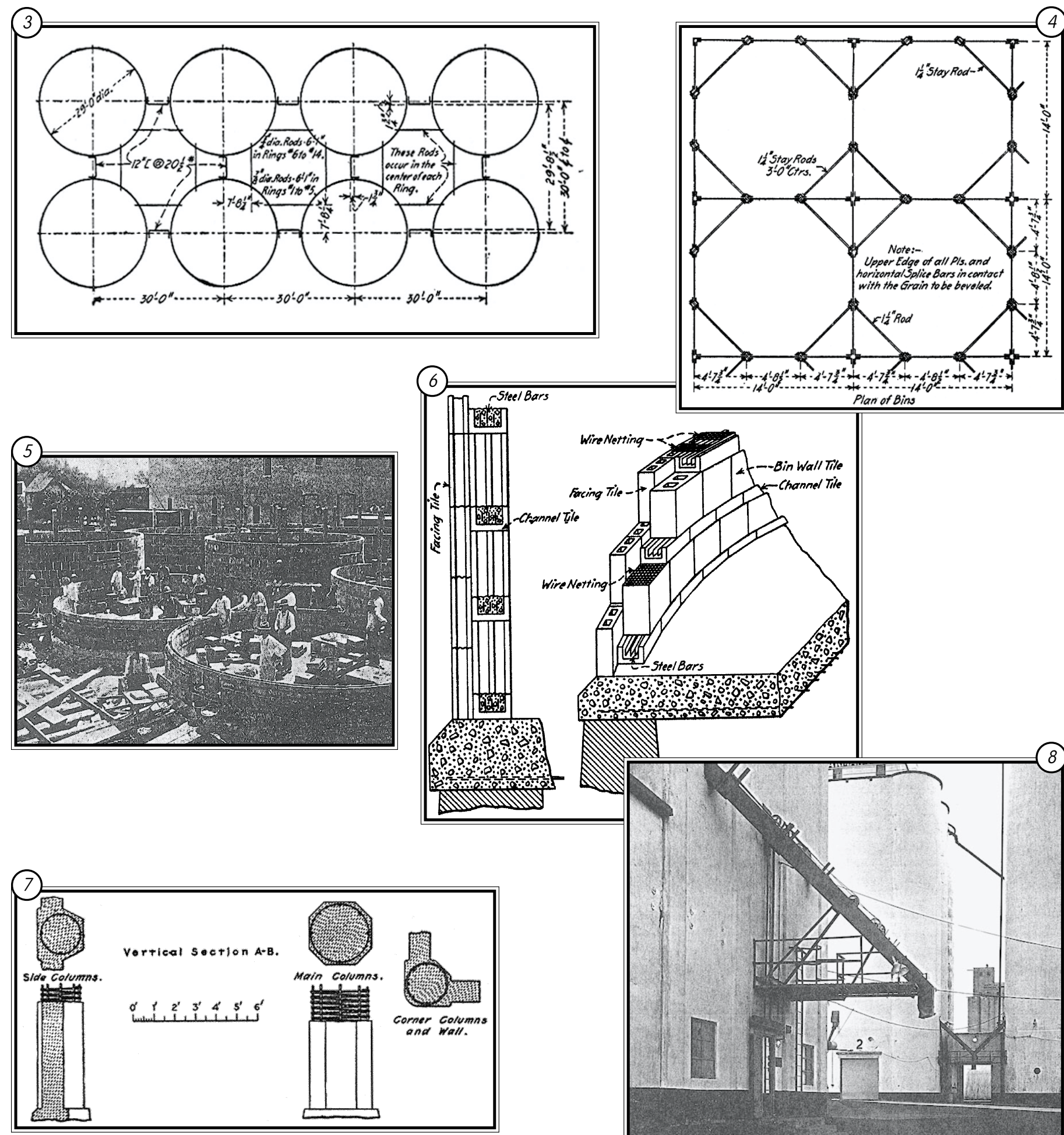


\section{Cotton Property TYPES}

Cotton was first grown in Texas in the eighteenth century, when Spanish missions produced the crop. Anglo-American colonists grew cotton as early as 1821 , and production continued to rise during the nineteenth century, with the ex-

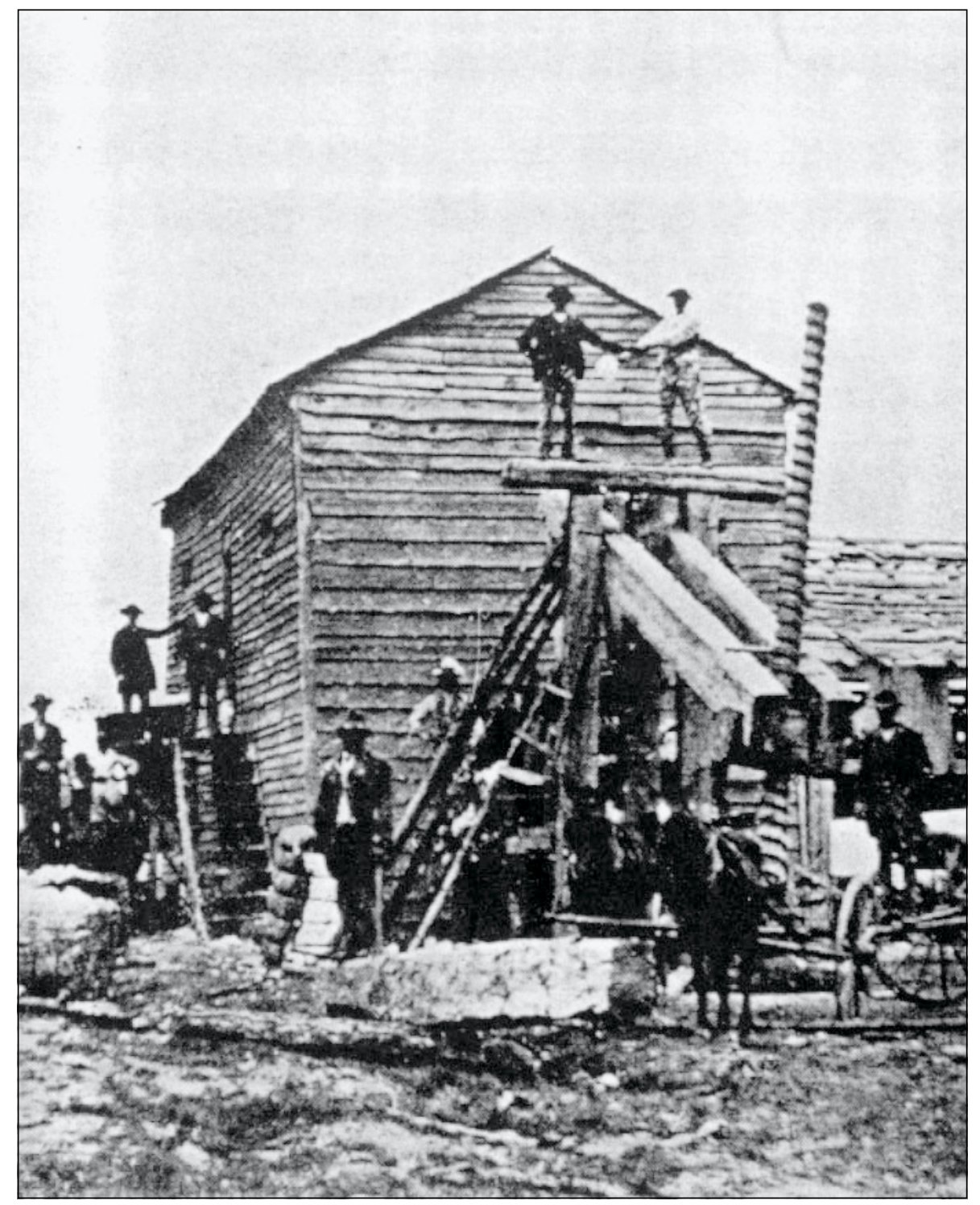
ception of the Civil War years. Slave labor was critical to cotton production prior to the Civil War and, in its aftermath, tenants, sharecroppers, and landowners alike sowed, cared for, and picked cotton.

Increased cotton production encouraged technological progress for processing the fibers. Cotton gins, the abbreviated term for cotton engines, separate seeds from the fibers, or lint, in which they are embedded. Robert S. Munger of Mexia advanced the ginning system from animal power to automation in 1884. The baling process also underwent transformation so that bales could be more tightly compressed and greater quantities could be transported via rail or ship.

Neither technological progress nor demand for cotton could prevent the boll weevil from ravaging Texas cotton crops in the 1890s and into the twentieth century. The devastation resulted in pesticides to control insects. At the same time, county extension agents were setting up experiment stations and, later, demonstration farms to show farmers improved crop cultivation methods.

Demand for cotton in the early twentieth century continued to increase through World War I, but notable changes took place in the postwar era. Prices dropped so low that tenants and sharecroppers had to largely abandon the crop. The federal government reduced cotton acreage by half with its control program. Foreign production increased substantially, gouging Texas's cotton export market. In addition, synthetic fibers, tariffs, the Great Depression, and another world war made cotton less profitable. 
By the mid-twentieth century, fewer but larger farms with less workers and more machines characterized cotton production. The crop and its growers benefited from irrigation, erosion control, pest and insect management, and mechanical harvesting. Cotton culture, once concentrated in East and Central Texas, shifted to the High Plains and the Rio Grande Valley. Thus, construction of industrial buildings and structures related to cotton paralleled this movement.

The property types associated with the cotton industry and discussed in this field guide are gin plants, cottonseed oil mills, cotton houses and warehouses, seed storage facilities, and trash collection facilities. 


\section{Gin Complexes}

\section{Character-defining Features}

- Complex of buildings and structures

- Wood-frame, brick, or metal gin house

- Interior includes gin, press, seed, and lint rooms

- Office with wagon scale

- Wagon shed

- Power plant

- Cotton house

- Bale platform

- Seed storage with corresponding conveyors from gin house

- Trash collection

- Baghouse

- Sidelines such as service stations and cold storage at some locations

- Water tower, tank, or well

- Railroad sidings or on main railway line

\section{Principal Subtypes}

\section{Two-story Gin Houses-}

- Two-story, wood-frame or brick building housing ginning equipment

- Earthen or wood flooring

- Hand-, animal-, or coal-powered steam engines

- Boilers and coal sheds or bins

\section{One-story Gin Houses-}

- One-story, masonry or metal buildings housing ginning equipment

- Earthen or concrete flooring

> Oil- or electric-powered engines

\section{Comments}

Cotton gins separate seeds from the fibers, or lint, in which they are embedded. Gin houses constructed from the nineteenth century through about the 1920s were usually two-story wood or brick buildings. Stylistic influences might nominally reflect classically inspired detailing such as symmetrical fenestration patterns, emphasized cornice and frieze lines, and prominent central entryways. Farmers delivered wagonloads of cotton to gin plants, had their product weighed on wagon scales, usually at or near the office, and then drove them under the wagon shed of the gin house. The cotton was elevated to the second level and hand fed to the gin. The gin discarded seeds into first-level containers and dumped lint into an area on the second level for packaging and baling. Bales were moved to a loading dock, placed on wagons, and shipped to textile mills. These early gins were powered by hand-, horse-, and coal-operated steam engines that required boilers and coal sheds or bins on site. Ginners, to catch up with technology, integrated new or used equipment within their older two-story facilities without changing the exterior appearance of the gin houses.

By the mid-1920s, newer gin models required more-secure mounting with less vibration, and one-story buildings were most efficient in this cause. Gin manufacturing companies sold not only new gins and equipment, but pre-fabricated buildings to house the machinery. These buildings and structures are strictly functional and any stylistic influences reflect emerging industrial design trends that rejected ornamentation. They were constructed of masonry or metal and had earthen or concrete flooring, which reduced the risk of fire hazard. Increasingly, oil or electricity was the common power source, requiring changes to extant power rooms, but 


\section{Gin Complexes}

eliminating the need for coal sheds. New pieces of equipment became important by the mid-twentieth century, particularly metal gin stands and artificial drying equipment. Modernization introduced pneumatically mecha-

nized handling systems.
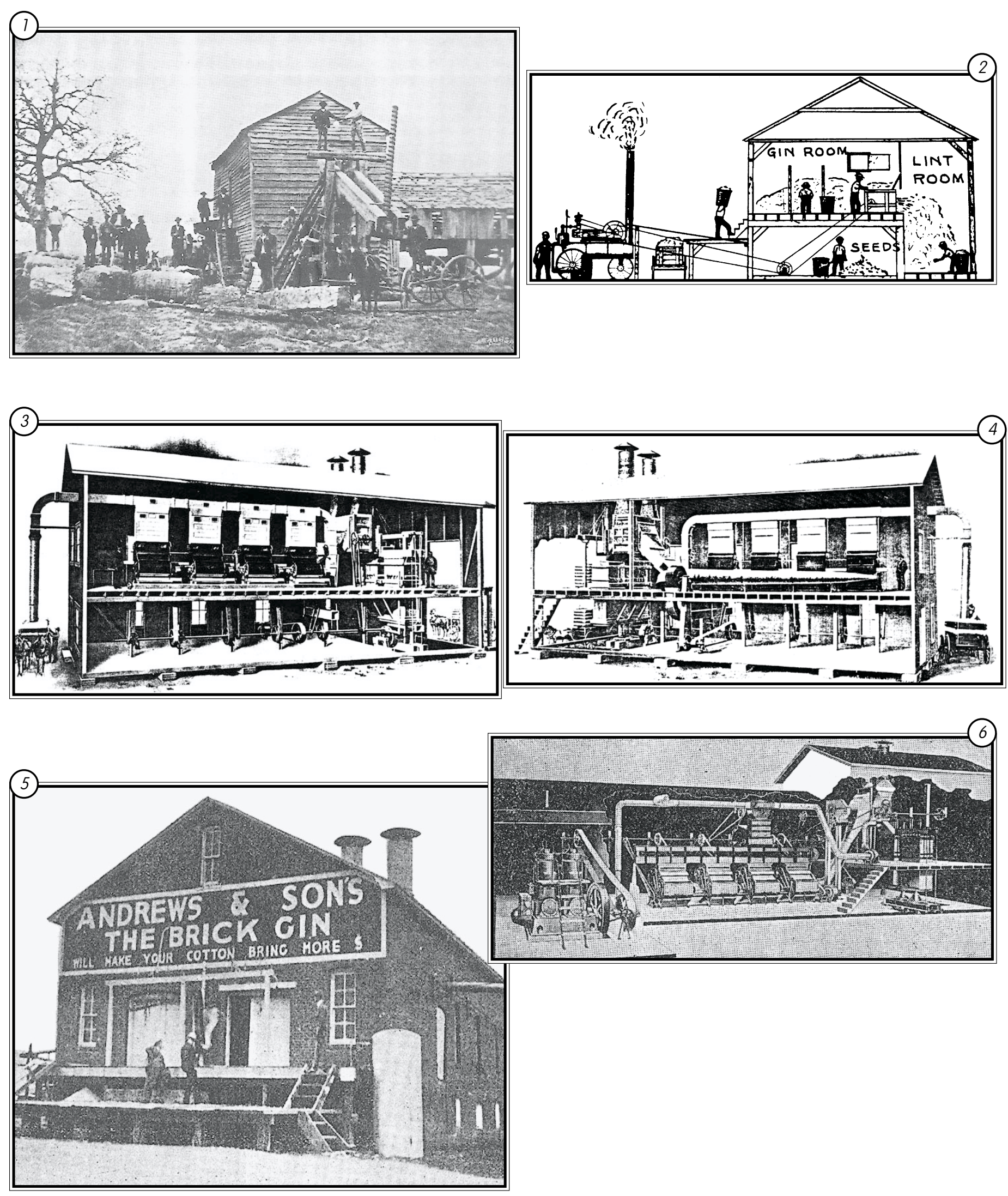


\section{GiN COMPLEXES}
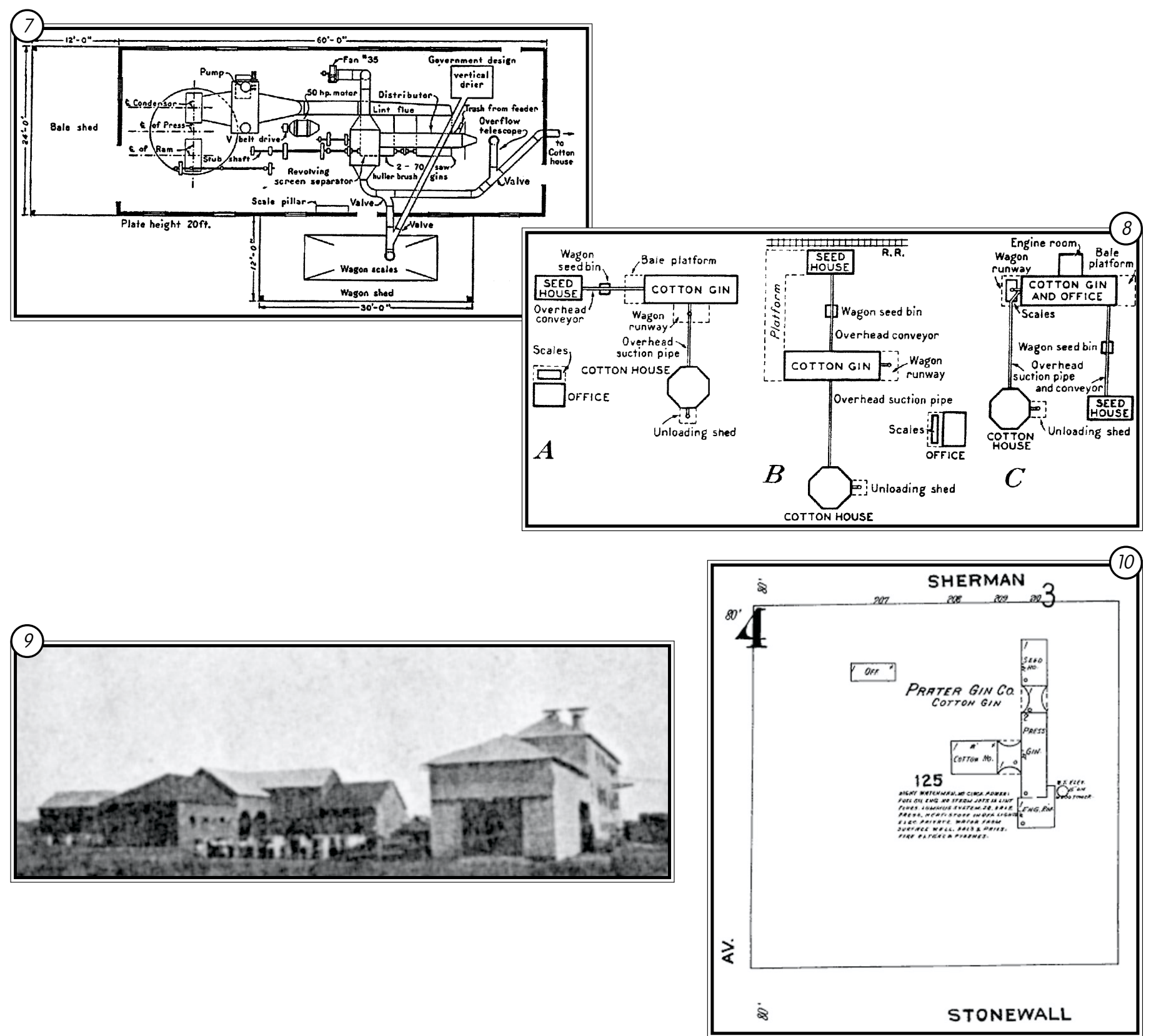

$1 \quad$ This two-story wood gin house and mule-powered screw press in East Texas date to the 1850s.

2 A steam-operated tractor powered a single stand gin in the ca. 1890 two-story gin house depicted here. Workers unload the cotton by hand and carried it to the gin room for processing. Cotton byproducts, lint and seeds, were sent to separate rooms. The processed cotton was pressed into bales in the gin yard.

3, 4 The front view (3) of this 1909 Lummus steam-powered gin and system in a two-story building shows a four-stand system, while the rear view (4) exposes the lint flue behind the gin stands, condenser, and bale press.

5 Built in 1900, this classically inspired, two-story brick gin house in Waxahachie has a prominent bale platform on the front elevation. The building housed nine gin stands.

6 With the advent of modernization, one-story gin houses became more practical. This ca. 1927 cutaway reveals placement of four gin stands in an oil-driven gin house.

7 A 1935 floor plan illustrates equipment placement in a one-story gin house

8 Placement of the gin house at the gin plant could be handled several ways, all of which are intended to minimize the likelihood and consequences of fire, as these three possible arrangements show.

9 The ca. 1922 Prater Gin Company in Rotan is an example of a basic gin plant with a two-story gin house that had a press room and an engine room. The plant also had a seed house, cotton house, office, and water tower.

10 An oil-driven engine powered the Lummus gin system and a square bale press at the Prater Gin Company. The office was sited away from the gin house to prevent the spread of fire. 


\section{Cottonseed Oil Mills}

\section{Character-defining Features}

- Complex of buildings and structures

- Wood-frame, metal, or masonry mill building

- Interior includes boiler room, engine room, press room, separating room, meal room, linter room, and linter press room

- Hull house

- Seed house

- Linter shed

- Bagging house

- Mixed feed building

> Cottonseed oil tanks

> Office

- Sheds and shop buildings

- Water tower

- Railroad sidings or on main railway line

\section{Principal Subtypes}

\section{Country Mills-}

- Close to cotton fields and adjacent gins

- Small facilities with one to seven presses

- Sometimes an on-site dwelling for mill supervisor

- Sidelines such as ice, fertilizer, or lint processing

\section{Terminal Mills-}

> In major railway centers

- Large facilities with eight or more presses

\section{Comments}

Cottonseed oil mills separate the inner pellet of cottonseed from the hulls and lint. This "meat" is then crushed and again separated into oil and meal. The oil is used in a variety of food products, and the residue is pressed into cottonseed cake or meal that is fed to livestock. The cottonseed oil mill industry grew in conjunction with cotton production in Texas. The number of mills was only 4 in 1879, peaked at 200 in 1929, declined to 144 in 1940, and decreased to 95 in 1950. Although fewer cottonseed oil mills remained extant at mid century, those that still functioned were generally larger country mills or terminal mills.

Country mills sold cottonseed cake and meal to local farmers at higher rates than terminal mills. Locally produced cake and meal was higher quality since it suffered none of the damage transportation might cause. The oil that country mills produced weighed substantially less than raw cottonseed, so transportation costs to refineries were reduced. Country mills were relatively small operations, having one to seven presses and minimal storage capacity. A single mill might press up to 100 tons of cottonseed daily during the fall season. Many country mills had, in addition to the mill building and its subsidiaries, an on-site dwelling where the mill supervisor lived. Country mills also might operate sidelines, such as ice, fertilizer, insecticide, or lint processing, since local cottonseed production season was isolated to a few months each year. Country mills might be independently or cooperatively owned.

Terminal mills sold cottonseed cake and meal to country mills and feed mills at cheap rates. Terminal mills' profit margin came from sales of cottonseed oil. They acquired cottonseed from near and distant country cotton gin complexes and distributed processed oil to refineries. Terminal mills would have eight or more presses, and 


\section{Cottonseed Oil Mills}

press 100 to 250 tons of cottonseed daily during the season. Large refining and manufacturing companies owned most of the terminal mills.
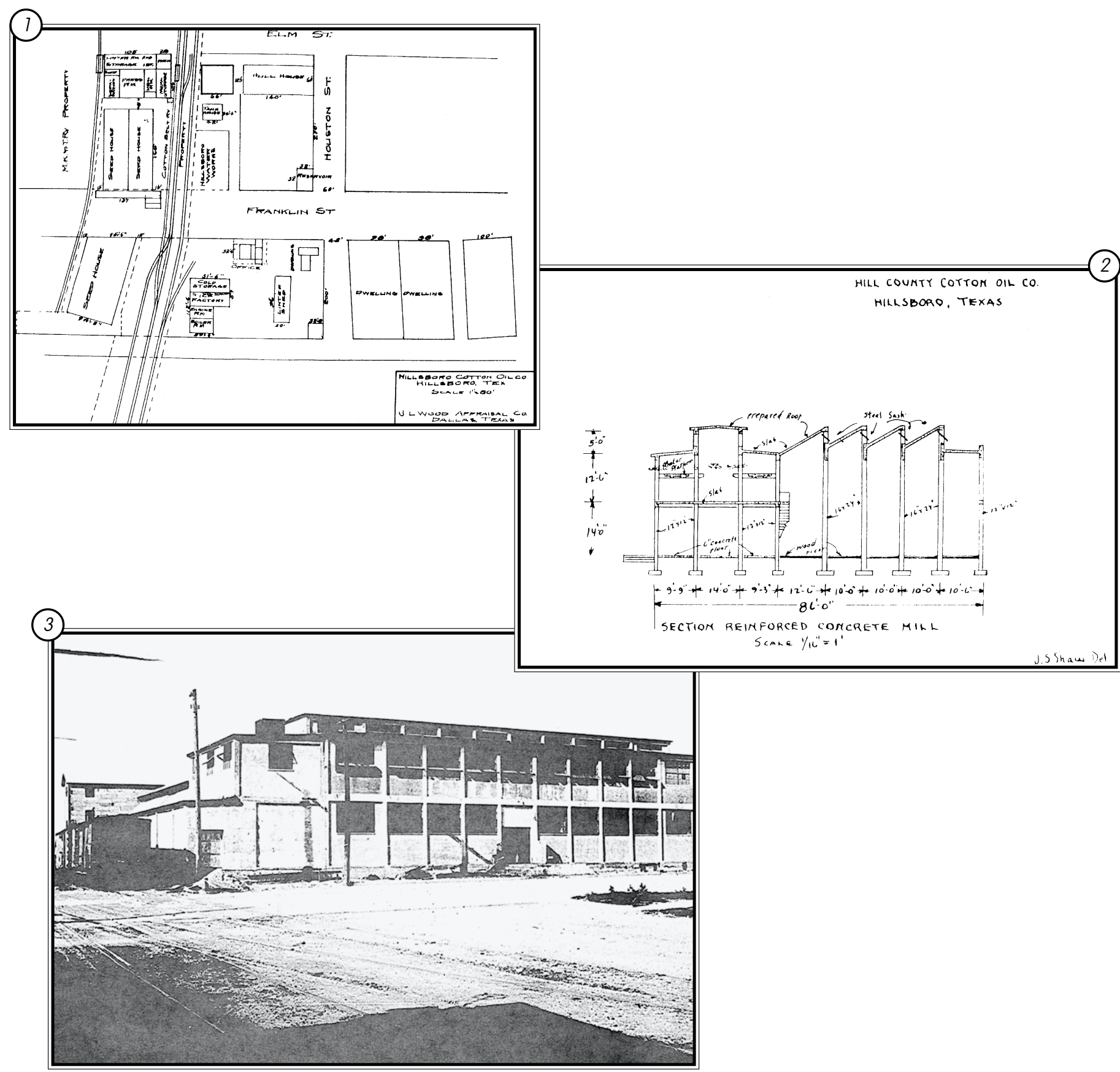

$1 \quad$ Founded in the mid-1890s, by 1931 the Hillsboro Cotton Oil Company was a very large country mill. It had all the constituent parts of a country cottonseed oil mill, with its mill building, seed houses, hull house, linter shed, and cottonseed oil tank house, spread over about four blocks along the Cotton Belt Railroad line. They also operated an ice factory, offered cold storage space, and owned three dwellings.

2 This profile of the Hillsboro Cotton Oil Company's reinforced concrete mill building shows two rooflines; the ca. 1918 tripartite gable roof series on the left predates the ca. 1925 sawtooth roof series on the right.

3 The main façade of the Hillsboro Cotton Oil Company has rhythmically articulated vertical bays. A railroad car sits on the tracks alongside the mill. 


\section{Cottonseed OIL Mills}
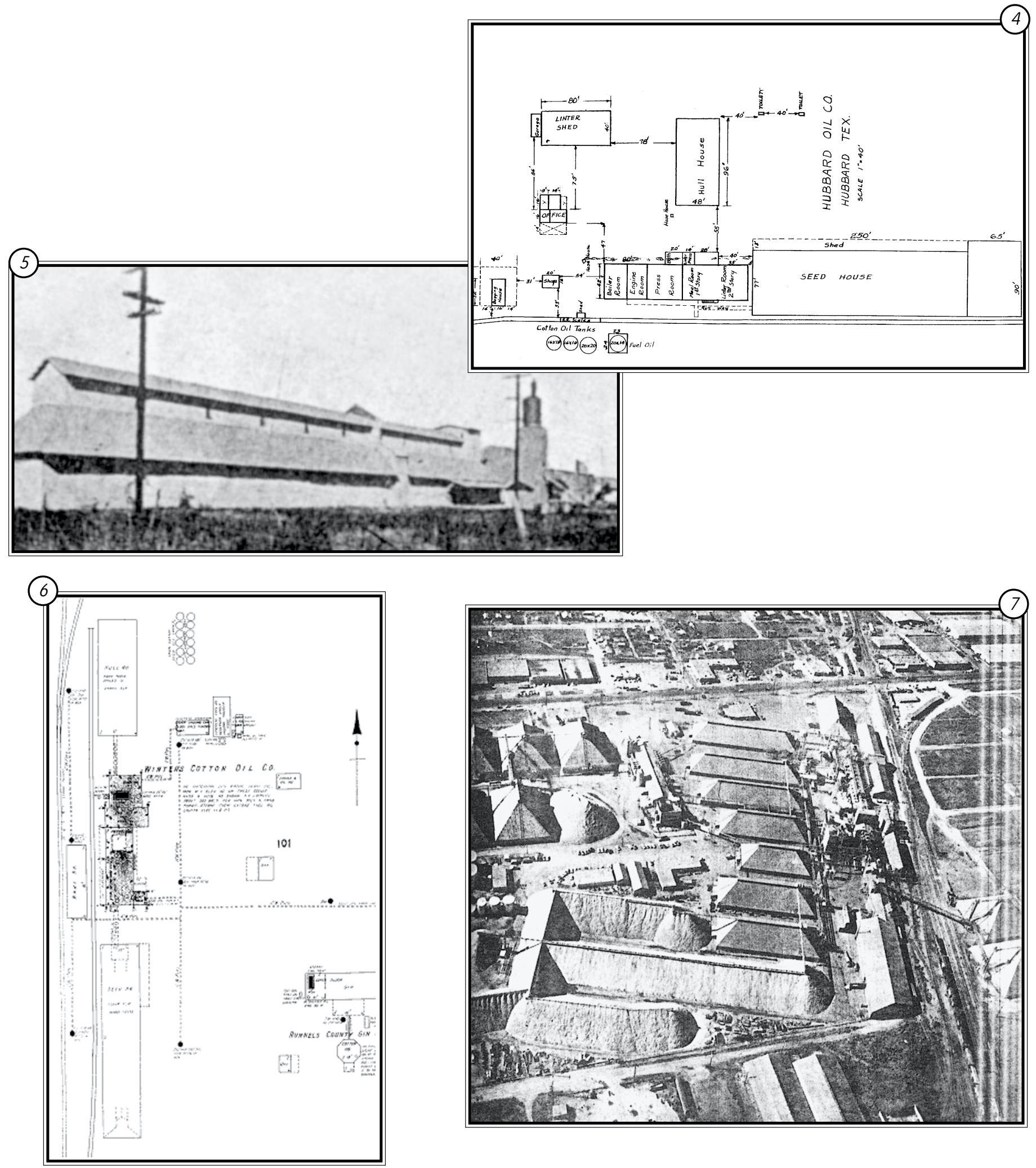

4 The Hubbard Oil Company was a smaller country mill on the Cotton Belt Railroad line that had a single large seed house, hull house, linter shed, and office in 1937.

5 The ca. 1917 Winters Oil Mill, a country mill, had a very large seed house.

6 In addition to the seed house, the Winters Oil Mill had a large warehouse, hull house, office, and cottonseed oil tanks.

7 Terminal mills, like the Plains Cooperative Oil Mill in Lubbock, employed seed houses for storage. After learning that openair storage would not harm seed, this mill, like others, stored more than 60,000 tons of cottonseed in huge piles on the ground. The processing complex at the mill is on the right, aligned with the railroad tracks. 


\section{Cotton Houses and Warehouses}

\section{Character-defining Features}

- Wood-frame or metal construction

- Wood or metal siding

- Wood or concrete foundation

- Wagon or truck bays on at least one façade

- Part of a complex, such as a gin plant, cottonseed oil mill, or cotton compress

\section{Principal Subtypes}

\section{Cotton Houses-}

- Freestanding building or appended to gin house

- Rectangular or octagonal plan with corresponding roof

- Suction device connects freestanding cotton house to gin house

- Associated with local gin plant or cottonseed oil mill

\section{Warehouses-}

- Freestanding building

- Rectangular plan

- Gable roof or other common variation, such as bowstring, multiple gables, two-bay gables, sawtooth, modified sawtooth, monitor, and crane

\section{Comments}

Cotton houses stored both unprocessed and baled cotton until the rush season was complete and demand might dictate higher prices. Cotton houses can be freestanding buildings or appended to a gin house. In either case, the cotton house may follow a rectangular plan with a gable roof or an octagonal plan with a corresponding roof. Cotton houses appended to the gin house usually date to the late nineteenth and early twentieth centuries. These early cotton houses were usually of frame construction with wood siding. Those built after about 1920 were usually metal. A suction device that discharged cotton into various bins connected freestanding cotton houses to the main gin house. Cotton houses are associated with local gin plants and cottonseed oil mills.

Warehouses were most often built for large facilities that received baled cotton and further compressed it so that it would take up minimal space in a railroad car or ship hold. Warehouses are usually freestanding rectangular buildings associated with cottonseed oil mills and cotton compresses and wholesalers. Warehouses built before about 1920 were usually of frame construction with wood siding. Those built after that date tended to be metal. 


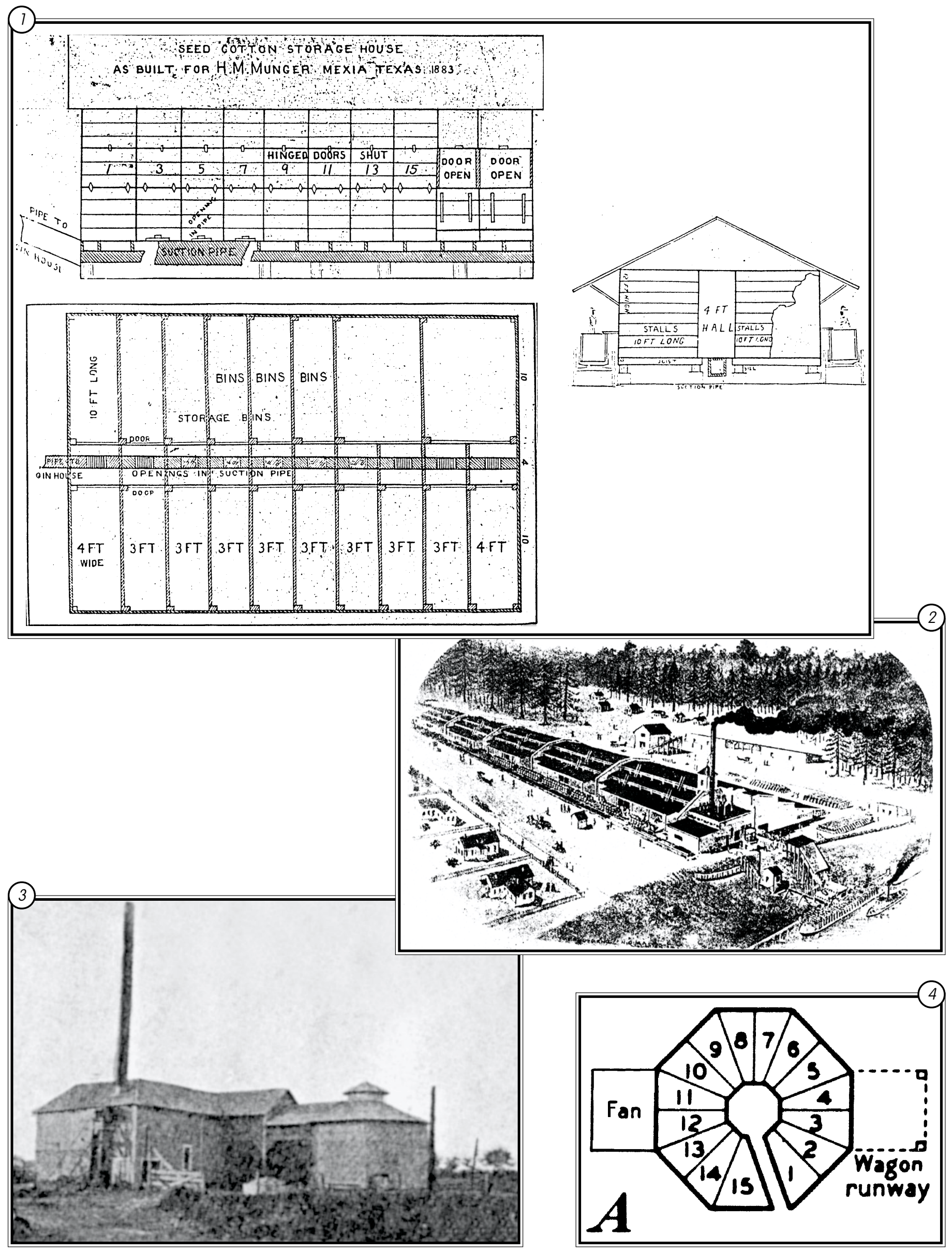



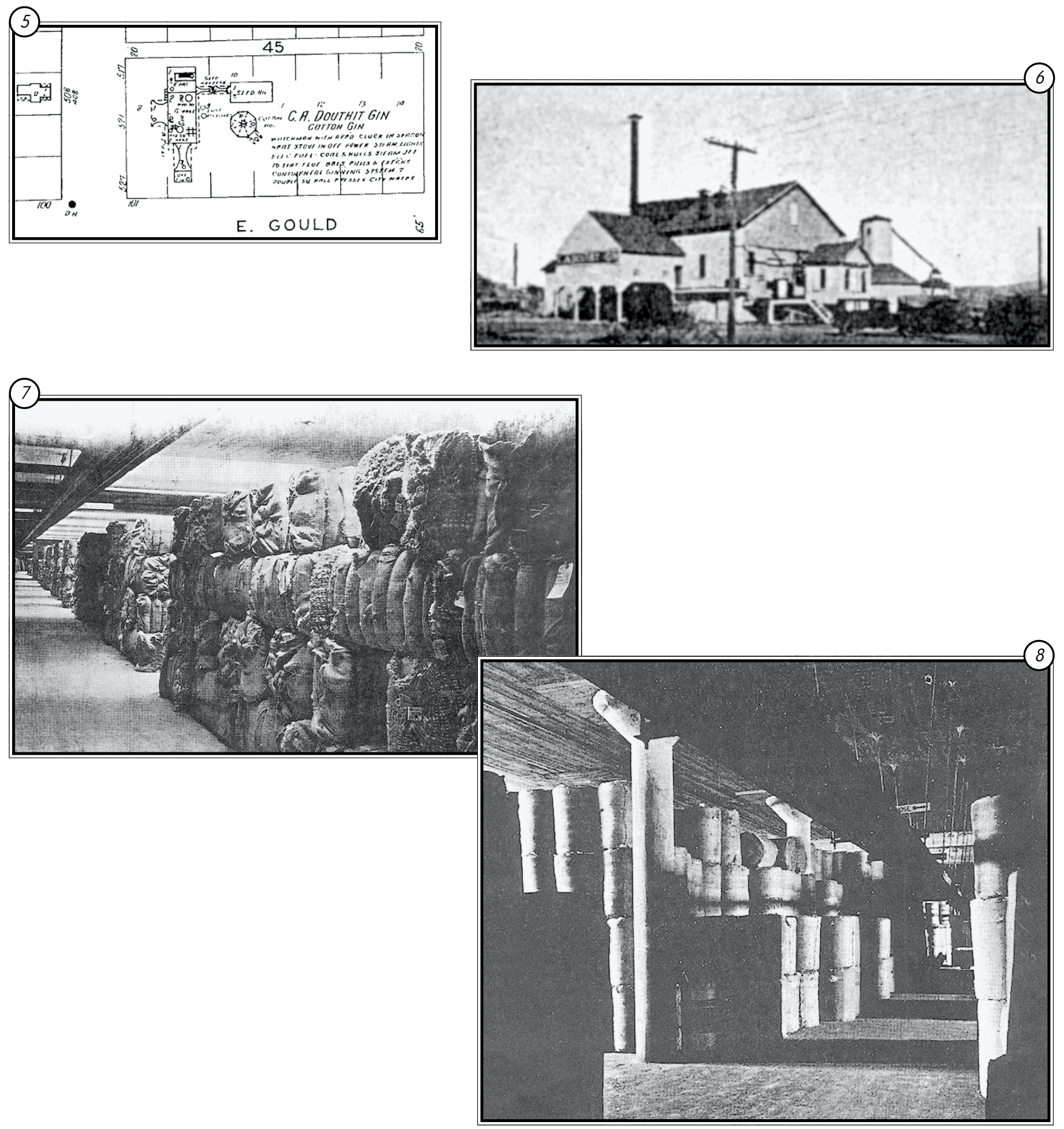

$1 \quad$ This 1889 drawing illustrates cotton storage in a Munger rectangular building that is freestanding.

2 A series of wood warehouses comprised much of the ca. 1893 Cleveland Cotton Compress for wholesale cotton.

3 Appended to the Planters Gin in Weinert is an octagonal cotton house of wood.

$4 \quad$ This layout shows the cotton storage system used in an octagonal building.

5 The C. A. Douthit Gin in Stamford had a freestanding octagonal cotton house.

6 The octagonal cotton house at the C. A. Douthit Gin appears in the far right background.

7 The interior of this warehouse stores high-density bales prior to compression into more-compact round bales.

8 Round bales are stored in this warehouse prior to shipping. 


\section{Seed Storage Facilities}

\section{Character-defining Features}

- Freestanding wood frame or metal building or structure

- Part of a complex, such as a gin plant or cottonseed oil mill

\section{Principal Subtypes}

\section{Seed Bins-}

- Elevated wood or metal structures

\section{Seed Houses-}

- Wood-frame or metal buildings or structures

- Usually long, rectangular plans

- Gable roof

- Small seed houses are elevated structures

- Large seed houses are buildings

\section{Comments}

Seed bins and houses store cottonseed after it is removed from cotton fibers. Farmers retrieve their seed for planting or feed, and the remainder is shipped to cottonseed oil mills.

Also known as seed boxes and hoppers, seed bins are found at most gin plants. These bins are elevated so that the cottonseed could be dumped from the bin into a client's waiting wagon, or into a truck for shipment to a cottonseed oil mill.

Seed houses vary considerably in size. Smaller seed houses are part of gin plants and, like seed bins, are elevated so that the seed could be transferred from storage to a wagon or truck. Large seed houses are at more substantial gin plants and cottonseed oil plants. Typically, large seed houses are buildings, and seed elevators or conveyors transported seed to and from storage.

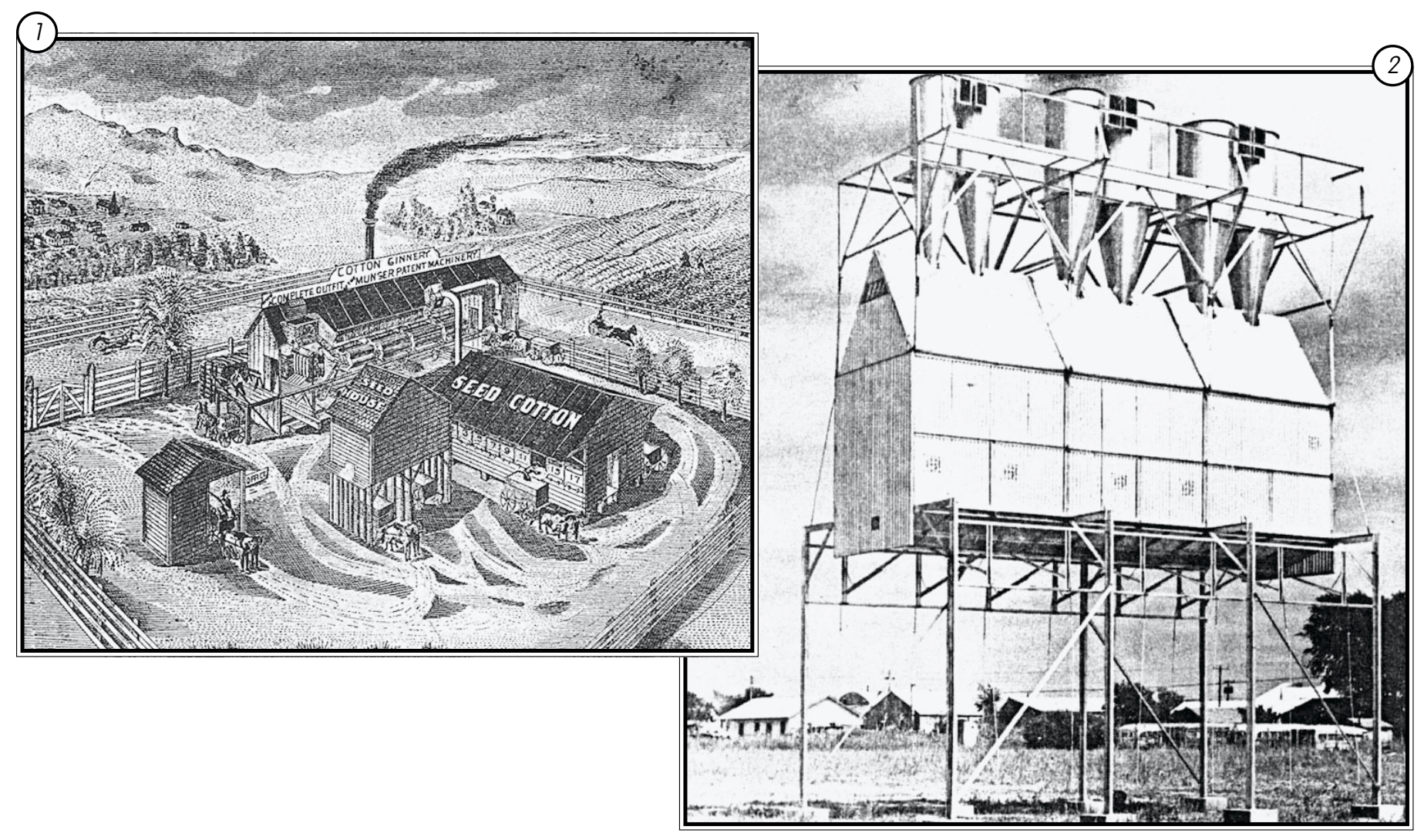




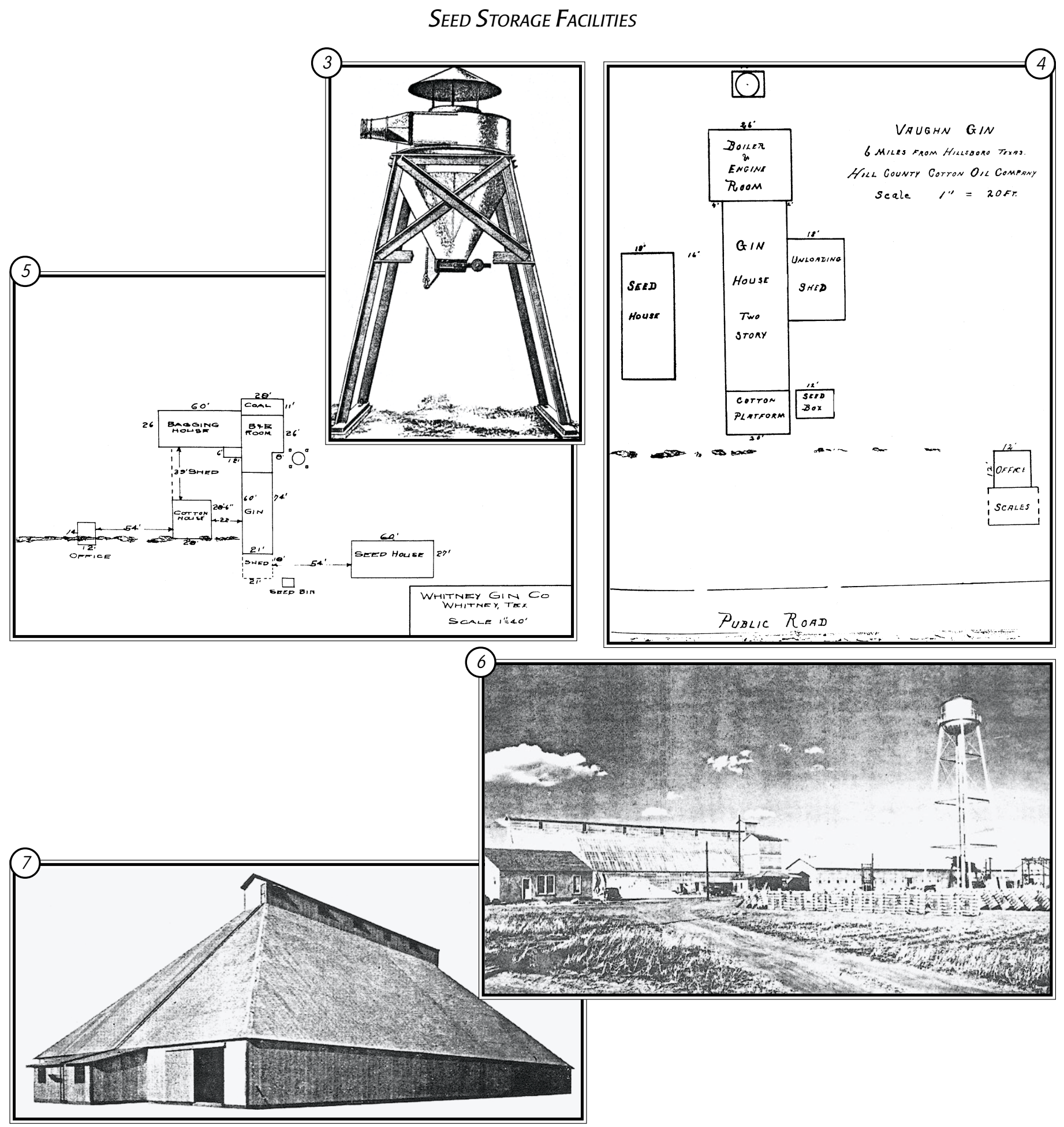

$1 \quad$ The 1889 seed house depicted at a gin complex in Mexia is elevated, and wagons are being loaded underneath.

2 An elevated seed bin has an overhead blow pipe or screw conveyor for delivery from the gin and dump doors to trucks beneath.

3 A small, metal cyclone seed bin allowed easy access for farmers who retrieved their cottonseed or purchased it from a gin plant. They drove wagons underneath the bin.

$4 \quad$ The Vaughn Gin near Hillsboro had a seed box from which farmers could easily access cottonseed. It also had a relatively large seed house where cottonseed was stored before shipment to a cottonseed oil mill.

$5 \quad$ The Whitney Gin Company in Whitney had a seed bin and a large seed house.

6 The Plains Cooperative Oil Mill operated this facility in 1937-1938. An office is to the far left, and the processing plant is at the far right. In the middle is a single large seed house.

$7 \quad$ The Austin Brothers Steel Company manufactured this seed house for the Lubbock Cotton Oil Company in 1951. Seed houses of this proportion were necessary at cottonseed oil mills. 


\section{Trash Collection Facilities}

\section{Character-defining Features}

- Freestanding brick or metal structure

- Part of a gin complex or cottonseed oil mill

\section{Principal Subtypes}

\section{Burr Burners-}

- Brick structure

- Conical or circular, occasionally rectangular

- Walls are typically 13 inches deep

- Brick may be with or without mortar

\section{Trash Hoppers-}

- Metal structure

- Cyclone hopper shaped like an inverted cone

\section{Comments}

At steam-operated cotton gin houses, burrs accumulated after ginning and were blown back into the boiler firebox for fuel, which did not require specialized structures. At electric- or oil-driven facilities this method of refuse management was not possible since there was no firebox. The refuse, instead, was often burned in open pits or temporary containers. Burr burners, also called hull burners or incinerators, made incineration less dangerous by confining the fire. Burrs and other trash were blown into the structure through a pipe, producing a circular motion and even distribution. These materials were then incinerated.

By the 1940s, dust and other wind-born foreign matter became increasingly problematic with the advent of mechanized cotton harvesting. Trash hoppers operate as middlemen between the gin and the burr burner. The main feature of these metal structures is the collection unit, which is often an inverted cone known as a cyclone hopper. Instead of blowing directly into the burr burner, trash enters the hopper first, where it is fanned through several straight blades that kill insects. The trash funnels downward and is blown into the burr burner. The incinerated ash can be marketed as fertilizer.
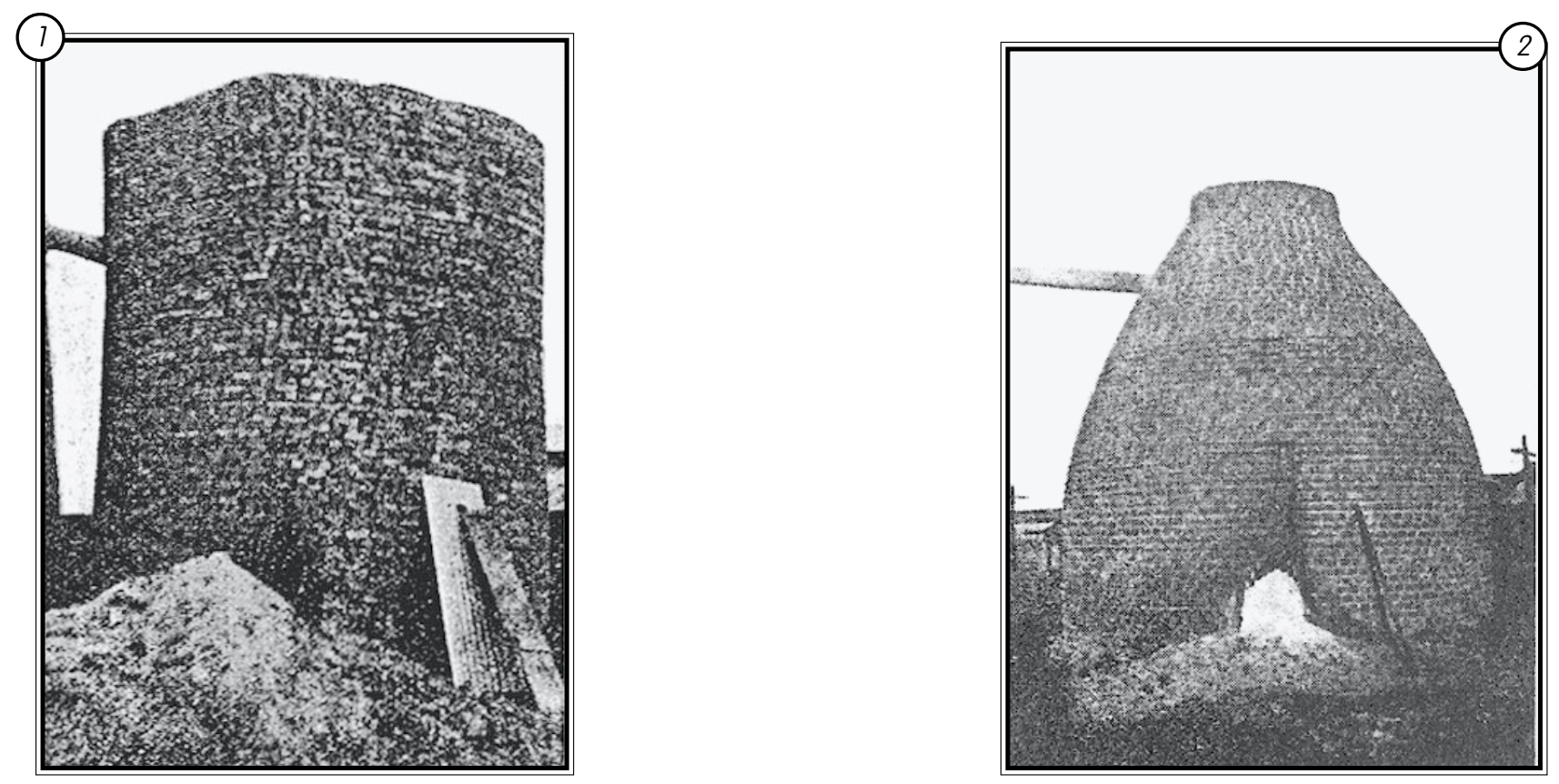


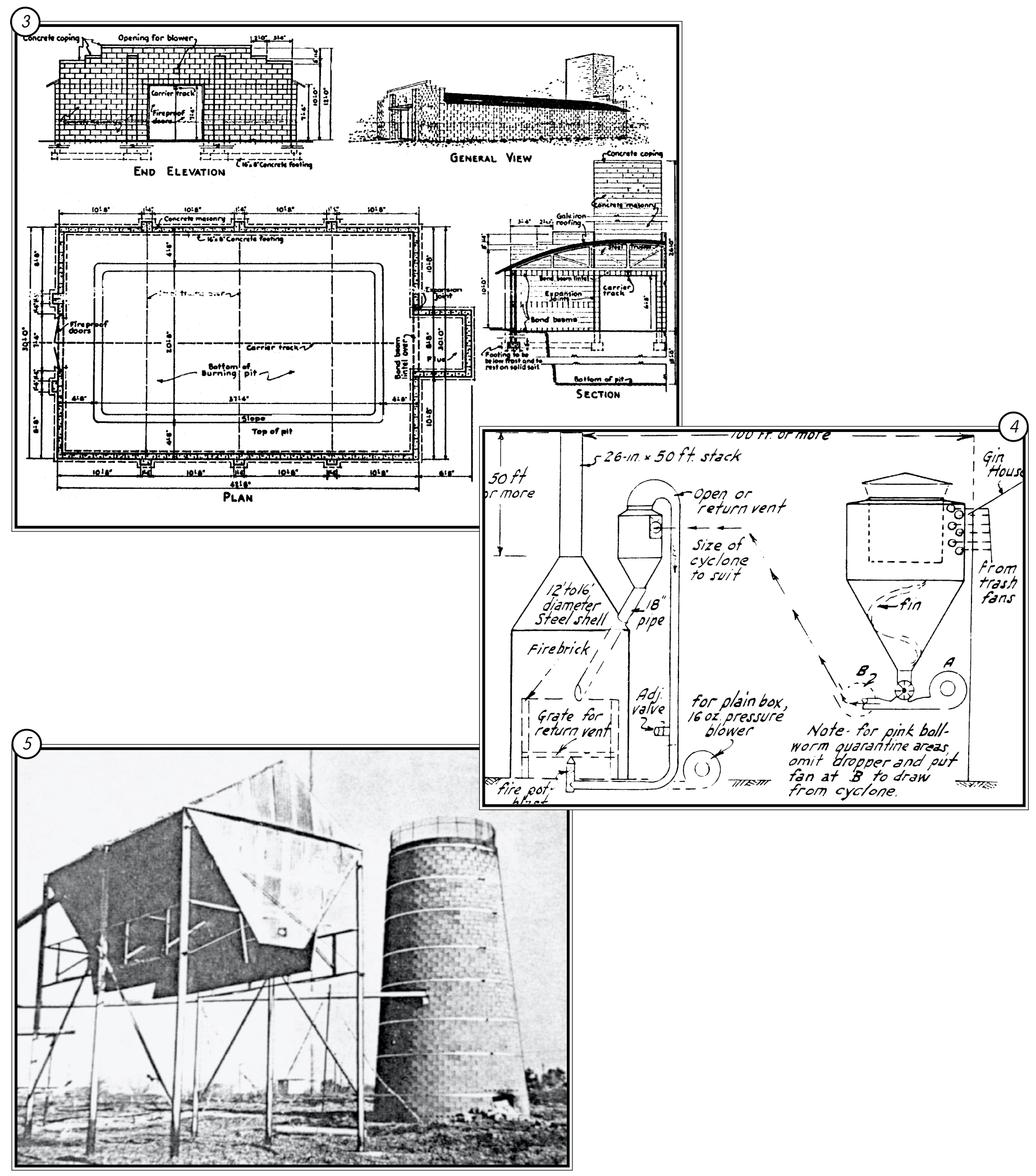

1 The construction of this ca. 1910s circular brick burr burner in Palmer had no mortar.

2 A ca. 1920s conical brick burr burner sealed with mortar in Ferris.

3 The Portland Cement Association recommended following this plan for constructing a ca. 1950 brick burr burner. The rectangular brick building could process huge amounts of gin trash.

$4 \quad$ This diagrams the movement of gin trash from gin house to burr burner for incineration.

5 A metal trash hopper, on the left, feeds a circular brick burr burner to the right. 



\section{Utilities ANd Services Property Types}

As the population grew from the nineteenth through the mid-twentieth centuries, a variety of utilities and services became increasingly important to Texans. Modern infrastructures, including electricity and water services, were first installed in large and small urban areas before being established in rural areas. An electric plant was built in Galveston in the early 1880s, and by 1900 many generating plants were operating in private hands. Usage statewide in-

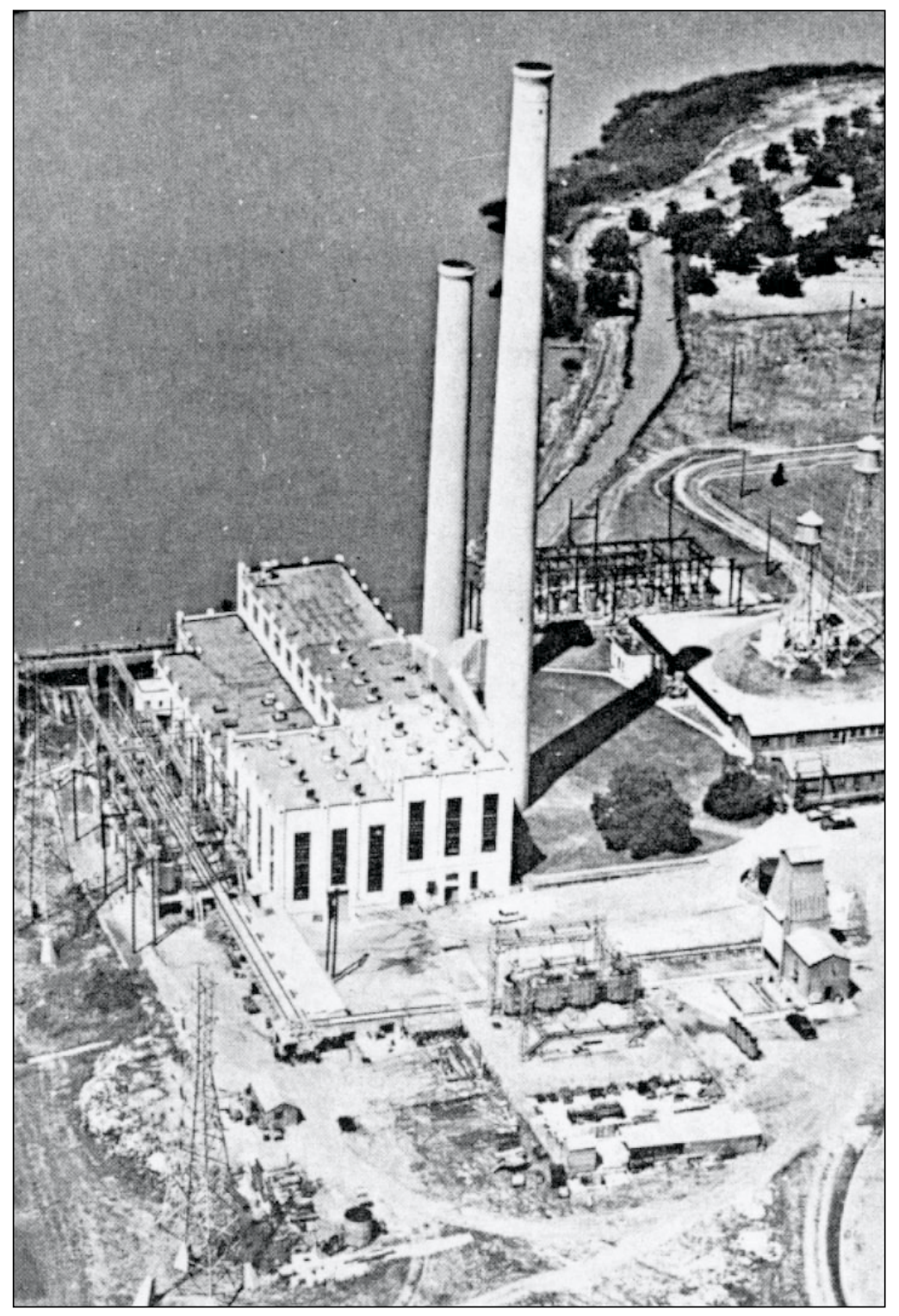
creased from 6 million kilowatt hours in 1920, to 1.2 billion kilowatt hours in 1925, to 6.78 billion kilowatt hours in 1945. This electricity was distributed almost exclusively to urban areas. The Rural Electrification Administration, begun in 1936, helped established 71 cooperatives and many private lines that, combined, served 164,000 rural homes by 1946. Internal combustion engines or steam provided the power for most electric generating plants.

Municipalities provided water services by way of waterworks that pumped water from nearby sources. After the turn of the century, water filtration became an effective way to decontaminate water and prevent widespread bacteria-born disease. Texas's first sanitary inspector served on the state health department in 1915. Two years later the state established the Bureau of Sanitary Engineers. It wasn't until the 1930s, however, when the federal Public Works Administration began providing financial assistance for wastewater projects, that sewage treatment plants became common in urban areas. The PWA devised design standards applied to waste-water plants and other facilities that often articulated Art Deco and Art Moderne stylistic influences.

Communications, in the form of telephone service, appeared first in Galveston in 1878. Just a year later the first telephone exchange opened there, and another was soon established in Houston. Early switchboards were rudimentary, and pole lines provided only party-line service; each telephone had its own battery with push buttons that sent a current to signal the operator. Telephone service reached many cities and towns in the 1880s. 
The first long distance line from Galveston to Houston was completed in 1883. The earliest operators were often boys and young men, but women operators soon became the norm. In 1899, the first switchboard with a common battery, instead of individual batteries, was installed in Dallas. Automated telephone service was available in Texas as early as 1903, and direct-dial service as early as 1921. Rapid expansion of telephone service, mostly party lines, took place during the first half of the twentieth century, both in urban and many rural areas. In fact, farm homes were more likely to have telephones than electricity until the mid-twentieth century. By 1946, Texas had 350 telephone companies with more than 1,000 exchanges and more than 1.1 million telephones.

The production of artificial ice became important in Texas during the Civil War, when the Union Army cut off the supply of naturally harvested ice from the North. A Carré absorption machine, using a mix of ammonia and water as a refrigerant, was in San Antonio by 1865 , and three additional companies in the city were operating ice plants 2 years later. Several Texans were instrumental in improving the refrigeration process, including Daniel Livingston Holden, who added steam coils to an absorption machine that required distilled water to make clear ice in about 1867. He experimented with petroleum ether and naphtha as refrigerants and patented his designs. In 1873, David Boyle established the first ammonia-compression plant in Jefferson. Charles A. Zilker of San Antonio established ice plants throughout the southern states in any city he could find financial backing and adequate water for compression. By the turn of the century, Texas had 77 ice plants-more than any other state. Innovations continued during the twentieth century, and liquid-vapor compression systems became popular, although ammonia remained in use. By the mid-twentieth century, home refrigerators were commonplace. In response, ice plants diversified and began to serve industrial and commercial clients.

Soda-water manufacturers in Texas existed by the mid-nineteenth century. By 1880, however, the state had only 11 bottling works. Just 10 years later, there were 42 soda-water manufacturers, 5 unspecified bottlers, and 7 breweries. When the Hutchinson bottle stopper (a wire loop protruding from the bottle neck and fastened to a rubber seall became more prevalent, new bottling works appeared in Texas. By 1900, there were 139 sodawater bottling works; 14 years later there were 262 bottling works. Most bottling works would cover a one- or two-county area. Some bottlers shipped by rail to nearby communities, but most delivered their goods by horsedrawn truck and, later, by motor truck. Franchises became popular in the mid-1910s, the most common being Coca-Cola, Nehi, and Dr. Pepper by the late 1920s. Pepsi-Cola and 7-Up broke into the Texas market in the 1930s. Rationing during World War II slowed the bottling industry and, even though sugar rationing continued through mid-1947, prices remained stable. Demand escalated in the postwar years. Bottlers found that new packaging techniques (e.g., cans and lightweight six-bottle cardboard cartons) and new ingredients (e.g., synthetic sweeteners) reduced their costs.

The property types associated with utilities and services and discussed in this field guide are electric utilities, water utilities, telephone utilities, ice service, and bottling works. 


\section{ELECTRIC UTILITIES}

\section{Character-defining Features}

- Masonry or metal building may be present

- Square or rectangular plan

- Flat or gable roof

> Transformers, wood poles, or steel towers

\section{Principal Subtypes}

\section{Generating Plants-}

- Complex of buildings and structures

- Large main building

- Interior accommodates generating equipment, boilers, air compressors, air conditioning equipment, control boards, and switching equipment

> Transformers

- Water towers

- Warehouses or sheds

- Oil- and coal-powered plants near railroad line

- Water-powered plants adjacent to water source and associated dam

\section{Substations-}

- Series of transformers of wood, metal, or both

- Fencing surrounding transformers

- Substantial overhead lighting

- Small one-story wood-frame or metal building may be present

\section{Transmission Lines-}

- Wood or metal line poles

\section{Company Office Buildings-}

> One- or two-part commerical-block form

- In downtown area

- Interior space for reception, engineering, accounting, purchasing, and other business activities

- Sidelines such as ice stations

\section{Comments}

Plants generate high-voltage electricity and send it to substations via high-voltage transmission lines. Oil, coal, or water can provide power for an electric generating plant. Those running on oil or coal must be near a railroad line; those running on water must be adjacent to a water source. A large main building accommodates generating equipment, boilers, air compressors, air conditioning equipment, control boards, and switching equipment. These buildings often display modest stylistic influences that reflect contemporaneous design trends. Early plants may evoke classically inspired detailing, such as symmetrical fenestration patterns, emphasized cornice and frieze lines, and prominent central entryways. Those constructed in the 1920s and 1930s may exhibit Art Deco or Art Moderne attributes. Plants constructed in the mid-twentieth century likely employ International Style design principles. Outside the main building are transformers, water towers, and necessary warehouses or sheds for repairing and storing equipment and tools. After World War II electric plants began to use generating units that did not need protection from the elements.

Substations reduce the voltage level as it is distributed from generating plants to customers. They are typically composed of a series of transformers made of wood or metal or both. For safety reasons, fencing surrounds substations and they have substantial overhead lighting. Occasionally, a small, one-story, wood-frame or metal building provides protection for equipment. 


\section{ELECTRIC UTILITIES}

Electricity is distributed from both generating plants and substations via transmission lines. Early transmission line poles were made of wood; later transmission poles are steel towers. High-voltage transmission lines dispatch electricity from generating plants to substations. Low-voltage transmission lines transport electricity from substations to customers.

Office buildings provide space for managing company business in a safe and professional environment. Offices for electric companies are usually removed from operating plants to keep employees and customers alike safe, as well as to protect equipment. Company buildings house reception, engineering, accounting, purchasing, and other business activities. In smaller towns they might house both the electric company business and operate sidelines, such as ice stations. These buildings are usually one- or two-part commercial-block forms. Since office buildings are the public face of the business, they are most likely to exhibit architectural stylistic influences that suggest the company's sense of modern innovation. Thus, these office buildings often reflect contemporaneous in architectural design.
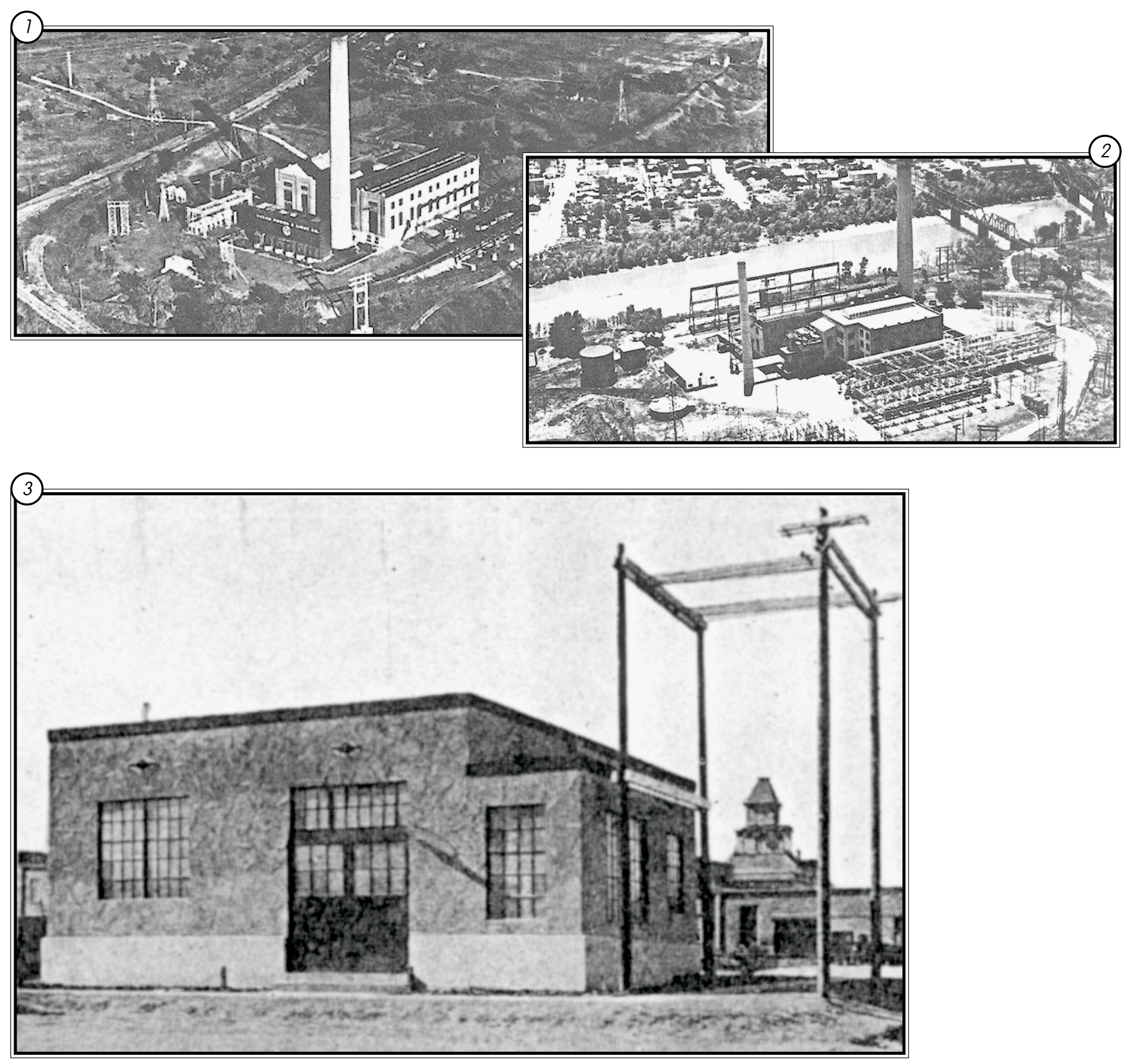


\section{ELECTRIC UTILITIES}
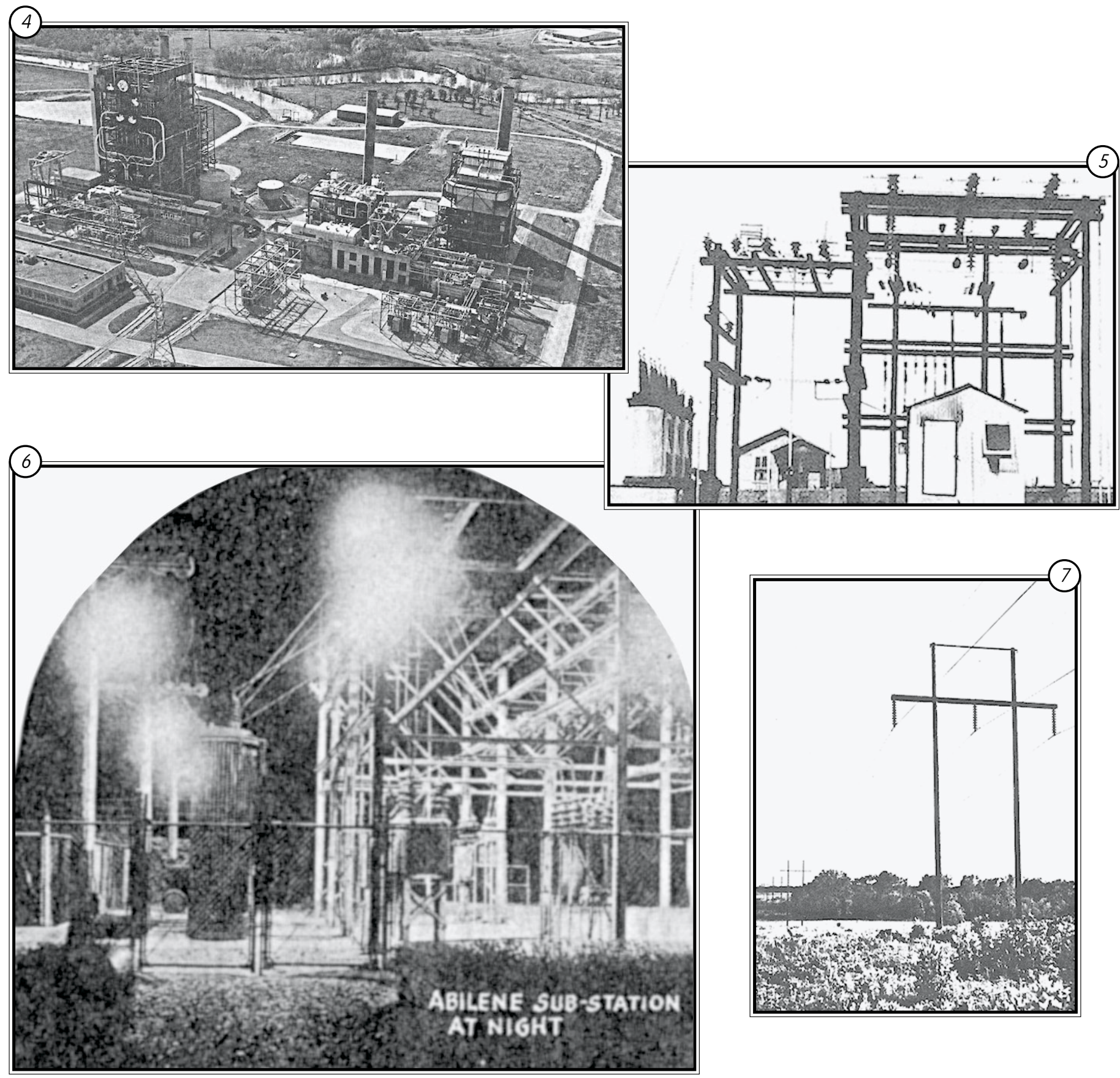

$1 \quad$ The 1909 generating plant of the Texas Power \& Light Company in Waco was a complex with a brick main building and transformers on the Brazos River. This plant was destroyed by a 1913 storm.

2 By 1949, Texas Power \& Light Company in Waco had reconfigured the plant to meet modern standards. Transformers comprised most of the complex , and the main brick building that housed equipment was substantially smaller than the earlier plant it replaced.

3 The ca. 1920 Paducah generating plant, first owned by the city, had become the property of the West Texas Utilities Company by 1926. It is representative of a small town facility.

$4 \quad$ The Texas Electric Service Company generating plant in Handley was the first to use outdoor generating units (center) in 1948. These had a capacity of 45,000 kilowatts. On either side are units of 80,000 and 400,000 kilowatts installed in 1950 and 1963.

5 A small metal building was on the site of the ca. 1920s Texas Power \& Light Company substation at Jacksboro.

6 Safety fencing and lighting are visible at the ca. 1920s West Texas Utilities Company substation in Abilene at night.

7 These high-voltage transmission lines were run on wood H-frame poles by the Texas Power \& Light Company in the early 1920 s. 

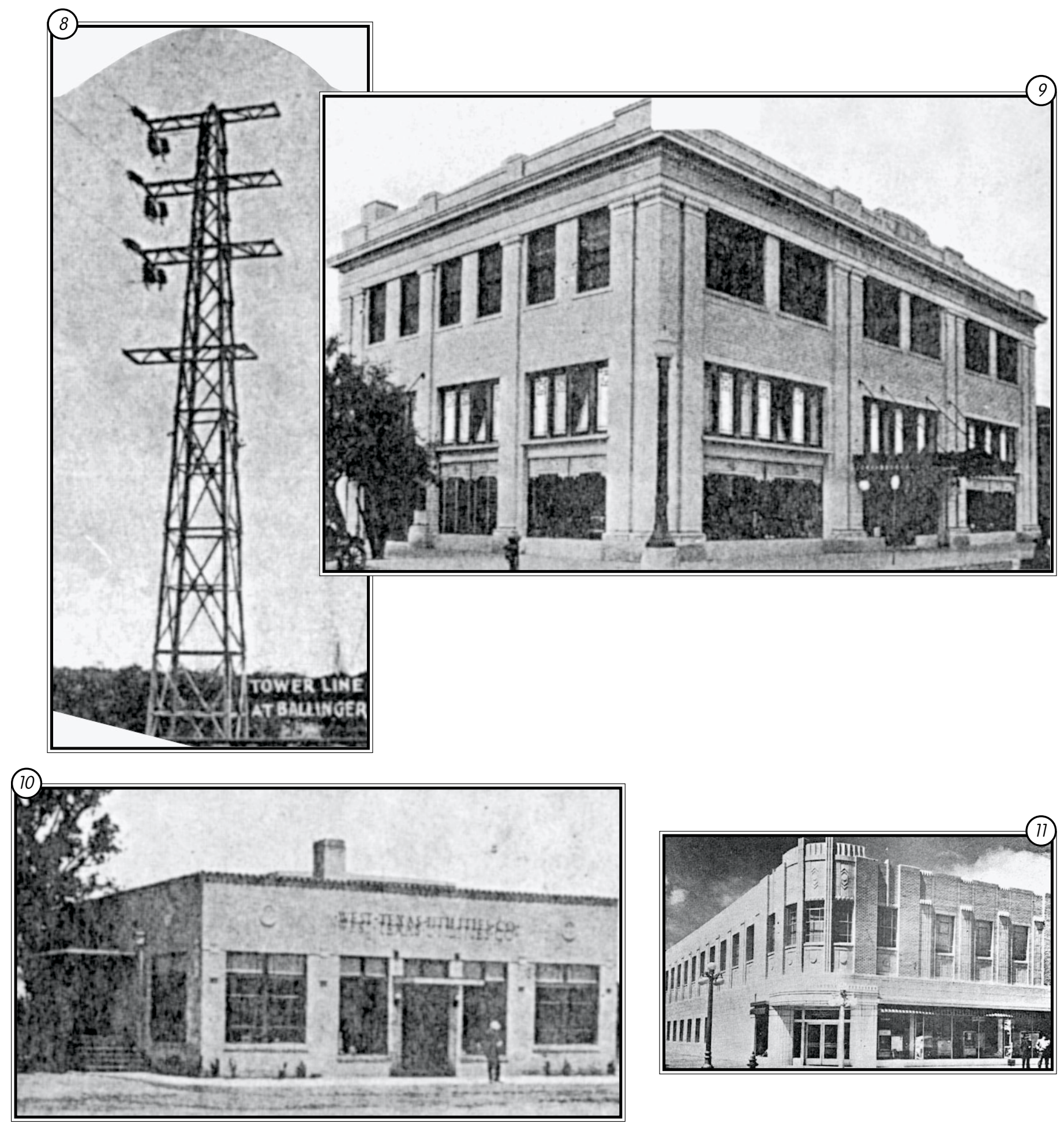

8 This ca. 1920s West Texas Utilities Company high-voltage transmission line is on a steel tower near Ballinger.

9 Classical Revival design characteristics defined the office building of the West Texas Utilities Company in Abilene. A ca. 1925 two-part commercial-block, brick building, its symmetrical fenestration patterns, emphasis of cornice and frieze lines, and prominent central entryway are all classically inspired.

10 Smaller towns, like Menard, also had a separate office building for the electric company. This ca. 1926 one-part commercial-block West Texas Utilities Company office building utilized modest Spanish Colonial Revival architectural influences with its smooth exterior surface, tile roof, and stylized emblems and light fixtures.

11 The Amarillo office of the Southwestern Public Service Company was downtown at the corner of Fifth and Polk Streets. It is a ca. 1928 two-part commercial-block, brick building with Art Moderne detailing as exhibited in the stylized cast concrete geometric reliefs that decorate the building. 


\section{Water Utilities}

\section{Character-defining Features}

- Main building usually of masonry construction

- Pump stations

- Holding reservoirs

> Treatment tanks

\section{Principal Subtypes}

\section{Waterworks and Filtration Plants-}

- Booster pumps

- Settling basin, either natural or man-made

> Piping system

- Storage tanks

- Filtration equipment

- Usually removed from city center, but may be in urban area

\section{Sewage Treatment Plants-}

> Pipe-collecting system

> Disposal unit

- Pumps and pump house

- Imhoff settling tanks

> Aerator tanks

Digester

- Sludge-drying bed

- On several acres removed from city center

\section{Comments}

Waterworks and filtration plants move and process water for human consumption and use. Waterworks use a pumping system or a series of pumps to move water from its source to a central location for distribution. Filtration plants treat the water prior to distribution. Depending on the size of the population being served, waterworks and filtration plants require anywhere from a small parcel to several acres of land. Some facilities are removed from the city center, while others are in urban areas. Electric-powered pump stations draw water from its source, such as a lake, through an intake and water pumping station. Booster pumps continue to move the water through pipes to a settling basin, which can be a natural valley or a man-made concrete reservoir. In the basin impurities break down and sediments settle. After settling, a waterworks delivers the water to storage tanks, from which the water is dispersed to consumers. Filtration plants became increasingly common by the mid-twentieth century and provided purification of water with chemicals, mixing, settling, and filtering, before distribution to consumers.

Until the twentieth century, most wastewater in Texas was disposed of in privies, yards, alleys, cesspools, or reservoirs. By the 1920s, many urban areas had installed sewage treatment plants to handle post-consumer waste. Depending on the size of the population, sewage treatment plants require anywhere from a small parcel to several acres of land that is removed from the city center. Sewage is collected through pipes and coarse material is separated at a treatment plant. The remaining sewage passes through a tank system, again separating materials. Liquids are processed and released to percolate into the soil or directly into waterways. Solids settle in the bottom portion of an Imhoff tank. The organic material dissipates and the inorganic material, or sludge, is pumped to drying beds where it dehydrates for several weeks and is then moved by truck and dumped on available ground. A typical activated sludge treatment plant would include a pipe 


\section{WATER UTILITIES}

collecting system and a disposal unit with Imhoff settling tanks, aerator tanks, digester, sludge-drying bed, and pump house.

Buildings associated with water services often reflect popular contemporaneous architectural styles. Buildings constructed in the nineteenth century might exhibit late Victorian-era design. Richardsonian Romanesque detailing is common, which often incorporates rough-faced stone into an asymmetrical plan. Early twentieth century buildings might be more reflective of classically inspired design with symmetrical fenestration patterns, emphasized cornice and frieze lines, and prominent central entryways. Buildings and structures constructed in the 1920s and 1930s can invoke modernistic detailing that might express Art Deco stylistic influences. In the 1930s, the Public Works Administration began providing financial assistance for water and wastewater projects. Construction funded through federal sources was likely to include designs that applied Art Moderne or International Style form and detail.
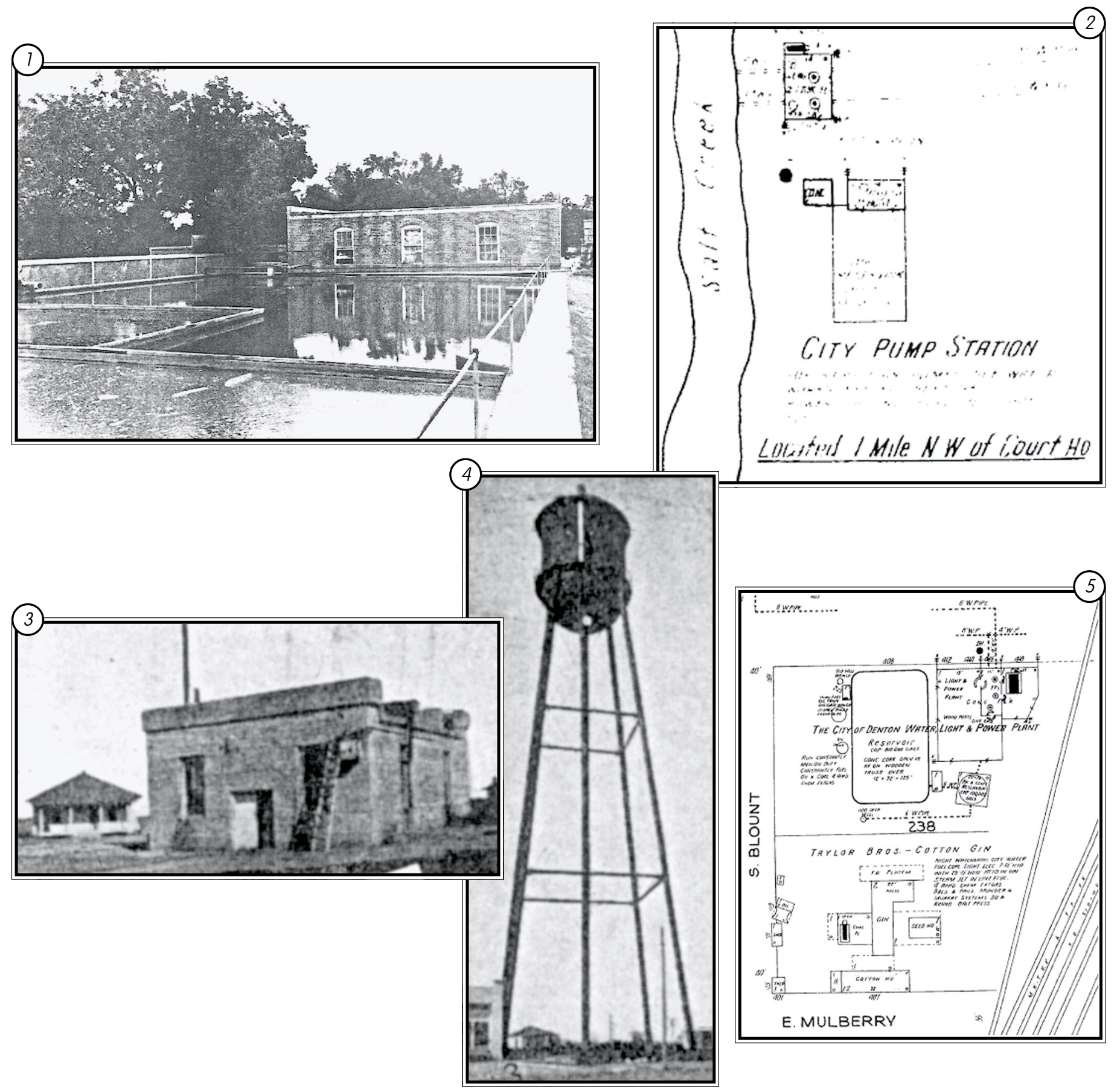


\section{WATER UTILITIES}
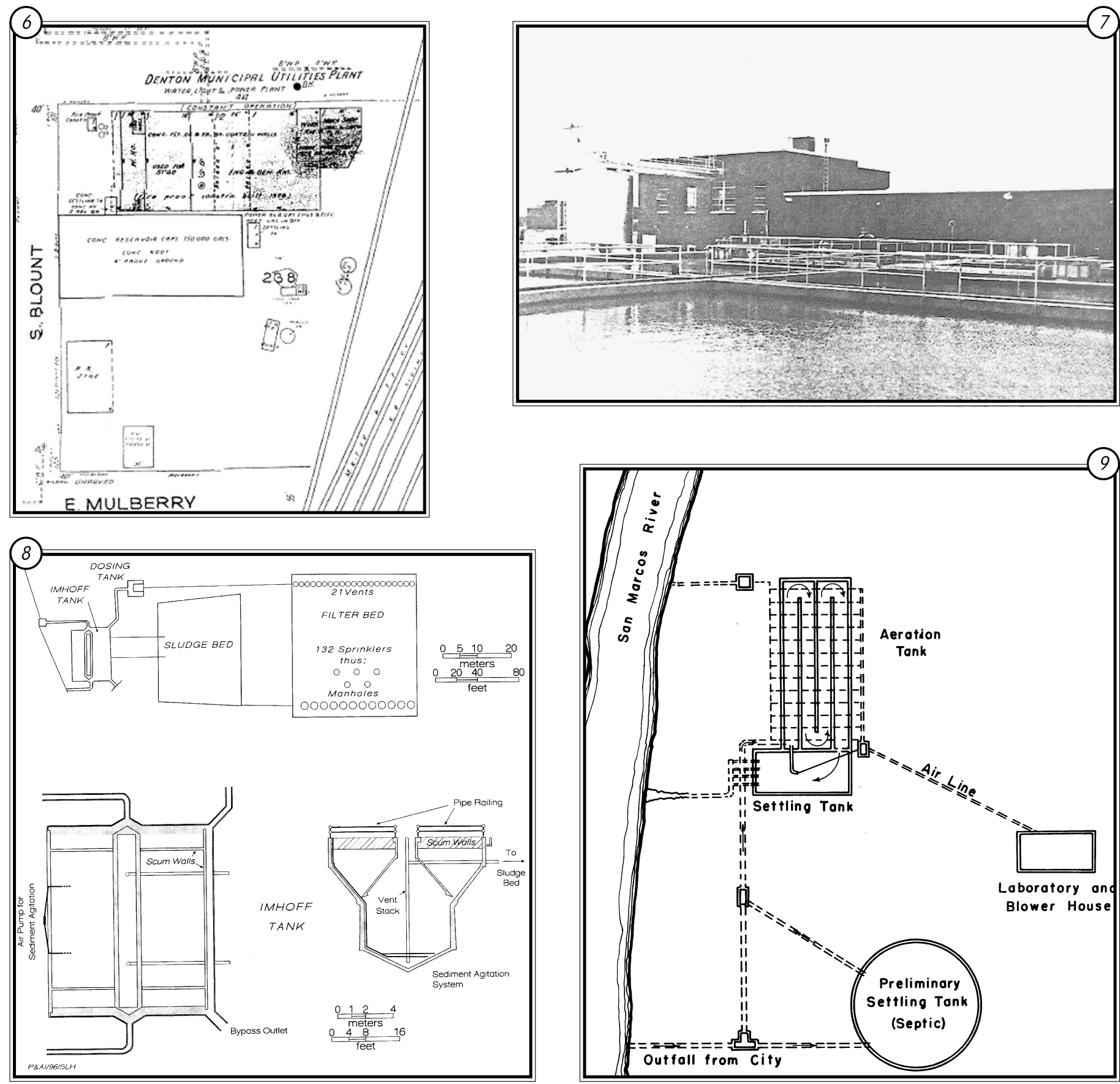

1 The brick 1909 waterworks in Graham is a good example of Classical Revival design with its emphasis of cornice and frieze lines and arched pediments over symmetrically placed, double-hung, wood windows. Classical inspiration is carried out in the settling basin's evenly placed vertical divisions.

2 A footprint of the waterworks in Graham shows Salt Creek as its water source.

3 The ca. 1927 Stamford pump station shows modest classically inspired detailing.

4 A ca. 1920s water tower in Rule towers above the community.

5 In 1926, Denton's water, light, and power plant took up half a city block and included a reservoir with a capacity of 610,000 gallons.

6 By 1949, the Denton plant took up the entire block and had a capacity of 750,000 gallons.

7 International Style design incorporated the latest innovations in water filtration at the new filtration plant built in Denton in 1956.

8 This plan of a facility at Camp Bullis and cross section of an Imhoff tank illustrates the sewage treatment process.

9 The 1916 San Marcos Activated Sludge Sewage Treatment Plant was the first successful plant of its type to serve an entire city. Substantial modifications occurred in later years, but this plan shows the facility's earliest layout. 

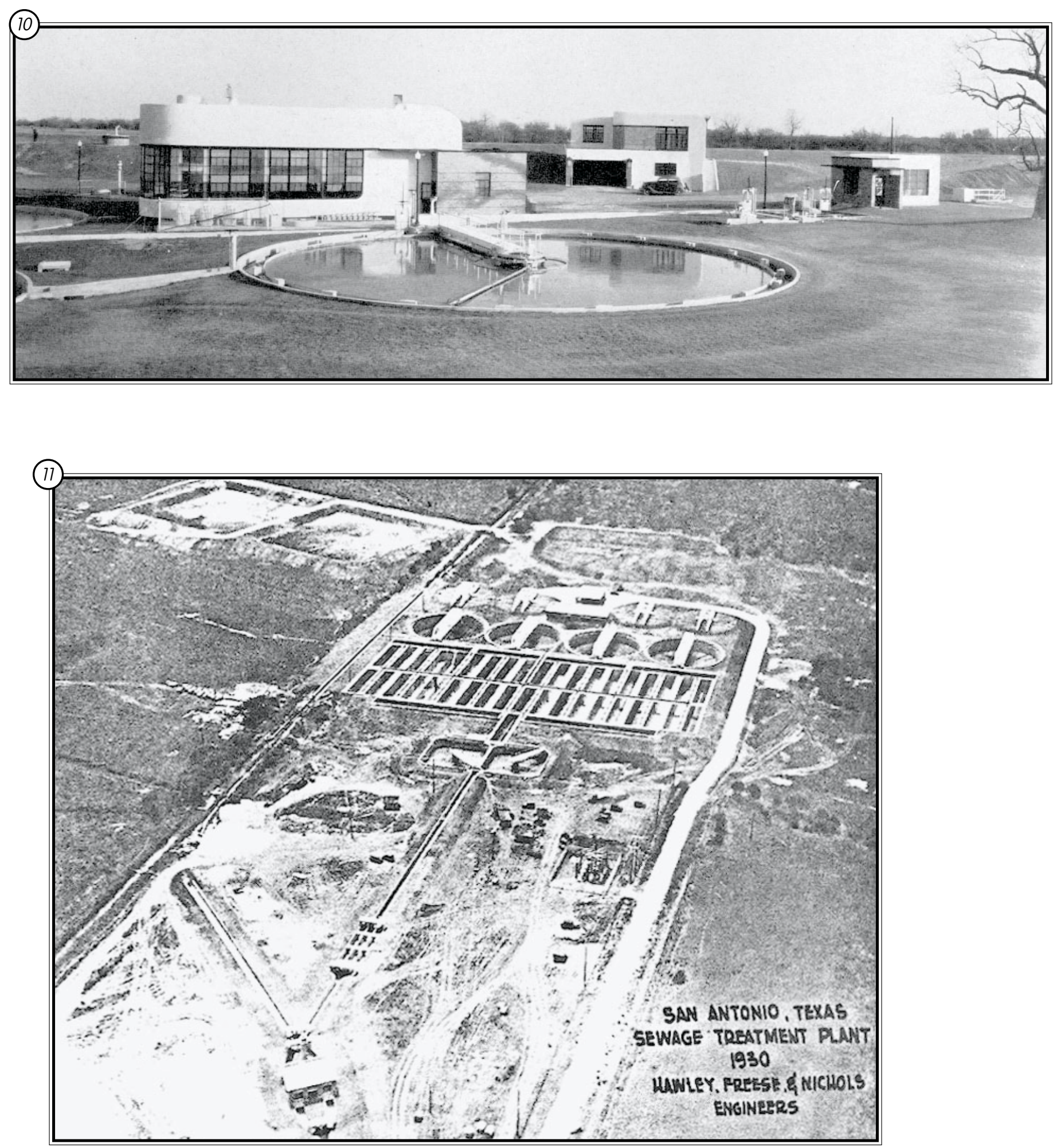

10 Hawley, Freese \& Nichols designed this activated sludge sewage disposal plant in 1934 for Austin. The Public Works Administration financed the plant, which was placed in operation in 1937. It could handle 6 million gallons a day.

11 San Antonio was a boomtown in the 1920s, and its population growth necessitated a sewage treatment plant that could handle 30 million gallons a day. The 1930 Rilling Road plant, 6 miles south of the city, covered an area just under 5 acres in the same location as the city's initial 1897 sewage farm. Designed by Hawley, Freese \& Nichols in 1928, it was the city's first sewage treatment plant. 


\section{Telephone Utilities}

\section{Character-defining Features}

> Wood-frame or brick building

- Hipped or gable roof

- Evenly spaced creosoted wood telephone poles with wiring wrapped around insulators

\section{Principal Subtypes}

\section{Exchange Offices-}

- Small exchange office with switchboard might be in a dwelling or store

- Medium-sized exchange office in one-part commercial-block wood or brick building

- Large exchange office in one- or two-part commercial-block brick building

\section{Pole Lines-}

- Creosoted wood telephone poles with crossbar

- Typically eight insulators, four on either side of crossbar

- Telephone wire wrapped around insulators

\section{Comments}

Private companies developed telephone systems with exchange offices and pole lines in the late nineteenth and early twentieth centuries. All but the most rural places had telephone service by the late 1920s. Telephone users subscribed to service that connected through an exchange office, where calls were hooked up on a switchboard. Local telephone companies could contract with larger firms for access to long-distance service. In the 1950s, automatic dial systems were introduced to most communities and telephone exchanges became obsolete.

Exchange offices are of various sizes. Small towns necessitated only small exchanges. Likewise, larger towns and cities required ample facilities. Regardless of size, a single community might have more than one exchange office of differing sizes, since competing telephone companies had ownership of certain pole lines. A small telephone exchange office in a crossroads community could house a single operator in a dwelling or small dry goods store with a switchboard exchange. Small exchanges, as well as larger offices received customers for bill payment. In a medium-sized town, a telephone exchange office with a dedicated building might have six or more operators serving. This might include two toll operators, a rural operator, and three local operators. The building was often a one-part commercial-block of wood-frame or brick construction, but it could also take the form of a one-story dwelling. In either case these buildings usually exhibited contemporaneous stylistic influences. In major cities, the telephone exchange was a much larger operation and might be a two-part commericalblock brick building several stories in height.

In the early years, telephone wiring commonly was strung from rooftops and trees to establish telephone service. The wiring itself might be as rudimentary as barbed wire and barbed-wire fence could facilitate telephone use. Creosoted wood telephone poles became the preferred apparatus from which to suspend telephone wire. Typically, eight insulators, four on either side, would traverse a crossbar and the telephone wire would be wrapped around the insulators and strung along to the next pole. 

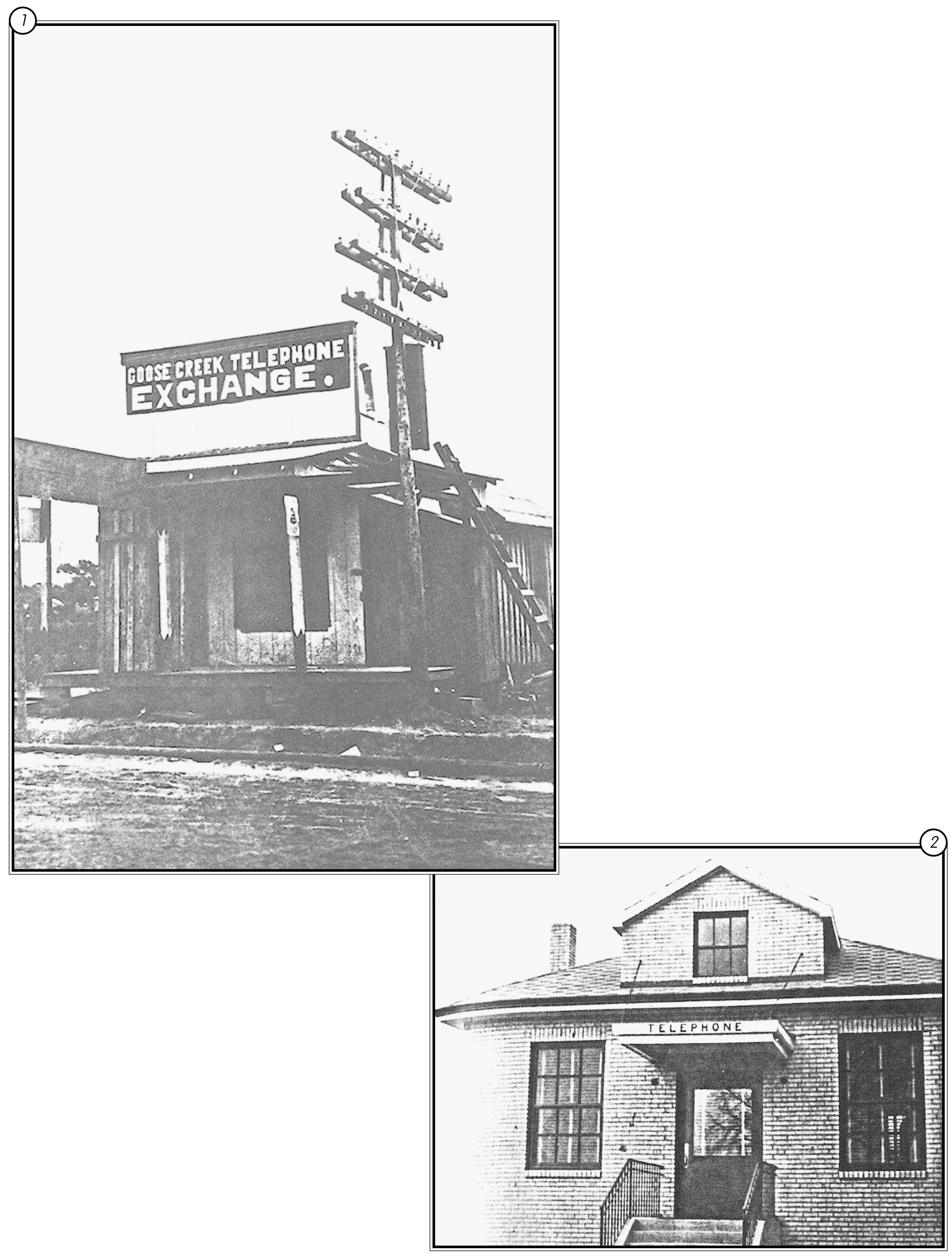


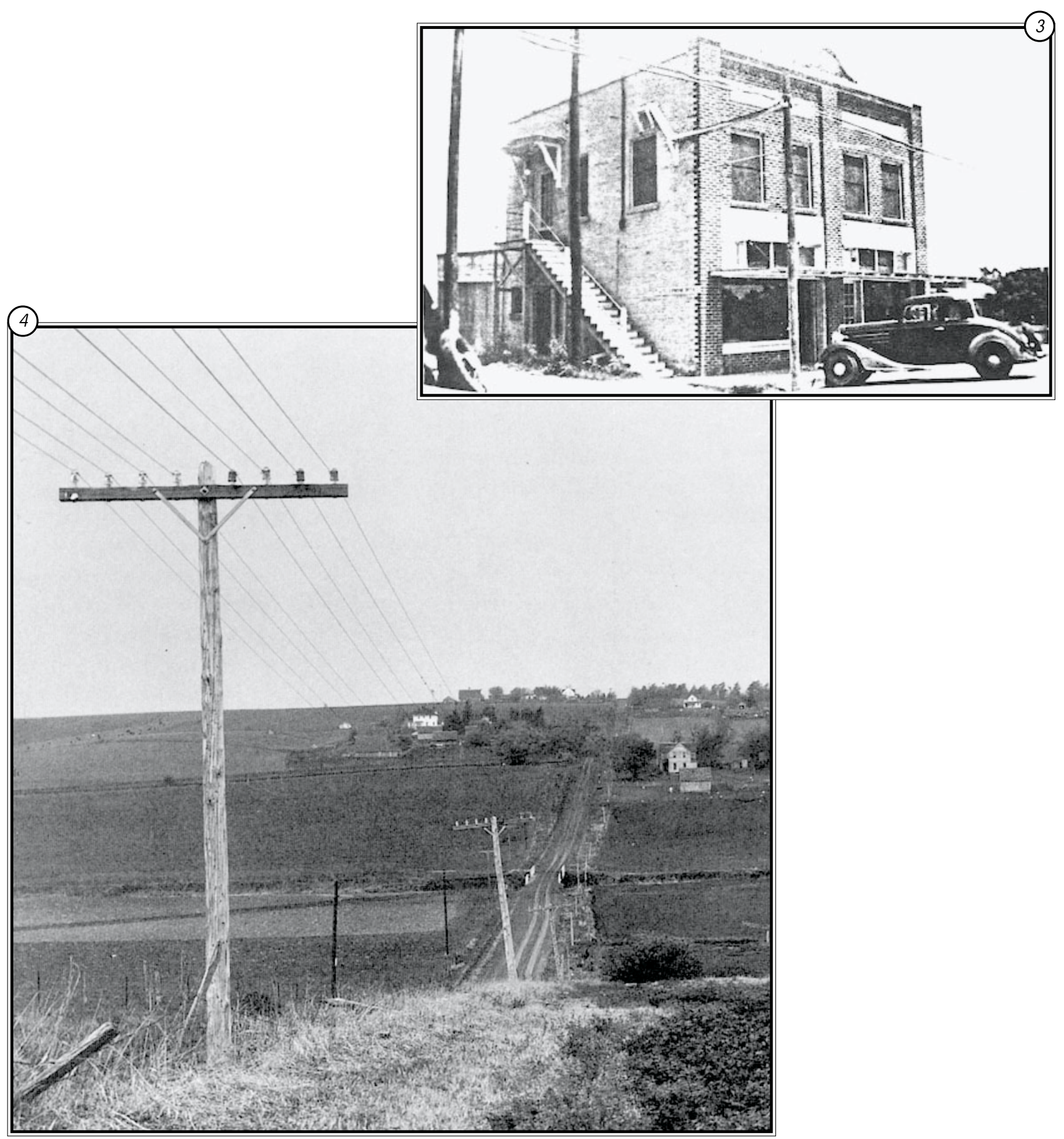

1 The ca. 1920 one-part commercial-block Goose Creek telephone exchange office had a ladder perched against the building for easy access to the pole line.

2 The Texas Telephone Company owned the brick Garland telephone exchange office in 1941. The building resembled a bungalow form with classically inspired detailing.

3 From the telephone pole line in front of the building, the cable trough enters the brick Weslaco telephone exchange office above a second-level window of the side elevation in 1951. This two-part commercial-block building features modest Classical Revival influences.

$4 \quad$ Telephone pole lines traversed the countryside. 


\section{ICE Service}

\section{Character-defining Features}

- Masonry building

- Rectangular or L-shaped

- Usually one-story, but can be two-story

- Usually flat roof, but other forms occur

- Windows indicate interior office space

- Platforms with shed roofs on rear and side elevations

- Sidelines such as cold storage, refrigerator sales, and convenience stores

\section{Principal Subtypes}

\section{Plants-}

- Large masonry building

- One or more interior storage vaults

- Compressors

- Freezing and ammonia tanks

- Adjacent water source or direct lines from waterworks

- Powered by electricity

\section{Service Stations-}

- Small masonry building

- One or two storage vaults

- No processing equipment

- Drive-up bay

\section{Comments}

Until the late nineteenth century, ice was transported via railroad or shipped to Texas from northern states. The cost of transport, in addition to loss from melting, made ice very expensive. Ice-making equipment and the evolution of cold storage made ice readily available to consumers. By 1909, Texas had 182 ice plants. Ice was delivered door-to-door or could be purchased wholesale or retail from the platform of local ice companies. Not surprisingly, prices were higher in the summer than in the winter.

At a minimum, ice plants processed, stored, and sold ice. Each plant had one or more large vaults for storage, compressors, and freezing and ammonia tanks for making ice. Office and sales spaces contained windows, the remaining areas were without windows to keep the facility cool and dark. Ice plants required adjacent water sources or direct lines from waterworks and were usually powered by electricity, thus ice plants could be independently owned, but many were affiliated with local electric companies. Ice plants often offered sidelines of their own, like cold storage, refrigerator sales, or convenience stores, to boost profits. Architectural detailing typically reflected popular contemporaneous design trends.

Ice service stations were small buildings that stored and sold ice. These buildings might be in small towns that did not have ice plants. They might also be found in larger communities near homes and businesses rather than in industrial areas. They had fewer vaults that were smaller than those in ice plants and did not process ice or provide cold storage. Ice service stations had a drive-up bay, from which vehicular traffic, including ice delivery trucks, could pick up ice. Like ice plants, service stations usually reflected popular contemporaneous architectural styles. 

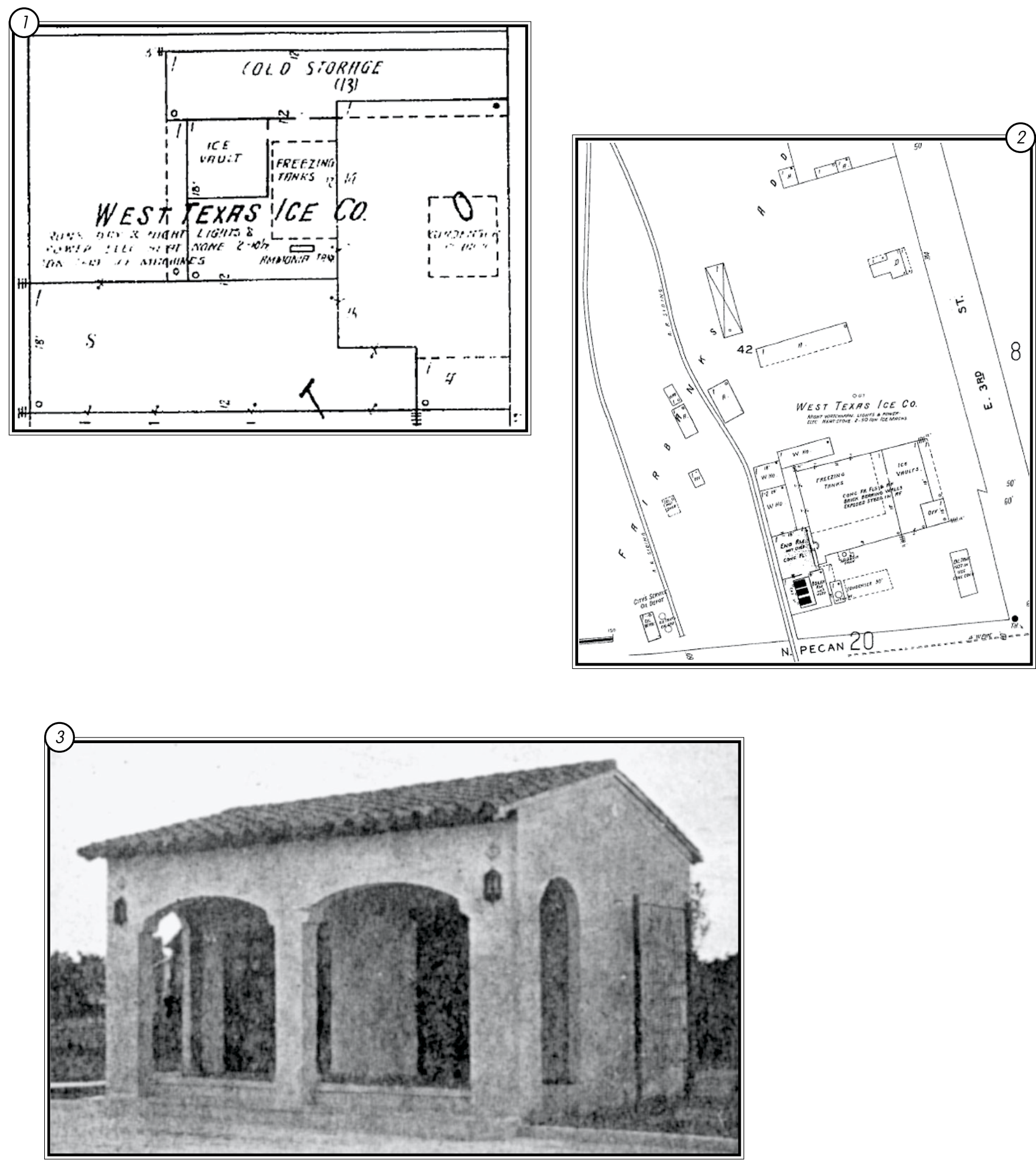

$1 \quad$ Near downtown San Angelo, the West Texas Ice Company had a large ice plant by 1927 that-in addition to the necessary freezing tanks, ammonia tanks, and ice vault - had a huge cold storage area.

2 Away from downtown San Angelo, the West Texas Ice Company had an even larger plant with two 50-ton ice machines. Railroad sidings allowed the company to transport ice from this plant to other communities.

3 Ice service stations like this one in San Angelo sold ice to consumers. The building evokes characteristics of Spanish Colonial Revival design with its smooth surface of stucco, arched openings, tile roof, and stylized light fixtures. 


\section{ICE SERVICE}
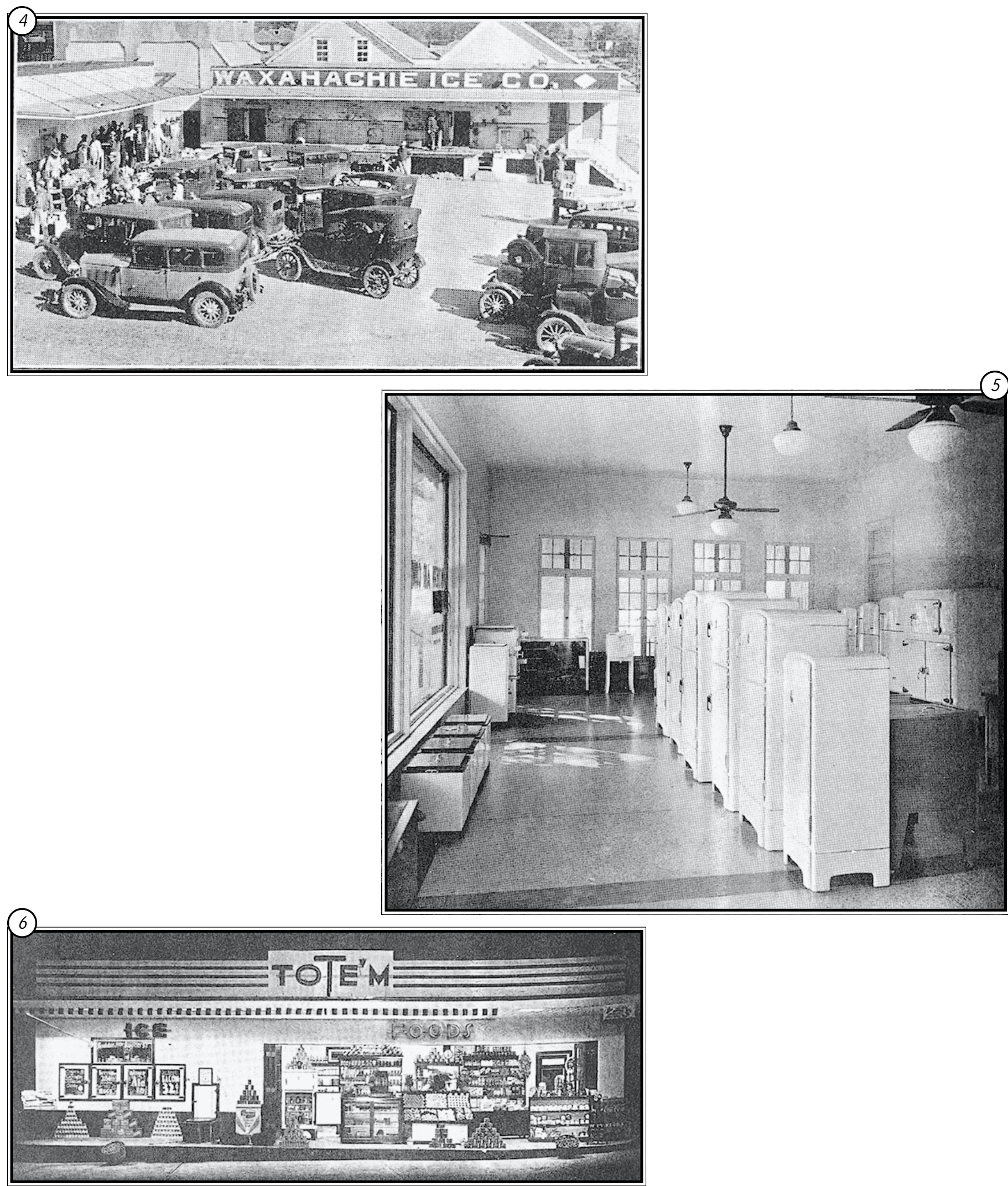

$4 \quad$ Families without home refrigeration could pay ice plants for cold storage of meat. The Waxahachie Ice Company offered this sideline in 1930.

5 By 1938, refrigerator sales was a sideline for the City Ice Delivery Company in Dallas.

6 A natural progression for ice service stations was to evolve into convenience stores like this Tote'm Store that the Southland Ice Company operated in 1938. 


\section{BotTlung Works}

\section{Character-defining Features}

- Masonry building

- Rectangular plan

- Flat roof

- Central public entryway on main façade

- Signage identifying company

- Multiple-pane fenestration forms a window-wall

- Loading platforms

- Sheds and storage buildings

- Truck parking area

- Garage bays

\section{Principal Subtypes}

\section{Small Town-}

- One-part commercial-block form

- Interior space for production and stock storage

> Large parking area

\section{Urban-}

- Factory configuration, or two-part commercial-block form

- Two or more stories

- First level for truck docks and loading platforms

- Upper levels for production and stock storage

- "Drive-thru" loading area

\section{Comments}

Many small towns in Texas had bottling plants, especially for Coca-Cola or Dr. Pepper products. A few towns had bottling works that were not associated with any particular product. Window-walls allowed clients and visitors an opportunity to see the bottling process in motion. Facilities constructed up to the 1920 s exhibit modest stylistic influences, most often classically inspired symmetrical fenestration patterns, emphasized cornice and frieze lines, and prominent central entryways. Mid-twentieth-century bottling plants constructed in the 1920 s and 1930s may exhibit Art Deco or Art Moderne attributes. Plants constructed in the mid-twentieth century likely employ International Style design principles.

Small-town bottling works are typically one-part commercial-block buildings. The surrounding complex includes a large parking area for delivery vehicles, garage bays for their maintenance, and loading docks. Although their shapes differ, production and loading areas each require about the same amount of space. Smalltown bottling works are not necessarily near railroad tracks, since delivery trucks carry products from the plant to local businesses and outlying communities.

Bottling plants in urban centers are usually two or more stories and are configured as a factory building or a two-part commerical-block form. The entire first level is devoted to truck docks and loading platforms, and upper levels are used for production and storage. The loading area is substantially larger than that used for production, and is configured to be "drive-thru." 

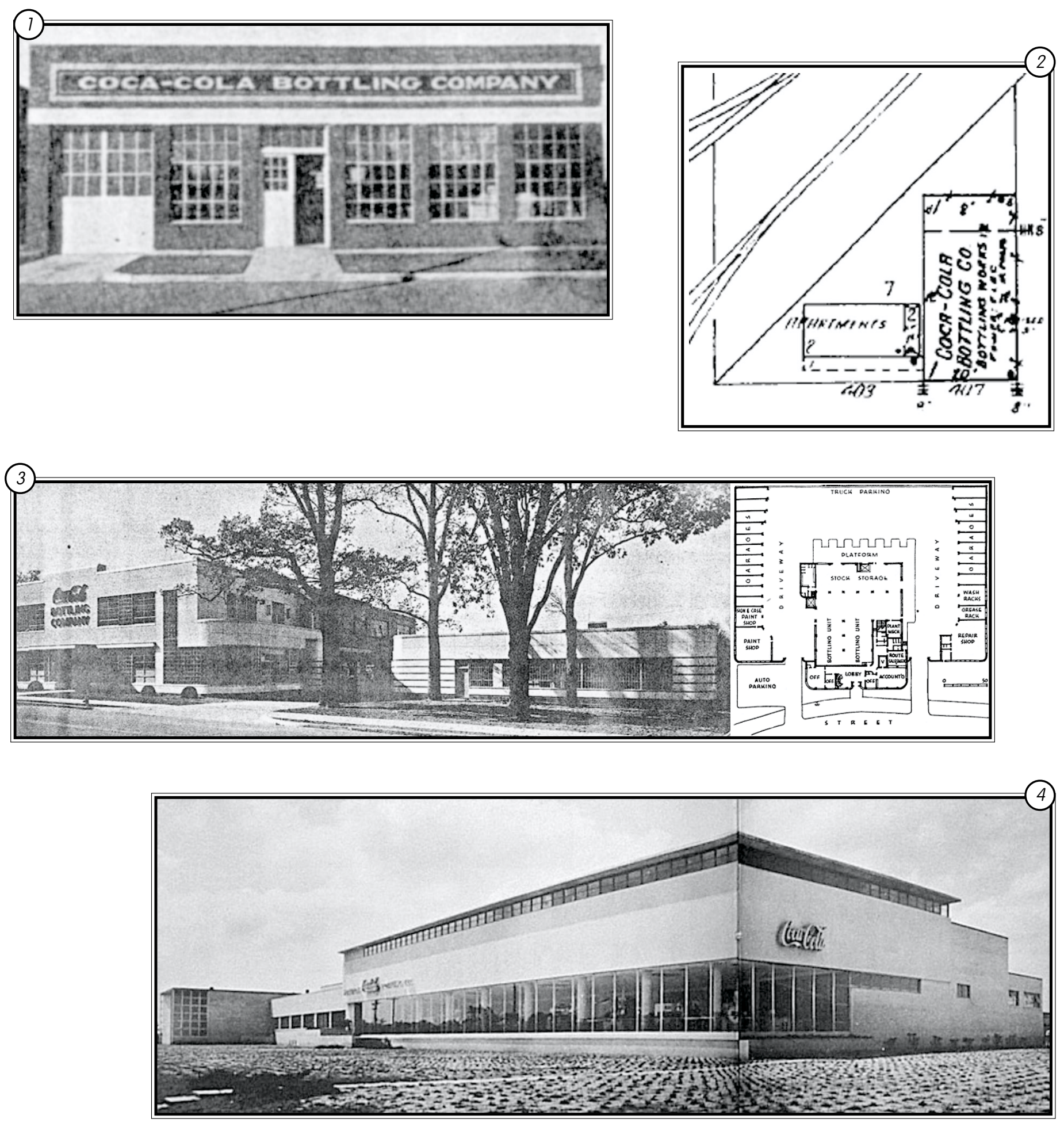

1 The ca. 1922 Coca-Cola Bottling Company in Stamford was a typical small-town bottling company. Multiple-pane fenestration serves as a window-wall for passersby to view the bottling process. A truck bay and driveway to one side allowed for "drive-thru" access.

2 The Stamford Coca-Cola Bottling Company had a loading platform at the rear in 1930.

3 Art Moderne stylistic influences are exhibited in the asymmetrical façade, horizontal emphasis, curved corners, and glassblock windows that wrap around a 1941 Coca-Cola Bottling Company prototype built around the country. The layout shows how interior space was organized on the first level.

4 Smooth surfaces, asymmetry, multiple-level roofs, and ribbons of windows employed in this design are typical of International Style at the Coca-Cola Bottling Company in Houston in the late 1940s. The tall first-floor windows display the bottling works to visitors. 


\section{For FuRTHER RefERENCE}

Readers seeking additional information about industrial property types may find several helpful sources for understanding each industry addressed in this field guide and related buildings and structures. A handful of general studies are included that provide practical knowledge about industrial properties and related architectural styles. Betsy H. Bradley's The Works: The Industrial Architecture of the United States (Oxford University Press, New York, 1999) concentrates on manufacturing establishments, but offers an excellent glossary of terms that has much broader applications. Ann Durkin Keating's Invisible Networks: Exploring the History of Local Utilities and Public Works (Exploring Community History Series, eds. David E. Kyvig and Myron A. Marty, Krieger Publishing Company, Malabar, Florida, 1994) provides guidance on documenting local historical aspects of utility companies. A thoughtful study by Robert B. Gordon and Patrick M. Malone, The Texture of Industry: An Archaeological View of the Industrialization of North America (Oxford University Press, New York, 1994), offers an overview of industrial complexes from an archeological perspective. Carole Rifkind's book A Field Guide to American Architecture (New American Library, New York, 1980) has comments and drawings pertinent to industrial property types, although she focuses on the eastern United States. Two other important books are those by Richard Longstreth, The Buildings of Main Street: A Guide to American Commercial Architecture (AltaMira Press for the American Association for State and Local History, Nashville, updated edition 2000, original published in 1987), and Virginia McAlester and Lee McAlester A Field Guide to American Houses (Alfred A. Knopf, New York, updated edition 1997, original published in 1984). Although each of these guides concentrates on property types other than those related to industry, they offer relevant insight to analyzing form and style.

Information about the petroleum and natural gas industries is voluminous. One study that takes a global approach, but concentrates strictly on drilling practices, is J. E. Brantly's History of Oil Well Drilling IGulf Publishing Company, Houston, 1971). Two other comprehensive studies are Petroleum Encyclopedia: Done in Oil(The Ranger Press, Inc., New York, 1941) by David D. Leven and The American Petroleum Industry: The Age of Energy, 18991959 by Harold F. Williamson, Ralph L. Andreano, Arnold R. Daum, and Gilbert C. Klose (Northwestern University Press, Evanston, 1963). Studies on the oil industry that are specific to Texas include Wayne Gard's The First 100 Years of Texas Oil \& Gas (Mid-Continent Oil and Gas Association, 1966), Thelma Johnson et al.'s The Spindle Top Oil Field: A History of Its Discovery and Development (n.p., n.p., 1927, available at the Perry-Castañeda Library, University of Texas, Austin), Richard R. Moore's "The Impact of the Oil Industry in West Texas" (M.A. Thesis, Texas Tech University, Lubbock, 1965), and Walter Rundell's Early Texas Oil: A Photographic History, 1866-1936 (Texas

A\&M University Press, College Station, 1977) and Oil in West Texas and New Mexico: A Pictorial History of the Permian Basin (Texas A\&M University Press for the Permian Basin Petroleum Museum, Library and Hall of Fame in Midland, College Station, 1982). Perhaps the most important books on the Texas oil industry are those of Diana 
Davids Olien and Roger M. Olien, Oil Booms: Social Change in Five Texas Towns (University of Nebraska Press, Lincoln, 1982), Wildcatters: Texas Independent Oil Men (Texas Monthly Press, Austin, 1984), Life in the Oil Fields (Texas Monthly Press, Austin, 1986), and their latest book Oil in Texas: The Gusher Age, 1895-1945 (University of Texas Press, Austin, 2002).

Several publications relate the history of a specific oil company. Chief among these are Henrietta M. Larson's and Kenneth Wiggins Porter's History of Humble Oil \& Refining Company: A Study in Industrial Growth (Harper \& Brothers Publishers, New York, 1959), Louis C. Arnett's "The Humble Oil \& Refining Company of Texas" (M.A. Thesis, University of Texas, Austin, 1924), and Continental Oil Company's self-published Conoco: The First One Hundred Years: Building on the Past for the Future ISpecial Marketing Division, Dell Publishing Company, Inc., New York, 1975). Companies also published in-house newsletters that are largely unmined. These include The Humble Way, The Benedum-Trees Loose Leaf, and Magnolia News, among others.

Other sources are essential to understanding the petroleum and natural gas industry. Two publications, The Oil and Gas Journal and The Oil Weekly, offer articles on all aspects of the industry, plus manufacturers' advertisements that reveal additional information about technology, buildings, and structures related to petroleum and natural gas. The Oil Weekly also published annually the Composite Catalog of Oil Field and Pipe Line Equipmentbeginning in 1929. The Petroleum Museum, in Midland, has extensive photographic collections, although many of the items are not cataloged. The personal collection of William Osborn, in Austin, includes many images of buildings and structures.

Two broad studies of the grain industry are William C. Edgar's The Story of a Grain of Wheat(D. Appleton and Company, New York, 1925) and Herman Steen's Flour Milling in America (T. S. Denison \& Company, Inc., Minneapolis, 1963). Edgar takes a world history approach to the industry and discusses grain in ancient times, as well as in contemporaneous Britain and Argentina. He also reflects on the wheat fields of the future and the progress of milling in America. Steen focuses on mills in the United States from their East Coast beginnings to the monopolies of the Midwest. Most useful is his brief review of milling company histories, by state, in which he devotes 17 pages to Texas companies in Amarillo, Dallas, Denton, Fort Worth, Gainesville, Galveston, Greenville, Houston, McKinney, New Braunfels, Paris, Plainview, San Antonio, Seguin, Sherman, Vernon, Waco, and Wichita Falls.

Four other studies are particularly useful for understanding properties related to the grain industry because they offer specific descriptive information, corresponding illustrations, and photographs. George O. Carney authored "Grain Storage and Processing Facilities in Western Oklahoma" (Oklahoma Historical Society, Oklahoma City, 1999), which offers detailed descriptive information about grain processing and storage facilities and their respective constituent parts. He succinctly describes milling processes for the layperson's easy understanding. Although Mills of Yesteryear by A. T. Jackson (Texas Western Press, El Paso, 1971) is scant on interpretation, it presents several images of nineteenth century mill properties in Texas. Frank Gohlke and John C. Hudson, provide two pensive essays on grain elevators in Gohlke's Measure of Emptiness: Grain Elevators in the American Landscape (Creating the North American Landscape Series, George F. Thompson, ed. Johns Hopkins University Press, Baltimore, 1992). But a picture says a thousand words, and Gohlke's photographs of grain elevators, mostly in Texas, portray dramatic images of these massive functional structures. An older volume, The Design of Walls, Bins, and Grain Elevators (The Engineering News Publishing Company, New York, 1911, second edition), by Milo S. Ketchum, provides detail and line drawings. Ketchum discusses the physics of grain storage with theories and algebraic methods. He reports the problems of retaining walls and experiments for improving them. More importantly, he presents all types of bins and elevators built in a variety of designs and materials.

Numerous sources address all aspects of the cotton industry. General studies are helpful to understanding cotton production and ginning. A few useful older publications are Anderson, Clayton \& Co.'s Texas Cotton from Seed to Mill (Anderson, Clayton \& Co., Houston, 1937), Henry Julius Boehm's "Texas Cotton Co-operative Association" (M.A. Thesis, University of Texas, Austin, 1935), H. M. Eliot's Farmers' Cooperative Gins in Texas (Division of 
Farm and Ranch Economics, Texas Agricultural Experiment Station, Texas A\&M University, College Station, 1920), and the U.S. Bureau of Agricultural Economics's Texas Cotton: Estimated Acreage, Yield, and Production, 19281937, by Counties (Office of the Agricultural Statistician, Austin, 1939). A few works offer regional insights, such as "The Quality, Costs and Economic Aspects of West Texas Cotton Ginning" by William E. Franklin Jr. IM.A. Thesis, Texas Tech University, Lubbock, 1950), "A Survey of Cotton Production in Northwest and South Texas" by Albert Brice Taylor (M.A. Thesis, University of Texas, Austin, n.d.), and Practices and Costs of Cotton-Gin Operation in North-Central Texas, 1924-1925 by James S. Hathcock (Technical Bulletin 13, Division of Cooperative Marketing, Bureau of Agricultural Economics, U.S. Department of Agriculture, Washington, D.C., 1927).

Analyses that examine cotton gins and ginning can be either broad or narrowly focused. Works that are encompassing include Cotton Ginning Systems in the United States and Auxiliary Developments by Charles A. Bennett (Cotton Ginner's Journal and The Cotton Gin and Oil Mill Press, Dallas, 1962), and Bale o' Cotton: The Mechanical Art of Ginning by Karen Gerhardt Britton (Texas A\&M University Press, College Station, 1992). Two important theses are those of Raymond E. White and Jim Chien-Sheng, who respectively wrote "The History of the Texas Cotton Ginning Industry, 1822-1957" (M.A. Thesis, University of Texas, Austin, 1957) and "A Study of the Cotton Gin and lts Operation" (M.A. Thesis, Texas Tech University, Lubbock, 1950). On a more personal level, A. L. Vandergriff contributed his singular Ginning Cotton: An Entrepreneur's Study (Texas Tech University Press, Lubbock, 1997), which chronicles his life experiences as a ginner. In addition, journals published for the ginning industry, provide much in the way of details about operations, buildings, structures, and equipment; especially helpful is The Cotton Ginners' Journal, published by the Texas Cotton Ginners' Association in Dallas. Detailed interpretations of cotton gins include Michelle Sharon Gayle Cluck Hainze's "Analysis of Cotton Gin Buildings in the South Plains Region" (M.A. Thesis, Texas Tech University, Lubbock, 1999) and James Ricky Lewis's "Texas Cotton Gin House Architecture" (M.A. Thesis, The University of Texas at Austin, 1987).

Cotton gin manufacturers often published materials. These might include contemporaneous catalogs, like the Munger Improved Cotton Machine Manufacturing Company's Catalogue and Price List (Dallas Litho Job Print, Dallas, 1889), or promotional materials, like The Murray Company, Its History, Growth, Present Extent, Facilities and Service, and Its Products by the Murray Company (Bulletin No. 1, Dallas, 1929). Companies also published corporate histories, such as the book by Algernon L. Smith, The Continental Gin Company and Its Fifty-Two Years of Service (Continental Gin Company, [Birmingham], 1952).

Once subsidiary to cotton ginning, the cottonseed crushing aspect of the industry became increasingly important in the twentieth century. Several valuable works on this topic include A. B. Cox's The Cottonseed Crushing Industry of Texas in Its National Setting (The Cotton Research Committee of Texas, University of Texas, Austin, 1949), William N. Stokes Jr.'s Oil Mill on the Texas Plains: A Study in Agricultural Cooperation (Texas A\&M University Press, College Station, 1979), and Lynette Wrenn's Cinderella of the New South: A History of the Cotton Seed Industry, 1855-1955 (University of Tennessee Press, Knoxville, 1995). Publications, such as Storing of Seed Cotton as an Aid to More Efficient Ginning and Marketing by J. M. Ward, W. E. Paulson, and D. L. Jones (Texas Agricultural Experiment Station, Bulletin 765, College Station, 1953), offer specific information about storage facilities. The industry had two important journals, The Cotton Oil Press, which was published from 1917 to 1935, and The Cotton Gin and Oil Mill Press, begun in 1900 and still in publication. Available at the Southwest Collection at Texas Tech University are the appraisal books of the Hill County Oil Company. These provide raw data on the company's holdings between 1918 and 1931, accounting for each component of the several mills and related equipment, from presses to bins to buildings to vehicles, owned and acquired during these years.

The utilities and services industries encompasses several entities, including electric, water, telephone, ice service, and bottling works. Several publications are informative about particular electric companies. Vance Gillmore's And the Work Was Made Less (Texas Electric Service Company, [Fort Worth], 1976), Robert L. Johnson's Texas Power \& Light Company, 1912-1972 (Texas Power \& Light Company, [Dallas], 1973), Bennett L. Smith's Com- 
munity Public Service Company: Its History, People, and Places (Bennett L. Smith, Fort Worth, 1975), and the Southwestern Public Service Company's publication The Southwesterner, each offer insight into specific electric companies. In addition, the Central and South West Corporation has papers that cover the 1950s in the Southwest Collection at Texas Tech University in Lubbock.

Telephone companies often have published histories. Useful volumes include W. M. Gilker's compilation, Southwestern Bell Telephone Company, Dallas Telephone History, 1881-1963 (Southwestern Bell Telephone Company, Dallas, 1963), Jerry F. Hall's edited Hello, Texas: A History of Telephony in the Lone Star State (Texas Telephone Association, Austin, 1990), Larry Johnson's The Heritage of Time: The People and Times of GTE Southwest, 1876-1988 (Newsfoto Publishing Co., San Angelo, 1990), and David G. Park's Good Connections: A Century of Service by the Men \& Women of Southwestern Bell (Southwestern Bell Telephone Company, St. Louis, 1984).

Ice services have been well studied and numerous publications provide excellent documentation of the industry. A few historical pieces of note are J. J. Cosgrove's Sanitary Refrigeration and Ice Making IStandard Sanitary Mfg. Co., Pittsburgh, 1914), James Baker Marley's "An Analysis of Ice Delivery Methods with Particular Attention Being Given to Practices of the Texas Industry" (MBA Thesis, University of Texas, Austin, 1925), and articles in the Southwestern Ice Manufacturers' Association Bulletin (Southwestern Ice Manufacturers' Association 1934-1952). Helpful syntheses of the ice industry up through the early twentieth century are The American Ice Harvests: A Historical Study in Technology, 1800-1918 by Richard Osborn Cummings (University of California Press, Berkeley, 1949) and America's Icemen: An Illustrative History of the United States Natural Ice Industry, 1665-1925 (Jobeco Books, Humble, Texas, 1984).

Few sources are available on water service. The most useful was T. Lindsay Baker's Building the Lone Star State: An Illustrated Guide to Historic Sites (No. 23: The Centennial Series of The Association of Former Students, Texas A\&M University, Texas A\&M University Press, 1986). Baker reviews numerous types of properties, including waterworks and sewage plants. Simon W. Freese and Deborah Lightfoot Sizemore prepared A Century in the Works: Freese and Nichols Consulting Engineers, 1894-1994 (Texas A\&M University Press, College Station, 1994). This volume documents the firm's work, which included several waterworks, filtration plants and sewage treatment plants. Another publication that covered several topics, including water service, is Greater Dallas Illustrated by the American Illustrating Company (The American Illustrating Company, 1908; reprint Friends of the Dallas Public Library, Dallas, 1992). A large volume that the Public Works Administration put together is exceptionally helpful to understanding properties constructed from 1933 to 1939. C. W. Short and R. Stanley Brown co-authored Public Buildings: A Survey of Architecture of Projects Constructed by Federal and Other Governmental Bodies between the Years 1933 and 1939 (Government Printing Office, Washington, D.C., 1939). The book is national in scope, but offers several Texas examples of utilities properties like sewage facilities and waterworks.

Likewise, information on bottling works was relatively scarce. The best available source was Industrial Buildings; The Architectural Record of a Decade compiled by Kenneth Reid (F. W. Dodge Corp. for Architectural Record, New York, 1951). A later publication that offered some additional information was Buildings for Industry prepared by Architectural Record (F. W. Dodge Corp. for Architectural Record, New York, 1957).

In cases like water service and bottling works, where source materials are limited, several more general works may be helpful. The internet has many useful resources, such as the Sanborn Map Company's fire insurance maps, and a wealth of articles that are available by searching various terms. An excellent publication is Out of the Dreams of Yesterday: West Texas Utilities Company, which the company authored and published in 1927. This promotional brochure portrays not only the company's own utilities establishments, but also highlights those of competitors and of other industries, including petroleum and natural gas, grain, and cotton. It is available at The Center for American History at The University of Texas at Austin. 


\section{IMAGE CReDits}

Abbreviated citations appear below for those sources that have full citations in "For Further Reference." For all other sources, full citations appear initially and subsequent entries are abbreviated.

\section{COVER}

Texas Department of Transportation, photograph by H. Gregory Quinn, 2001

Texas Department of Transportation, Haskell County Highway Map, 1936

\section{Petroleum and Natural Gas Property Types (p. 1)}

The Oil and Gas Journal, Golden Anniversary Number, Petroleum Publishing Company, Tulsa, May 1951:53

\section{Bulk Terminal Plants (pp. 4-5)}

1 Osborn Collection, photographer unknown, ca. 1925

2 Sanborn Map Company, Merkel, Taylor County, 1925:6

3 Prewitt and Associates, Inc., photograph by the author, 2002

4 Sanborn Map Company, Spur, Dickens County, 1927-1936:4

5 Don E. Morrison, "Spill Prevention and Countermeasure Plan for Spur, Texas, Bulk Plant," Osborn Collection, 1978

6 Osborn Collection, photograph by William Osborn, 1998

7 The Humble Way, "How A Products Terminal Operates," January-February 1951:7

\section{Tanks and Tank Farms (pp. 7-8)}

1 Rundell, Early Texas Oil, 1977:129

2 Petroleum Museum Collection, Storage Tank and Catwalk, n.d., 75-112.11

3 The Oil Weekly, Composite Catalog, 1929:108

4 Williamson et al., The American Petroleum Industry, 1963:816

5 Larson and Porter, History of Humble Oil \& Refining Company, 1959:between 230-31

6 The Oil and Gas Journal, Golden Anniversary Number, May 1951:414

\section{Refineries (pp. 10-11)}

1 Continental Oil Company, Conoco, 1975:84-85

2 Larson and Porter, History of Humble Oil \& Refining Company, 1959:between 230-31

3 Leven, Petroleum Encyclopedia, 1941:541

4 The Oil and Gas Journal, Golden Anniversary Number, May 1951:162

5 The Oil and Gas Journal, Golden Anniversary Number, May 1951:314

6 The Oil and Gas Journal, Golden Anniversary Number, May 1951:314

7 The Oil and Gas Journal, Golden Anniversary Number, May 1951:314

8 The Oil Weekly, Composite Catalog, 1946:718

\section{Natural Gas Plants (p. 13)}

1 Rundell, Oil in West Texas and New Mexico, 1982:30

2 The Oil and Gas Journal, Golden Anniversary Number, May 1951:375

3 The Oil and Gas Journal, Golden Anniversary Number, May 1951:392

4 The Oil and Gas Journal, Golden Anniversary Number, May 1951:375

5 Rundell, Oil in West Texas and New Mexico, 1982:159

\section{Pipelines (p. 15)}

1 The Oil and Gas Journal, Golden Anniversary Number, May 1951:413

2 Leven, Petroleum Encyclopedia, 1941:516

3 The Oil and Gas Journal, Golden Anniversary Number, May 1951:160

4 The Oil and Gas Journal, Golden Anniversary Number, May 1951:421 


\section{Derricks and Drill Rigs (pp. 16-17)}

1 The Oil and Gas Journal, Golden Anniversary Number, May 1951:225

2 Gordon and Malone, The Texture of Ind ustry, 1994:288

3 The Oil Weekly, Composite Catalog, 1934:n.p.

4 The Oil Weekly, Composite Catalog, 1934:237

5 The Oil and Gas Journal, Golden Anniversary Number, May 1951:106

\section{Pump Houses and Pump Stations (pp. 18-19)}

1 The Oil and Gas Journal, Golden Anniversary Number, May 1951:140

2 West Texas Utilities Company, Out of the Dreams of Yesterday, 1927:22

3 The Oil Weekly, Composite Catalog, 1946:718

4 The Oil Weekly, Composite Catalog, 1946:1,858

\section{Pump Units (p. 21)}

$1 \quad$ Rundell, Oil in West Texas and New Mexico, 1982:58

2 The International Derrick \& Equipment Co. advertisement, The Oil And Gas Journal, February 6, 1930:77

3 The Oil Weekly, Composite Catalog, 1934:n.p.

4 The Oil Weekly, Composite Catalog, 1934:238

\section{Power Houses and Boiler Houses (p. 23)}

1 Casey-Hedges advertisement, The Oil and Gas Journal, February 27, 1920:38

2 The Oil Weekly, Composite Catalog, 1934:n.p.

3 The Oil Weekly, Composite Catalog, 1934:237

4 The Oil Weekly, Composite Catalog, 1934:125

\section{Separators and Metering Stations (p. 25)}

1 Rundell, Oil in West Texas and New Mexico, 1982:71

2 Rundell, Oil in West Texas and New Mexico, 1982:117

3 Nicholas P. Trentacoste, George R. Bierman, and James Cunningham, Spill Prevention, Control and Countermeasure Practices at Small Petroleum Facilities, Interagency Energy/Environment R\&D Program Report, Industrial Environmental Research Laboratory, Office of Research and Development, U.S. Environmental Protection Agency, Cincinnati, 1980:24

4 Trentacoste et al., Spill Prevention, Control and Countermeasure Practices, 1980:27

\section{Supply Depots (p. 27)}

1 Frick-Reid Supply Company advertisement, The Oil and Gas Journal, January 9, 1920:37

2 Sanborn Map Company, Electra, Wichita County, 1919:9

3 The Oil and Gas Journal, Golden Anniversary Number, May 1951:62

4 Rundell, Oil in West Texas and New Mexico, 1982:110

5 Osborn Collection, photograph by William Osborn, 1998

\section{Warehouses (p. 29)}

1 The Oil Weekly, Composite Catalog, 1929:29

2 The Oil Weekly, Composite Catalog, 1929:29

3 The Oil Weekly, Composite Catalog, 1946:716

4 The Oil Weekly, Composite Catalog, 1946:717

\section{Grain Property Types (p. 31)}

Gohlke, Measure of Emptiness, 1992:43

\section{Storage Complexes (pp. 33-34)}

1 Ketchum, The Design of Walls, Bins, and Grain Elevators, 1911:284

2 Ketchum, The Design of Walls, Bins, and Grain Elevators, 1911:284

3 Ketchum, The Design of Walls, Bins, and Grain Elevators, 1911:361

4 Ketchum, The Design of Walls, Bins, and Grain Elevators, 1911:302

5 Sanborn Map Company, Haskell, Haskell County, 1913:1

6 Gohlke, Measure of Emptiness, 1992:41

7 Gohlke, Measure of Emptiness, 1992:76

\section{Processing Complexes (pp. 36-37)}

1 Sanborn Map Company, Haskell, Haskell County, 1913:1

2 West Texas Utilities Company, Out of the Dreams of Yesterday, 1927:27

3 Jackson, Mills of Yesteryear, 1971:between 82-83

4 West Texas Utilities Company, Out of the Dreams of Yesterday, 1927:27 
Sanborn Map Company, Munday, Knox County, 1925:2

West Texas Utilities Company, Out of the Dreams of Yesterday, 1927:27

Prewitt and Associates, Inc., photograph by the author, 2002

Prewitt and Associates, Inc., photograph by the author, 2002

\section{Auxiliary Buildings (p. 39)}

1 West Texas Utilities Company, Out of the Dreams of Yesterday, 1927:27

2 Gohlke, Measure of Emptiness, 1992:45

3 Sanborn Map Company, Crowell, Foard County, 1921:10

4 Gohlke, Measure of Emptiness, 1992:69

\section{Storage Bins (pp. 41-42)}

1 Gohlke, Measure of Emptiness, 1992:39

2 Ketchum, The Design of Walls, Bins, and Grain Elevators, 1911:301

3 Ketchum, The Design of Walls, Bins, and Grain Elevators, 1911:360

4 Ketchum, The Design of Walls, Bins, and Grain Elevators, 1911:364

5 Ketchum, The Design of Walls, Bins, and Grain Elevators, 1911:304

6 Ketchum, The Design of Walls, Bins, and Grain Elevators, 1911:384

7 Ketchum, The Design of Walls, Bins, and Grain Elevators, 1911:302

8 Gohlke, Measure of Emptiness, 1992:37

\section{Cotton Property Types (p. 43)}

Anderson, Clayton \& Company, Texas Cotton from Seed to Mill, 1937:Figure 68

\section{Gin Complexes (pp. 46-47)}

1 Anderson, Clayton \& Company, Texas Cotton from Seed to Mill, 1937:Figure 68

2 Britton, Bale o' Cotton, 1992:70

3 Britton, Bale o' Cotton, 1992:79-80

4 Britton, Bale o' Cotton, 1992:79-80

5 Arthur J. Earl, "Buildings of Brick for the Ginning Industry," The Cotton Ginners' Journal, vol. 1, no. 4, January 1930:5

6 Hathcock, Practices and Costs of Cotton-Gin Operation in North-Central Texas, 1927:14

7 Hainze, "Analysis of Cotton Gin Buildings in the South Plains Region," 1999:58

8 Hainze, "Analysis of Cotton Gin Buildings in the South Plains Region," 1999:58

9 West Texas Utilities Company, Out of the Dreams of Yesterday, 1927:17

10 Sanborn Map Company, Winters, Runnels County, 1925:4

\section{Cottonseed Oil Mills (pp. 49-50)}

1 Hill County Cotton Oil Co., Appraisal Books, 1918-1931

2 Hill County Cotton Oil Co., Appraisal Books, 1918-1931

3 Hill County Cotton Oil Co., Appraisal Books, 1918-1931

4 Hill County Cotton Oil Co., Appraisal Books, 1918-1931

5 West Texas Utilities, Out of the Dreams of Yesterday, 1927:18

6 Sanborn Map Company, Winters, Runnels County, 1925:5

7 Stokes, Oil Mill on the Texas Plains, 1979:following 78

\section{Cotton Houses and Warehouses (pp. 52-53)}

1 Munger Improved Cotton Machine Manufacturing Company, Catalogue and Price List, 1889:42-43

2 Louis Tuffley Ellis, "The Cotton Compress Industry in Texas," Ph.D. dissertation, University of Texas, Austin, 1964:117

3 West Texas Utilities Company, Out of the Dreams of Yesterday, 1927:19

4 Bennett, Cotton Ginning Systems, 1962:24

5 Sanborn Map Company, Stamford, Jones County, 1930:12

6 West Texas Utilities Company, Out of the Dreams of Yesterday, 1927:18

7 Anderson, Clayton \& Company, Texas Cotton from Seed to Mill, 1937:Figure 105

8 Anderson, Clayton \& Company, Texas Cotton from Seed to Mill, 1937:Figure 106

\section{Seed Storage Facilities (pp. 54-55)}

1 Munger Improved Cotton Machine Manufacturing Company, Catalogue and Price List, 1889:n.p.

2 Bennett, Cotton Ginning Systems, 1962:28

3 Bennett, Cotton Ginning Systems, 1962:29

4 Hill County Cotton Oil Co., Appraisal Books, 1918-1931

5 Hill County Cotton Oil Co., Appraisal Books, 1918-1931

6 Stokes, Oil Mill on the Texas Plains, 1979:following 78

7 Austin Brothers advertisement, The Cotton Gin and Oil Mill Press, vol. 52, no. 14, July 7, 1951:30 


\section{Trash Collection Facilities (pp. 56-57)}

1 Earl, "Buildings of Brick for the Ginning Industry," January 1930:23

2 Earl, "Buildings of Brick for the Ginning Industry," January 1930:23

3 Portland Cement Association, "Concrete Masonry Cotton Burr Burner," Concrete Information FB6, Farm Bureau, Portland Cement Association, 1950:1

4 Bennett, Cotton Ginning Systems, 1962:27

5 Bennett, Cotton Ginning Systems, 1962:27

\section{Utilities and Services Property Types (p. 59)}

Gillmore, And Work Was Made Less, 1976:94

\section{Electric Utilities (pp. 62-64)}

1 Johnson, Texas Power \& Light Company, 1973:31

2 Johnson, Texas Power \& Light Company, 1973:31

3 West Texas Utilities Company, Out of the Dreams of Yesterday, 1927:7

4 Gillmore, And Work Was Made Less, 1976:137

5 Johnson, Texas Power \& Light Company, 1973:112

6 West Texas Utilities Company, Out of the Dreams of Yesterday, 1927:4

7 Johnson, Texas Power \& Light Company, 1973:54

8 West Texas Utilities Company, Out of the Dreams of Yesterday, 1927:11

9 West Texas Utilities Company, Out of the Dreams of Yesterday, 1927:5

10 West Texas Utilities Company, Out of the Dreams of Yesterday, 1927:9

11 "Amarillo Office," The Southwesterner, vol. 1, no. 1:11, July-August, 1944:11

\section{Water Utilities (pp. 66-68)}

Freese and Sizemore, A Century in the Works, 1994:25

Sanborn Map Company, Graham, Young County, 1927:9

West Texas Utilities Company, Out of the Dreams of Yesterday, 1927:37

West Texas Utilities Company, Out of the Dreams of Yesterday, 1927:37

Sanborn Map Company, Denton, Denton County, 1926:4

Sanborn Map Company, Denton, Denton County, 1926-1949:4

Freese and Sizemore, A Century in the Works, 1994:251

8 Karl W. Kibler and Karen M. Gardner, Archeological Survey and National Register Testing at 41BX377, Camp Bullis Military Reservation, Bexar and Comal Counties, Texas, Reports of Investigations, No. 101, U.S. Army Corps of Engineers, Fort Worth District, Prewitt and Associates, Inc., Austin, 1997:20

9 Baker, Building the Lone Star State, 1986:228

10 Freese and Sizemore, A Century in the Works, 1994:153

11 Freese and Sizemore, A Century in the Works, 1994:104

\section{Telephone Utilities (pp. 70-71)}

1 Johnson, The Heritage of Time, 1990:80

2 Johnson, The Heritage of Time, 1990:151

3 Johnson, The Heritage of Time, 1990:223

4 Keating, Invisible Networks, 1994:81

\section{Ice Service (pp. 73-74)}

1 Sanborn Map Company, San Angelo, Tom Green County, 1927:3

2 Sanborn Map Company, San Angelo, Tom Green County, 1927:20

3 West Texas Utilities Company, Out of the Dreams of Yesterday, 1927:15

4 "Farmers Bringing Meat To Be Cured and Stored Give R. H. Davis, Waxahachie Ice Company a Busy Day," Southwestern Ice Manufacturers' Association Bulletin, No. 102, January 1935:9

5 "Main Office Building and Display Room of the City Ice Delivery Company, Dallas, Texas," Southwestern Ice Manufacturers' Association Bulletin, No. 126, May 1938:4

6 "One of the Attractive Community Ice Station Tote'm Stores Operated in Dallas and Fort Worth by the Southland Ice Company," Southwestern Ice Manufacturers' Association Bulletin, No. 126, May 1938:10

\section{Bottling Works (p. 76)}

1 West Texas Utilities Company, Out of the Dreams of Yesterday, 1927:45

2 Sanborn Map Company, Stamford, Jones County 1930:12

3 Reid, Industrial Buildings, 1951:434

4 Architectural Record, Buildings for Industry, 1957:132-33 